This document was prepared in conjunction with work accomplished under Contract No. DE-AC09-96SR18500 with the U.S. Department of Energy.

This work was prepared under an agreement with and funded by the U.S. Government. Neither the U. S. Government or its employees, nor any of its contractors, subcontractors or their employees, makes any express or implied: 1 . warranty or assumes any legal liability for the accuracy, completeness, or for the use or results of such use of any information, product, or process disclosed; or 2 . representation that such use or results of such use would not infringe privately owned rights; or 3 . endorsement or recommendation of any specifically identified commercial product, process, or service. Any views and opinions of authors expressed in this work do not necessarily state or reflect those of the United States Government, or its contractors, or subcontractors. 


\section{BIOTIC INTEGRITY OF STREAMS IN THE SAVANNAH RIVER SITE INTEGRATOR OPERABLE UNITS, 1996 to 2003}

Michael H. Paller

Savannah River Technology Center

Westinghouse Savannah River Company

Susan A. Dyer

Site Geotechnical Services

Westinghouse Savannah River Company

Prepared for the U.S. Department of Energy under contract no. DE-AC09-89SR18035 
WSRC-TR-2003-00149

Rev. 0

March 27, 2003

\section{Table of Contents}

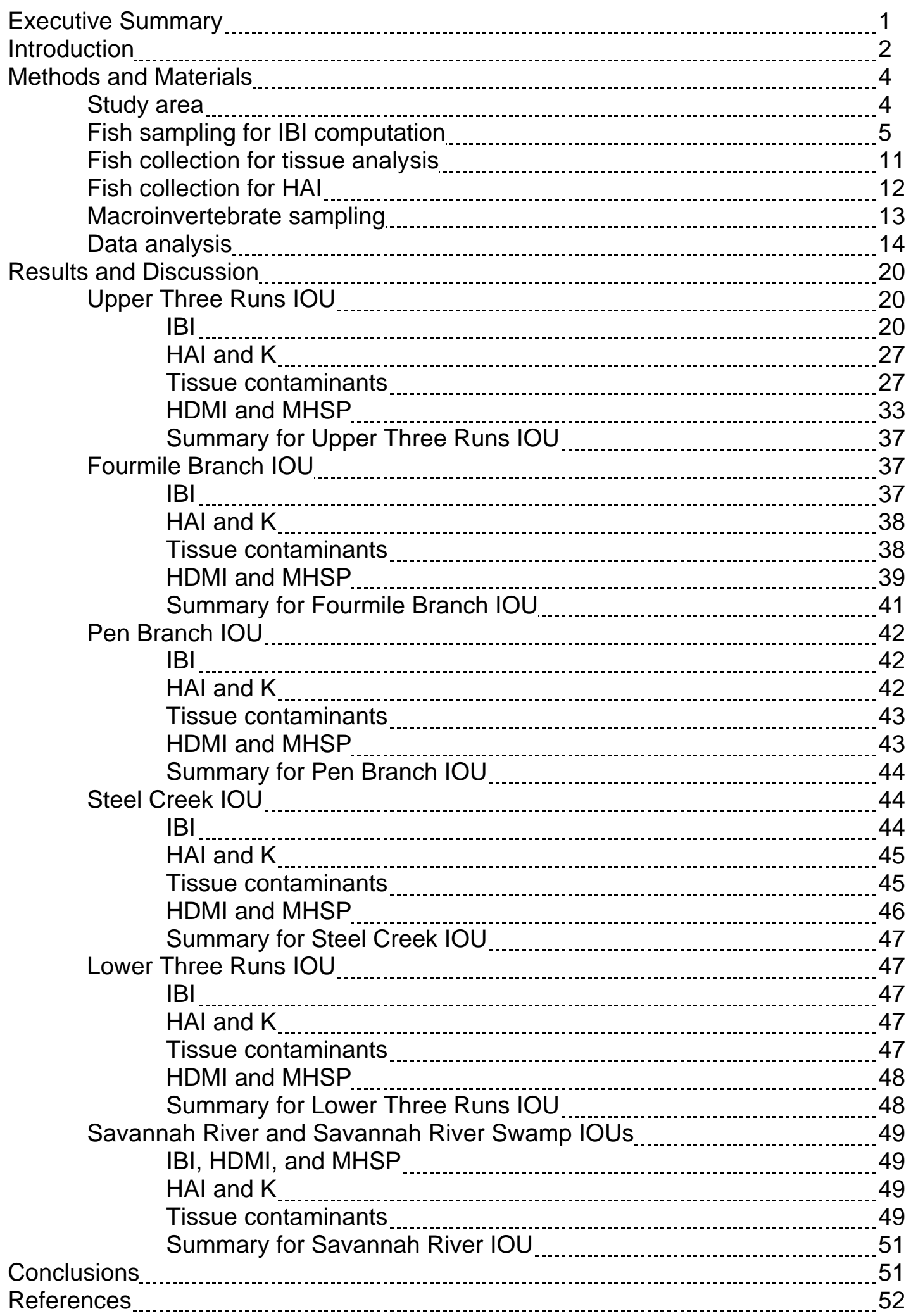


WSRC-TR-2003-00149

Rev. 0

March 27, 2003

\section{List of Figures}

Figure 1. Relationship between number of EPT taxa and stream size 19

Figure 2. Frequency distribution of IBI values from 29 relatively undisturbed stream sites in and near the SRS during 1990 to 1995

\section{List of Tables}

Table 1. Sample stations used for IOU evaluation 6

Table 2. Metrics and scoring criteria used in the modified Index of Biotic Integrity (IBI)

Table 3. Metrics and scoring criteria used in Hester-Dendy multimetric index (HDMI)

Table 4. Scores for EPT Taxa Richness and BI values for Sandhills/Coastal Plain Streams (from SCDHEC, 1998)

Table 5. IBI values from stream sites located in the Upper Three Runs (UTR), Fourmile Branch (FMB), Pen Branch (PB), Steel Creek (SC), and Lower Three Runs (LTR) Integrator Operable Units (IOUs)

Table 6. Means for habitat variables measured in streams in the Upper Three Runs (UTR), Fourmile Branch (FMB), Pen Branch (PB), Steel Creek (SC), and Lower Three Runs (LTR) Integrator Operable Units (IOUs) during 1996-2000

Table 7. Means for habitat variables measured in streams in the Upper Three

Runs (UTR), Fourmile Branch (FMB), Pen Branch (PB), Steel Creek (SC), and Lower Three Runs (LTR) Integrator Operable Units (IOUs) during 2003

Table 8. Health assessment index ( $\mathrm{HAl})$ and condition factors $(\mathrm{K})$ for redbreast sunfish collected from stream sites in the Integrator Operable Units (IOUs)

Table 9. Radioactive constituents (pc/g) commonly above detection limits in fish from the Savannah River Site Integrator Operable Units

Table 10. Nonradioactive constituents (ug/kg) commonly above detection limits in fish from the Savannah River Site Integrator Operable Units

Table 11. HDMI values from sites located in Upper Three Runs (UTR), Fourmile Branch (FMB), Pen Branch (PB), and Steel Creek (SC).

Table 12. MHSP water quality rating scores and habitat scores for streams in the Upper Three Runs (UTR), Fourmile Branch (FMB), Pen Branch (PB), Steel Creek (SC) and Lower Three Runs (LTR) Integrator Operable Units (IOUs)

Table 13. Condition factors $(K)$ and total lengths $(T L)$ of fish collected for tissue analysis. 
WSRC-TR-2003-00149

Rev. 0

March 27, 2003

\section{EXECUTIVE SUMMARY}

The Savannah River Site (SRS) has been divided into six Integrator Operable Units (IOUs) that correspond to the watersheds of the five major streams on the SRS (Upper Three Runs, Fourmile Branch, Pen Branch, Steel Creek, and Lower Three Runs) and the portions of the Savannah River and Savannah River Swamp associated with the SRS. The streams are the primary integrators within each IOU because they potentially receive, through surface or subsurface drainage, soluble contaminants from all waste sites within their watersheds. If these contaminants reach biologically significant levels, they would be expected to effect the numbers, types, and health of stream organisms. In this study, biological sampling was conducted within each IOU as a measure of the cumulative ecological effects of the waste sites within the IOUs. The use of information from biological sampling to assess environmental quality is often termed bioassessment. The IOU bioassessment program included 38 sites in SRS streams and nine sites in the Savannah River. Sampling was conducted in 1996 to 1998, 2000, and 2003.

Four bioassessment methods were used to evaluate ecological conditions in the IOU streams: the Index of Biotic Integrity, the Fish Health Assessment Index, measurement of fish tissue contaminant levels, and two benthic macroinvertebrate indices. The Index of Biotic Integrity (IBI) is an EPA supported method based on comparison of ecologically important and sensitive fish assemblage variables between potentially disturbed and reference (i.e., undisturbed) sites. It is designed to assess the ability of a stream to support a self-sustaining biological community and ecological processes typical of undisturbed, natural conditions. Since many types of contaminants can bioaccumulate, fish tissue contaminant data were used to determine the types of chemicals fish were exposed to and their relative magnitudes among IOUs. The Fish Health Assessment Index (HAI) is an EPA supported method for assessing the health and condition of individual fish based on dissection and internal examination. It helped to determine whether contaminant concentrations were high enough to adversely affect the health of individual fish. The benthic macroinvertebrate multimetric index (HDMI), used in 1997 to 2000, is a method for assessing stream health based on macroinvertebrate data collected with Hester-Dendy artificial substrates. In 2003 it was replaced with the Multiple Habitat Sampling protocol, a SCDHEC method for collecting and analyzing benthic macroinvertebrate data from natural substrate. These two macroinvertebrate based methods were used in conjunction with the fish based IBI to provide a more comprehensive assessment of ecological conditions. Lastly, habitat data were collected from each stream to assist in determining whether ecological integrity was compromised by physical factors (e.g., erosion) or chemical factors (e.g., discharge of toxic materials).

Fish from many SRS streams exhibited evidence of contamination as a result of current or former SRS operations. The most prevalent radiological contaminants were cesium-137 (highest in fish from Lower Three Runs followed by Steel Creek and Fourmile Branch), tritium (highest in fish from Fourmile Branch followed by Pen Branch, and the Savannah River swamp), and strontium (highest in fish from Fourmile Branch followed by Pen Branch). Radiological contaminants were also found in fish collected from the Savannah River near the mouths of contaminated SRS streams; however, contaminant levels were substantially lower than in fish from the streams themselves. Mercury levels were moderately elevated in fish from some streams, particularly Lower Three Runs, and in fish from the Savannah River. Despite the occurrence of contaminants, most SRS streams exhibited comparatively high biotic integrity (based on 
WSRC-TR-2003-00149

Rev. 0

March 27, 2003

IBI, HDMI, and MHSP scores) and minimal levels of pathology among individual fish (e.g., presence of tumors or extreme thinness), indicating that contaminant levels were generally insufficient to cause significant ecological degradation.

A few areas did exhibit ecological degradation, as indicated by low IBI, HDMI, or MHSP scores. Most were small tributaries or the smaller upper reaches of larger streams. These areas included Tims Branch, Crouch Branch, McQueen Branch, and the upper portions of Fourmile Branch, Steel Creek, and Meyers Branch. Degradation in upper Steel Creek was probably at least partly the result of habitat (isolation of this portion of the stream by L Lake plus erosion and siltation), and degradation in the upper portion of Tims Branch was probably at least partly related to naturally occurring low oxygen levels and high iron levels. Degradation in Crouch Branch, a small tributary of Upper Three Runs, may have been partly habitat related but was also related to the discharge of an NPDES effluent with elevated copper levels. Conditions in this stream have improved with improvements in effluent quality. Degradation in the upper portion of McQueen Branch appears to be habitat related, but the possible influence of NPDES discharges cannot be excluded. The cause of degradation in Fourmile Branch near Road 4 is uncertain but may be related to elevated metal concentrations as a result of past industrial operations. The upper portion of Meyers Branch was upstream from all waste sites and industrial areas, and low biotic integrity in this area was habitat related.

Repeated sampling of fish and macroinvertebrate assemblages at a number of sites during 1996 to 2003 suggested that no streams declined in ecological health over time and that several (i.e., Fourmile Branch and Crouch Branch) improved . Similarly, there was no evidence that fish tissue contaminants increased over time in any stream, and tritium levels decreased in Fourmile Branch fish.

\section{INTRODUCTION}

The Savannah River Site Integrator Operable Unit (IOU) program represents an effort to understand the cumulative impacts and potential risks of hazardous waste sites within each of the watersheds on the SRS. These watersheds are referred to as Integrator Operable Units because the streams within each watershed integrate the effects of all waste sites within the watershed. This integration results from the transport of soluble contaminants from any or all waste sites and discharges within the watershed to the stream by surface runoff or subsurface discharge. Organisms within the stream represent a further level of integration, since the types of organisms living in the stream and their condition is an integrated function of chemical and physical conditions in the stream.

The use of information about the organisms within a stream to assess environmental quality is often termed bioassessment. Bioassessment is increasingly favored by regulatory agencies because it explicitly evaluates effects on receptor organisms and reflects the cumulative effects of ecological disturbances (Plafkin et al. 1989). The Index of Biotic Integrity (IBI) is a bioassessment method that uses fish assemblage data to assess the biotic integrity of streams (Karr et al. 1986). Biotic integrity is the ability of a stream to support a self-sustaining biological community and ecological processes typical of undisturbed, natural conditions (Angermeier and Karr 1994). The IBI is referred to as a multimetric index since it is composed of a number of community, population, and organism level variables (or metrics) that are ecologically important and sensitive to environmental disturbances of various types. These variables 
WSRC-TR-2003-00149

Rev. 0

March 27, 2003

are measured at assessment sites, compared with the same variables in a range of similar but undisturbed benchmark streams, and the results summarized in a single number that reflects the extent to which the assessment site resembles the benchmarks. The IBI is supported by the USEPA and has been adapted for use throughout the United States and in a number of foreign countries (Plafkin et al. 1989, Klemm et al. 1993). It has been modified for use in SRS streams where it accurately discriminated undisturbed sites from sites affected by physical habitat alterations and chemical pollution (Paller et al. 1996).

The IBI was used in this study to evaluate the biotic integrity of streams in the five IOUs associated with SRS stream systems. It was supplemented with habitat data, with data on contaminant levels in fish tissues, and with two other bioassessment methods, the Fish Health Assessment Index (HAI, Adams et al. 1993), and a benthic macroinvertebrate index. The use of this supplementary data helped to assess biotic integrity more accurately and identify factors responsible for reduced biotic integrity. Identification of these factors was important because there are many types of disturbances on the SRS in addition to those that could result from SRS waste sites and industrial operations (which were of primary concern from the perspective of IOU evaluation). Habitat data assisted in determining whether ecological integrity was compromised by physical factors (e.g., erosion) or chemical factors (e.g., discharge of toxic materials). Since many types of contaminants can bioaccumulate, fish contaminant data assisted in determining what types of chemical contaminants fish were exposed to and their relative magnitudes among IOUs and among sample areas within IOUs. The $\mathrm{HAl}$ is an EPA supported method for assessing the health and condition of individual fish (Klemm et al. 1993). It assisted in determining whether contaminant concentrations were high enough to adversely affect the health of individual fish.

Biological surveys can involve various taxonomic assemblages including fish, benthic macroinvertebrates, and periphyton (Barbour et al. 1997). Although bioassessments are often based on only a single assemblage for reasons of time, economics, and available expertise, a more complete and accurate assessment can be produced by the use of more than one taxonomic assemblage (Barbour et al. 1997, Paller 2001). This is particularly important because different taxonomic groups may respond differently to the same stressors (Mount et al. 1984, Yoder and Mount 1995). Benthic macroinvertebrate data have been collected from SRS streams on several occasions, although not as part of the IOU sampling program. A multimetric index analogous to the IBI was developed for analyzing this macroinvertebrate data (Paller and Specht 1997); this index was termed the Hester-Dendy multimetric index (HDMI). More recently, SCDHEC (South Carolina Department of Health and Environmental Control) developed a bioassessment protocol for macroinvertebrate data collected from natural substrates referred to as the Multiple Habitat Sampling Protocol (MHSP, 1998). To provide a more comprehensive analysis, these macroinvertebrate based methods were combined with the IBI to assess ecological conditions in the SRS IOUs.

Bioassessment to determine the cumulative effects of SRS waste sites on the ecological health of SRS streams was initiated in 1996-1998. Additional sampling was conducted in 2000 and 2003 to assess possible changes in ecological health that may have occurred over time and to obtain information from several sites that were previously unsampled. Data collected in 1996-1998 and in 2000 have been published in previous reports (Paller and Dyer 1999, Paller and Dyer 2003). The current report 
WSRC-TR-2003-00149

Rev. 0

March 27, 2003

includes the findings of these earlier studies as well as the results of sampling conducted during 2003. Objectives of this study were to:

1. Assess the biotic integrity of streams in the Upper Three Runs, Fourmile Branch, Pen Branch, Steel Creek, and Lower Three Runs IOUs.

2. Use the HAI to determine if fish health has been impaired in the IOUs.

3. Determine contaminant levels in fish from all of the IOUs.

4. Identify factors that may be impairing biotic integrity in the IOUs.

Study area

\section{METHODS AND MATERIALS}

The Savannah River Site (SRS) has been divided into six IOUs. Five of these correspond to the drainage basins of the five major streams on the SRS: Upper Three Runs, Fourmile Branch, Pen Branch, Steel Creek, and Lower Three Runs. The remaining IOU is the portion of the Savannah River and Savannah River Swamp associated with the SRS (i.e., the portion extending from the upstream boundary of the SRS down to Lower Three Runs).

The Upper Three Runs IOU encompasses a large area that includes portions of Aiken and Barnwell counties located outside of the SRS. Approximately $250 \mathrm{~km}^{2}$ of the Upper Three Runs watershed is within the SRS. Tributaries of Upper Three Runs located within the SRS include Tinker Creek, Tims Branch, Crouch Branch, and McQueen Branch. Mill Creek and Reedy Branch are also located within the Upper Three Runs IOU, but these streams discharge into Upper Three Run's main tributary, Tinker Creek, rather than directly into Upper Three Runs. There are a number of SRS operational facilities and waste areas within the Upper Three Runs IOU (WSRC 1998a); however, much of Upper Three Runs is located upstream from SRS industrial areas. Similarly, Tinker Creek, Mill Creek, and Reedy Branch are in portions of the SRS that are largely undisturbed. Several chemical constituents of potential concern from human health or ecological perspectives have been found in water and/or sediments within portions of Upper Three Runs (WSRC 1998a).

Fourmile Branch is a $24 \mathrm{~km}$ long stream that lies entirely within the SRS. The 57 $\mathrm{km}^{2}$ watershed of Fourmile Branch includes a number of SRS facilities, waste sites, and discharges, WSRC 1998b). Except for the extreme headwaters, most of Fourmile Branch is potentially influenced by SRS discharges and industrial operations. A number of radioactive and nonradioactive constituents of potential concern have been detected in environmental media collected from Fourmile Branch (WSRC 1998b). Fourmile Branch received large volumes of heated cooling water from $C$ Reactor, which resulted in extensive habitat destruction and elimination of most biota. Recovery and recolonization began in 1985 with the shutdown of C-Reactor, and secondary succession is now well underway in the Fourmile Branch stream channel and riparian zone.

The Pen Branch IOU includes Pen Branch and Indian Grave Branch, both of which are entirely within the SRS. The headwaters of Pen Branch are largely unperturbed. However, Pen Branch has been affected by SRS reactor operations and other industrial activities below its confluence with Indian Grave Branch. Pen Branch terminates in the Savannah River swamp, and unlike most of the other streams in this study, does not have a clearly defined channel through the swamp to the Savannah River. Except for the extreme headwaters, nearly the entirety of Indian Grave Branch 
WSRC-TR-2003-00149

Rev. 0

March 27, 2003

has been affected by SRS reactor operations. During K Reactor operation, heated cooling water entered Indian Grave Branch and flowed into Pen Branch causing the same type of habitat destruction described for Fourmile Branch. Recovery began in 1988 with the cessation of K-reactor operations.

The Steel Creek IOU includes Steel Creek and Meyers Branch. Steel Creek originates near P-Reactor Area and flows approximately $3 \mathrm{~km}$ before entering the headwaters of L Lake, a $7 \mathrm{~km}$ long, 400 ha cooling reservoir constructed in 1985. Water discharged from the $L$ Lake dam enters the middle portion of Steel Creek and flows approximately $5 \mathrm{~km}$ to the Savannah River swamp and about $2 \mathrm{~km}$ more through the swamp to the Savannah River. The entirety of Steel Creek is potentially affected by SRS discharges, waste sites, and/or industrial operations. The middle and lower portion of Steel Creek suffered extensive habitat degradation from high temperature reactor cooling water during 1954 to 1968. Industrial facilities and waste sites in the Steel Creek IOU, as well as potential contaminants of concern, are summarized in WSRC(1998c). Meyers Branch, the primary tributary of Steel Creek, is largely unaffected by SRS operations.

Lower Three Runs drains the southeastern portion of the SRS. Its upper reaches were dammed to form Par Pond, a 1012 ha reservoir formerly used for reactor cooling. Water discharged from the Par Pond dam flows another $30 \mathrm{~km}$ through Lower Three Runs before entering the Savannah River. Throughout much of this distance, SRS property consists of only a narrow strip of land bordering the stream banks. Industrial facilities and waste units occurring in the upper reaches of the Lower Three Runs IOU are summarized in WSRC (1998d).

The Savannah River IOU encompasses the portion of the Savannah River and the associated floodplain swamp that extends from the upstream boundary of the plant down to Lower Three Runs. The Savannah River swamp receives discharge from Fourmile Branch, Pen Branch, and Steel Creek and is characterized by complex patterns of water flow and occasional complete inundation by the Savannah River. It can, therefore, be potentially affected by contaminants from several SRS streams, as well as contaminants originating upstream of the SRS.

\section{Fish sampling for IBI computation}

Fish assemblage data for computation of the IBI have been collected at 27 sites during 1996-2003 (Table 1) including:

- $\quad$ six in the Steel Creek IOU (four in Steel Creek, two in Meyers Branch),

- ten in the Upper Three Runs IOU (three in Upper Three Runs, one in Mill Creek, one in Tims Branch, two in Crouch Branch, two in McQueen Branch, and one in Tinker Creek),

- four in the Fourmile Branch IOU (all in Fourmile Branch),

- five in the Pen Branch IOU (five in Pen Branch and one in Indian Grave Branch),

- $\quad$ and two in the Lower Three Runs IOU (Table 1).

Seven of these sites (one in Mill Creek, one in Meyers Branch, two in Pen Branch, two in Upper Three Runs, and one in Tinker Creek) were located upstream from SRS industrial areas or waste sites and were representative of conditions unaffected by SRS 
Table 1. Sample stations used for IOU evaluation. Also indicated are the station type (reference [R] or possibly impacted by SRS waste sites $[\mathrm{PI}])$, and the type of data collected at each sample station: Index of Biotic Integrity (IBI), habitat $(\mathrm{H})$, tissue contaminant levels in whole fish (T), tissue contaminant levels in fish fillets (TF), fish Health Assessment Index (HAI), fish condition factors (K), Hester-Dendy macroinvertebrate index (HDMI) or Multiple Habitat Sampling Protocol (MHSP).

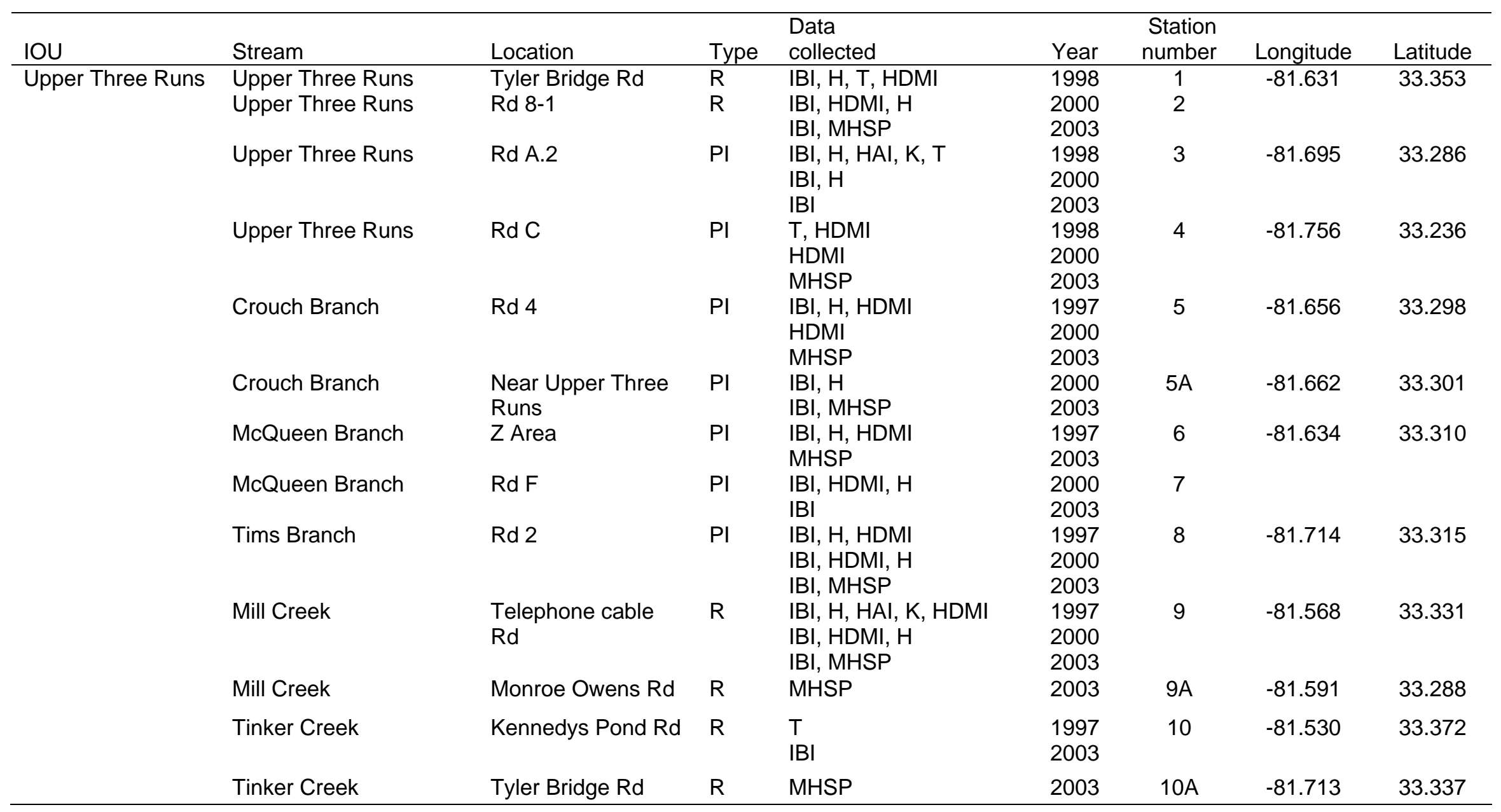


WSRC-TR-2003-00149

Rev. 0

March 27, 2003

\begin{tabular}{|c|c|c|c|c|c|c|c|c|}
\hline & & & & Data & & Station & & \\
\hline IOU & Stream & Location & Type & Collected & Year & Number & Longitude & Latitude \\
\hline \multirow[t]{17}{*}{ Fourmile Branch } & \multirow[t]{2}{*}{ Fourmile Branch } & \multirow[t]{2}{*}{$\mathrm{Rd} \mathrm{F}$} & \multirow[t]{2}{*}{$\mathrm{R}$} & HDMI & 1997 & \multirow[t]{2}{*}{11} & \multirow[t]{2}{*}{-81.612} & \multirow[t]{2}{*}{33.281} \\
\hline & & & & HDMI & 2000 & & & \\
\hline & \multirow[t]{2}{*}{ Fourmile Branch } & \multirow[t]{2}{*}{$\mathrm{Rd} 4$} & \multirow[t]{2}{*}{ PI } & IBI, H & 1997 & \multirow[t]{2}{*}{12} & \multirow[t]{2}{*}{-81.653} & \multirow[t]{2}{*}{33.275} \\
\hline & & & & MHSP & 2003 & & & \\
\hline & \multirow[t]{3}{*}{ Fourmile Branch } & \multirow[t]{3}{*}{$\mathrm{Rd} C$} & \multirow[t]{3}{*}{$\mathrm{PI}$} & $\mathrm{IBI}, \mathrm{H}$ & 1997 & \multirow[t]{3}{*}{13} & \multirow[t]{3}{*}{-81.669} & \multirow[t]{3}{*}{33.273} \\
\hline & & & & IBI, HDMI, H & 2000 & & & \\
\hline & & & & IBI & 2003 & & & \\
\hline & \multirow[t]{3}{*}{ Fourmile Branch } & \multirow[t]{3}{*}{ Rd A-6 } & \multirow[t]{3}{*}{$\mathrm{Pl}$} & IBI, H & 1997 & \multirow[t]{3}{*}{14} & \multirow[t]{3}{*}{-81.696} & \multirow[t]{3}{*}{33.248} \\
\hline & & & & IBI, HDMI, H & 2000 & & & \\
\hline & & & & IBI & 2003 & & & \\
\hline & \multirow[t]{2}{*}{ Fourmile Branch } & \multirow[t]{2}{*}{$\mathrm{Rd} A-7$} & \multirow[t]{2}{*}{$\mathrm{Pl}$} & HDMI & 1997 & 15 & -81.696 & 33.244 \\
\hline & & & & MHSP & 2003 & & & \\
\hline & Fourmile Branch & $\mathrm{Rd} A$ & $\mathrm{Pl}$ & IBI, H, HAI, K, T & 1997 & 16 & -81.713 & 33.214 \\
\hline & & & & IBI, HDMI, H & 2000 & & & \\
\hline & & & & TF & 2001 & & & \\
\hline & & & & IBI, MHSP & 2003 & & & \\
\hline & Fourmile Branch & Rd A13.2 & $\mathrm{Pl}$ & $\mathrm{T}$ & 2001 & 17 & & \\
\hline Pen Branch & Pen Branch & $\mathrm{Rd} \mathrm{C}$ & $\mathrm{R}$ & IBI, H, HDMI & 1997 & 18 & -81.624 & 33.233 \\
\hline & & & & IBI, HDMI, H & 2000 & & & \\
\hline & & & & IBI, MHSP & 2003 & & & \\
\hline & Pen Branch & $\mathrm{Rd} B$ & $\mathrm{R}$ & IBI, H, T, HDMI & 1997 & 19 & -81.647 & 33.204 \\
\hline & & & & IBI, HDMI, H & 2000 & & & \\
\hline & & & & IBI, MHSP & 2003 & & & \\
\hline & Pen Branch & $\mathrm{Rd} A$ & $\mathrm{Pl}$ & IBI, H, HAI, K, T, & 1997 & 20 & -81.667 & 33.183 \\
\hline & & & & HDMI & 2000 & & & \\
\hline & & & & MHSP & 2003 & & & \\
\hline & Pen Branch & Rd A13.2 & $\mathrm{Pl}$ & $|B|, \mathrm{H}$ & 2000 & 21 & -81.686 & 33.160 \\
\hline & & & & $\mathrm{T}$ & 2001 & & & \\
\hline & & & & IBI & 2003 & & & \\
\hline & Indian Grave Branch & K Cooling Tower & $\mathrm{Pl}$ & IBI, H, HDMI & 1997 & 22 & -81.675 & 33.203 \\
\hline & & & & IBI, HDMI, H & 2000 & & & \\
\hline & & & & IBI, MHSP & 2003 & & & \\
\hline
\end{tabular}




\begin{tabular}{|c|c|c|c|c|c|c|c|c|}
\hline IOU & Stream & Location & Type & $\begin{array}{l}\text { Data } \\
\text { Collected }\end{array}$ & Year & $\begin{array}{l}\text { Station } \\
\text { Number }\end{array}$ & Longitude & Latitude \\
\hline \multirow[t]{16}{*}{ Steel Creek } & Steel Creek & $\mathrm{Rd} \mathrm{C}$ & $\mathrm{Pl}$ & $\mathrm{IBI}, \mathrm{H}, \mathrm{HAI}, \mathrm{K}, \mathrm{T}$ & 1996 & 23 & -81.606 & 33.212 \\
\hline & & & & IBI, H, HDMI & 1997 & & & \\
\hline & & & & IBI, HDMI, H & 2000 & & & \\
\hline & & & & IBI, MHSP & 2003 & & & \\
\hline & Steel Creek & P Area & $\mathrm{Pl}$ & $\mathrm{IBI}, \mathrm{H}$ & 1996 & 24 & -81.598 & 33.222 \\
\hline & Steel Creek & L Lake dam & $\mathrm{Pl}$ & IBI, H, HAI, K & 1996 & 25 & -81.632 & 33.159 \\
\hline & Steel Creek & $\mathrm{Rd} A$ & $\mathrm{Pl}$ & IBI, H, T, HDMI & 1996 & 26 & -81.629 & 33.146 \\
\hline & & & & IBI, $\mathrm{H}$ & 2000 & & & \\
\hline & & & & IBI & 2003 & & & \\
\hline & Steel Creek & Swamp & $\mathrm{Pl}$ & $\mathrm{T}$ & 1997 & 27 & -81.631 & 33.114 \\
\hline & Meyers Branch & Old Dunbarton Rd & $\mathrm{R}$ & IBI, H, HDMI & 1997 & 28 & -81.582 & 33.185 \\
\hline & & & & IBI, H, HAI, K, T & 1996 & & & \\
\hline & & & & IBI, HDMI, H & 2000 & & & \\
\hline & & & & IBI, MHSP & 2003 & & & \\
\hline & Meyers Branch & $\mathrm{Rd} 9$ & $\mathrm{R}$ & IBI, H & 1997 & 29 & -81.601 & 33.167 \\
\hline & Meyers Branch & Rd B-6.2 & $\mathrm{R}$ & MHSP & 2003 & $29 A$ & -81.566 & 33.207 \\
\hline \multirow[t]{7}{*}{ Lower Three Runs } & Lower Three Runs & $\mathrm{Rd} B$ & $\mathrm{Pl}$ & $\mathrm{T}$ & 1997 & 30 & & \\
\hline & Lower Three Runs & Donora Station & $\mathrm{Pl}$ & IBI, H, HAI, K & 1997 & 31 & -81.509 & 33.222 \\
\hline & & & & HDMI & 2001 & & & \\
\hline & & & & IBI, MHSP & 2003 & & & \\
\hline & Lower Three Runs & Patterson Mill & $\mathrm{Pl}$ & IBI, MHSP & 2003 & $31 \mathrm{~A}$ & -81.481 & 33.176 \\
\hline & Lower Three Runs & Stinson Bridge & $\mathrm{Pl}$ & $\mathrm{T}, \mathrm{HDMI}$ & 2001 & 32 & -81.455 & 33.135 \\
\hline & Lower Three Runs & HW 125 & $\mathrm{PI}$ & TF & 2001 & 33 & -81.477 & 33.073 \\
\hline \multirow[t]{8}{*}{ Savannah River } & Savannah River & N. Augusta Rapids & $\mathrm{R}$ & $\mathrm{T}$ & 1999 & 34 & -81.991 & 33.503 \\
\hline & & & & $\mathrm{T}, \mathrm{TF}$ & 2001 & & & \\
\hline & Savannah River & Lock \& Dam & $\mathrm{Pl}$ & $\mathrm{T}$ & 1999 & 35 & -81.947 & 33.371 \\
\hline & Savannah River & Upper Three Runs & $\mathrm{Pl}$ & $\mathrm{T}$ & 1999 & 36 & -81.773 & 33.221 \\
\hline & Savannah River & near TNX & $\mathrm{PI}$ & $\mathrm{T}$ & 2001 & 37 & -81.766 & 33.210 \\
\hline & Savannah River & Fourmile Branch & $\mathrm{Pl}$ & $\mathrm{T}$ & 1999 & 38 & -81.752 & 33.147 \\
\hline & Savannah River & Steel Creek & $\mathrm{Pl}$ & $\mathrm{T}$ & 1999 & 39 & -81.618 & 33.096 \\
\hline & Savannah River & Lower Three Runs & $\mathrm{Pl}$ & $\mathrm{T}$ & 1999 & 40 & -81.514 & 33.029 \\
\hline
\end{tabular}


WSRC-TR-2003-00149

Rev. 0

March 27, 2003

Table 1. continued

\begin{tabular}{|c|c|c|c|c|c|c|c|c|}
\hline $\mathrm{IOU}$ & Stream & Location & Type & $\begin{array}{l}\text { Data } \\
\text { Collected }\end{array}$ & Year & $\begin{array}{l}\text { Station } \\
\text { Number }\end{array}$ & Longitude & Latitude \\
\hline & Savannah River oxbow & Coleman Pond & $\mathrm{PI}$ & $\mathrm{T}$ & 2001 & 41 & & \\
\hline
\end{tabular}


WSRC-TR-2003-00149

Rev. 0

March 27, 2003

operations. Fish assemblages in these locations (except for two in Upper Three Runs as described later) exhibited high biotic integrity and compared favorably with fish assemblages in relatively unimpacted offsite streams in terms of species richness, abundance, and other commonly used measures of biotic integrity (Paller 1992). The other sites were located in areas potentially affected by past or present SRS operations.

Thirteen of the IBI sites were sampled at least three times, usually in the summer and/or fall of 1997, 2000, and 2003. Most of the remaining sites were sampled twice. Some sites could not be sampled more than once or twice because they became inaccessible as a result of construction activities near access points or changes in water level caused by beavers. A number of sample sites identified in 1997 eventually became impounded by beavers and were no longer suitable for computation of the IBI, which was developed for fish assemblages residing in lotic habitats. Table 1 provides detailed information concerning sample dates and the types of data collected from each sample site.

Three $50 \mathrm{~m}$ stream segments were electrofished at each sample site. All sites except for those in Upper Three Runs and Lower Three Runs at Patterson Mill were sampled with a Coffelt backpack electrofisher powered by a generator, a Smith-Root backpack electrofisher powered by a battery, and/or a Smith-Root backpack electrofisher powered by a generator. A single pass was made through each $50 \mathrm{~m}$ segment at each site (while moving upstream) except during 2003, when two passes were made. All microhabitats were sampled in an effort to obtain as many species and individuals as possible. Fish were collected with dip nets after they had been stunned by DC current. One backpack electrofisher and a two or three person crew were used at relatively narrow sites. Two back pack electrofishers and two crews, with a crew covering each bank as both moved upstream simultaneously, were usually used at wider sites (in excess of $5 \mathrm{~m}$ ). A $4.25 \mathrm{~m}$ boat with a boat mounted generator and Smith-Root electrofisher was used to sample Upper Three Runs and Lower Three Runs at Patterson Mill, the widest (approximately 14-17m) and deepest (over $1.0 \mathrm{~m}$ ) sites. Each bank was sampled separately in Upper Three Runs and Lower Three Runs at Patterson Mill. All fish were identified to species and released.

Fish assemblage data were not collected from the Savannah River IOU (Table 1) because an index of biotic integrity has not been developed for river or swamp habitats on the SRS. Evaluation of river sample sites was based only on analysis of tissue samples.

Habitat data were collected from each fish assemblage sample site (i.e., each sample site used for IBI computation) to assist in the interpretation of the fish assemblage data. These data were collected from transects running across the stream perpendicular to the direction of water flow. Except at the sample sites in Upper Three Runs and Lower Three Runs at Patterson Mill, there were three transects evenly spaced within each $50 \mathrm{~m}$ section for a total of nine habitat transects per site. Because of the difficulty in obtaining habitat data from Upper Three Runs and Lower Three Runs at Patterson Mill, which were comparatively deep and wide, there were only two evenly spaced habitat transects per $50 \mathrm{~m}$ section in these streams. Excluding the 2003 samples, the following habitat data were collected at each transect:

- Stream width (distance from waters edge to waters edge).

- Depth of the stream (nearest $0.01 \mathrm{~m}$ ) at a minimum of approximately $20 \%, 40 \%$, $60 \%$, and $80 \%$ of the distance from the left bank to the right bank. 
WSRC-TR-2003-00149

Rev. 0

March 27, 2003

- Current velocity $(\mathrm{cm} / \mathrm{s})$ at each point where depth was measured. Where depth equaled or exceeded $0.6 \mathrm{~m}$, two current velocity measurements were taken, one at 0.2 times the depth and one at 0.8 times the depth. Where the depth was less than $0.6 \mathrm{~m}$, only one measurement was taken at 0.6 times the distance from the surface.

- Predominant substrate types (e.g., mud, sand, gravel, rocks) in the vicinity of the transect (i.e., $3 \mathrm{~m}$ upstream from the transect and $3 \mathrm{~m}$ downstream from the transect). Visual estimate.

- Bottom area (nearest 5\%) covered by debris (detritus and leaves). Visual estimate.

- Number of logs (i.e., recumbent wood in excess of $10 \mathrm{~cm}$ in diameter) in the vicinity of the transect.

- Number of stumps in the vicinity of the transect.

- Number of cypress knees in the vicinity of the transect.

- Bottom area (nearest 5\%) covered by fibrous root systems. Visual estimate.

- Bottom area (nearest 5\%) covered by brush piles. Visual estimate.

- Aquatic macrophyte cover (nearest 5\%) and the predominant types (submerged, emergent, floating) in the vicinity of the transect. Visual estimate.

- Amount of stream surface (nearest 5\%) overhung by low growing riparian vegetation (e.g. shrubs, grasses, and small trees) in the vicinity of the transect. Visual estimate.

- Canopy cover (nearest 5\%) and the predominant canopy types (cypress/tupelo forest, hardwood forest, pine forest) in the vicinity of the transect. Visual estimate.

- Bank erosion on a scale of zero (none) to severe (three). Visual Estimate.

A simplified habitat sampling protocol was employed during 2003. It included stream width, maximum channel depth, current velocity, predominant substrate type, percent bottom area covered by underwater debris of all types, percent bottom area covered by underwater vegetation, and overhead canopy cover. The latter three variables were visually estimated to the nearest 5 percent. In addition, a YSI 556 water quality meter was used to measure conductivity, $\mathrm{pH}$, dissolved oxygen, and temperature at each fish sample site during 2003.

Fish collection for tissue analysis six IOUs:

Fish samples for tissue analysis were collected from 25 locations representing all

- three sample sites in Upper Three Runs and one in Tinker Creek,

- two in Fourmile Branch,

- three in Pen Branch,

- three in Steel Creek and one in Meyers Branch,

- three in Lower Three Runs, and

- $\quad$ nine in the Savannah River (Table 1).

The two upstream most sample sites on Upper Three Runs, the sample site on Tinker Creek, the two upstream most sample sites on Pen Branch, the sample site on Meyers Branch, and the sample site in the Savannah River near the North Augusta rapids were located upstream from SRS industrial areas or waste sites and represented areas largely uncontaminated by direct discharge from SRS waste sites or industrial facilities. These sample areas were considered reference areas for fish tissue analysis despite the possibility of some movement of contaminated fish into them from locations directly affected by SRS operations. Fish tracking studies, including ongoing radio telemetry studies on SRS largemouth bass, indicate that most species commonly found in warmwater streams, such as those on the SRS, typically make relatively limited 
WSRC-TR-2003-00149

Rev. 0

March 27, 2003

movements and are unlikely to have moved into the reference sites from contaminated areas (Berra and Gunning 1972, Gatz and Adams 1994, Jones 2001).

Three composite samples, each consisting of at least three fish and totaling at least $400 \mathrm{~g}$ (the minimum acceptable for laboratory analysis) were collected from most samples sites (exceptions described later). An effort was made to represent three different trophic groups among the three composite samples including a predatory species, a benthic species, and a midwater insectivorous species. Although each composite sample consisted of only one species, the species comprising each trophic group differed among sample areas because the sample areas supported different species. However, the midwater insectivorous fish was generally the redbreast sunfish. Replication within each trophic group and sample area was usually impossible because of the scarcity of fish in relation to the tissue mass required for analysis. Approximately $10 \%$ of the samples were split (after the sample was homogenized) as a check on analytical accuracy. Analytical values for split samples were generally very similar.

Each composite fish sample was placed on ice and conveyed to an analytical laboratory where it was analyzed for gamma PHA, gross alpha, nonvolatile beta, plutonium series, RCRA (Resource Conservation and Recovery Act) metals, strontium$80 / 90$, TCL VOA (target compound list volatile organic analytes), tritium, and uranium. These analytes were selected on the basis of their known or suspected occurrence on the SRS as a result of past and/or current SRS operations and releases. Specific analytes within each of these categories will be listed later. Analytical methods are described in EPD (1997 and 1998).

\section{Fish collection for HAl}

For comparability of results, only one species, redbreast sunfish, was collected for determination of the HAI. This species was selected because it was fairly abundant at most sample locations making it possible to collect sufficient individuals for statistically meaningful comparisons. Because they are members of the Centrarchidae (sunfish) family, one of the most abundant families of fish on the Savannah River Site (Paller 1994), redbreast sunfish are probably representative of many other fishes on the SRS in terms of sensitivity to toxicants.

Redbreast sunfish for HAl determination were collected from nine locations in all six IOUs (Table 1):

- Steel Creek upstream from L Lake, Steel Creek downstream from L Lake,

- Lower Three Runs near Donora Station,

- Pen Branch near Road A

- Fourmile Branch near Road A,

- Savannah River Swamp,

- Upper Three Runs near Road A-2, Upper Three Runs near Tyler Bridge, and

- Meyers Branch.

Approximately 10 individuals of moderate to large size were collected by electrofishing from each sample site and returned to the laboratory where they were sacrificed, weighed, measured (total length), and examined using the methods described in Klemm et al. (1993). Sixteen variables were recorded for each fish including:

- blood parameters (hematocrit, leukocrit, plasma protein);

- length and weight,

- appearance of the eyes, gills, pseudobranchs, spleen, kidneys, liver, hindgut; and 
WSRC-TR-2003-00149

Rev. 0

March 27, 2003

- damage to the skin, fins, and thymus.

\section{Macroinvertebrate sampling}

Macroinvertebrate samples have been taken at a number of locations within SRS streams including:

- four in the Steel Creek IOU (two in Steel Creek and two in Meyers Branch),

- eleven in the Upper Three Runs IOU (three in Upper Three Runs, two in Mill Creek, one in Tims Branch, two in Crouch Branch, two in McQueen Branch, and one in Tinker Creek),

- six in the Fourmile Branch IOU (all in Fourmile Branch),

- four in the Pen Branch IOU (three in Pen Branch and one in Indian Grave Branch)

- $\quad$ and three in the Lower Three Runs IOU (both in Lower Three Runs) (Table 1). Macroinvertebrate samples from 1997-1998 and 2000 were collected during the SRS NPDES sampling program (Specht and Paller 1998). Samples from 2003 were collected as part of the IOU sampling program. Table 1 provides detailed information concerning macroinvertebrate sampling times and locations.

Macroinvertebrates samples from 1997-1998 and 2000 were collected with Hester-Dendy multiplate samplers. Five samplers were deployed at each site during the fall and winter (prior to the emergence of most species and when larvae were easiest to identify because of their relatively large size). Each sampler consisted of fourteen 7.6 $\mathrm{cm}$ plates separated by approximately $0.3-1.0 \mathrm{~cm}$ (total surface area of $0.179 \mathrm{~m}^{2}$ ). Samplers were hung from a line suspended across the stream so that none were in direct contact with the substrate. The samplers were retrieved after 28 days. Organisms were removed from the samplers and preserved in $70 \%$ ethanol. Macroinvertebrates were taken to the laboratory for microscopic identification using appropriate taxonomic references. Most specimens were identified to the genus level.

In 2003, stream macroinvertebrates were sampled following SCDHEC's TimedQualitative Multiple Habitat Sampling Protocol (MHSP) (SCDHEC, 1998), which involves the collection of macroinvertebrates from natural substrates rather than Hester-Dendy samplers. This protocol uses a timed, qualitative, multiple habitat sampling approach consisting of a three man-hour sampling effort at each sampling location. All available natural habitats were sampled with a D-frame dip net, kick net, hand sieve, white plastic pan and fine mesh sampler with the objective of collecting as many different macroinvertebrate taxa as possible during the allotted time. Macroinvertebrates were placed in jars or vials containing $85 \%$ ethanol; labeled with the station number, collector, and collection date; and returned to the laboratory for microscopic identification. The MHSP protocol is designed to ensure that all the habitats at a site are thoroughly sampled to obtain a good representation of the macroinvertebrate community. Details of the sampling protocol are provided in SCDEC, 1998.

Habitat quality was assessed in conjuction with the MHSP using a methodology developed by SCDHEC (1998). Variables included epifaunal substrate, pool substrate, pool variability, sediment deposition, channel flow status, channel alteration, channel sinuosity, bank stability, vegetative protection, and riparian vegetation. Physicochemical parameters (dissolved oxygen, $\mathrm{pH}$, temperature, and specific conductance) were measured in conjunction with the habitat assessment. 
WSRC-TR-2003-00149

Rev. 0

March 27, 2003

Data Analysis

The IBI used in the IOU studies was a variation of the Index of Biotic Integrity (IBI) adjusted for the composition of the ichthyofauna of the upper South Carolina coastal plain. It included 10 metrics, each scored one, three, or five which summed to a maximum total index value of 50 (Paller et al. 1996) (Table 2). It also adjusted for differences in sample area (i.e., species/area effect), stream size, and sampling effort making it possible to directly compare IBI values from streams and sample areas of different size (Paller et al. 1996) as well as stream reaches sampled with different numbers of passes. The IBI was calculated for each $50 \mathrm{~m}$ segment at each location.

The statistical significance of differences between IBIs at sites potentially influenced by SRS waste sites (i.e., sites located downstream from SRS waste sites) and reference sites was assessed with the Kruskal-Wallis test $(P \leq 0.05)$, followed by a Dunn's test for comparisons between the pooled reference sites and individual potentially impacted sites $(\mathrm{P} \leq 0.05)$. Three sets of tests were conducted, one for the data collected in 1997/1998, a second for the data collected during 2000, and a third for the data collected during 2003. The reference sample sites were located upstream from SRS waste sites. Reference sites used to test the 1997/1998 and 2000 data included Pen Branch Rd B, Pen Branch Rd C, Meyers Branch, and Mill Creek. An additional reference site, Tinker Creek at Kennedy Pond was added to the 2003 test. All exhibited IBI values (averages of 42.7-50.0) well within the range expected in undisturbed streams. Upper Three Runs sites near Tyler Bridge and Road 8-1, while upstream of all known SRS waste sites, exhibited comparatively low IBIs for possible reasons that will be discussed later. Because they were not representative of most undisturbed streams (Paller et al. 1996), IBI values from Upper Three Runs near Tyler Bridge and Road 8-1 were not grouped with the other reference sites for statistical comparisons.

In addition to the preceding statistical analyses, the average IBI at each sample site $(n=3)$ was compared to IBI values at 29 largely undisturbed locations sampled during previous sampling programs. This analysis provided an additional measure of the range of variation in IBI values from relatively undisturbed streams. The 29 sites were sampled during 1990 - 1995 using methods similar to those used in this study (Paller 1992). They were located in Meyers Branch, Mill Creek, Reedy Branch, Tinker Creek, and portions of Hollow Creek, Upper Three Runs, Buck Creek, Gant's Mill Creek, Bodiford Mill Creek, Pen Branch, and Miller Creek. None of the 29 sites suffered from obvious anthropogenic disturbances or point discharges, although some may have been affected by land use practices (e.g., agriculture) in their watersheds.

The multimetric index for Hester-Dendy samples (HDMI), as originally developed (Paller and Specht 1997), included eight metrics, each scored one, three, or five for a maximum total index value of 40 (Table 3). However, one metric (percentage Tanytarsini) was not used when analyzing the 1997/1998 data because this taxonomic group was rare at all sample sites during those years. This reduced the maximum index value to 35 for the 1997/1998 data. As with the IBI data, Kruskal-Wallis and Dunn's tests were used to assess the significance of differences in the HDMI between potentially disturbed and reference sites (i.e., Pen Branch Rd C, Pen Branch Rd B, Meyers Branch, Mill Creek, Upper Three Runs Tyler Bridge. The 1997/1998 data and 2000 data were tested separately.

Data collected with the MHSP was analyzed to produce a bioclassification rating based on two metrics, the number of EPT (Ephemeroptera, Plecoptera, Trichoptera) 
WSRC-TR-2003-00149

Rev. 0

March 27, 2003

Table 2. Metrics and scoring criteria used in the modified Index of Biotic Integrity (IBI). Individual metrics are assigned scores of one, three, or five.

\begin{tabular}{|c|c|c|c|}
\hline \multirow[b]{2}{*}{ Metrics } & \multicolumn{3}{|c|}{ Scoring criteria } \\
\hline & 1 & 3 & 5 \\
\hline \multicolumn{4}{|l|}{ Species richness } \\
\hline $\begin{array}{l}\text { Percentage of expected number of } \\
\text { total species (TSP) }\end{array}$ & $<70$ & $70-90$ & $>90$ \\
\hline $\begin{array}{l}\text { Percentage of expected number of } \\
\text { native minnow species }(\mathrm{CSP})^{\mathrm{a}}\end{array}$ & $<55$ & $55-80$ & $>80$ \\
\hline $\begin{array}{l}\text { Percentage of expected number of } \\
\text { piscivorous species (PSP) }\end{array}$ & $<65$ & $65-85$ & $>85$ \\
\hline $\begin{array}{l}\text { Percentage of expected number of } \\
\text { madtom and darter species (BSP) }\end{array}$ & $<55$ & $55-80$ & $>80$ \\
\hline \multicolumn{4}{|l|}{ Species composition } \\
\hline Percent native minnows & $<20$ & $20-35$ & $>35$ \\
\hline Percent sunfish & $<5$ and $>45$ & $25-45$ & $5-24$ \\
\hline \multicolumn{4}{|l|}{ Trophic composition } \\
\hline Percent generalized insectivores & $>75$ & $50-75$ & $<50$ \\
\hline \multicolumn{4}{|l|}{ Local indicator species } \\
\hline Percent tolerant fish & $>15$ & $5-15$ & $<5$ \\
\hline \multicolumn{4}{|l|}{ Fish abundance (Number/100 m²) } \\
\hline Stream orders $1-3, \geq 4$ passes $^{b}$ & $<25$ & & $\geq 25$ \\
\hline Stream orders $1-3,1$ pass & $<10$ & & $\geq 10$ \\
\hline Stream order $4, \geq 4$ passes & $<5$ & & $\geq 5$ \\
\hline Stream order 4,1 pass & $<2$ & & $\geq 2$ \\
\hline \multicolumn{4}{|l|}{ Fish condition } \\
\hline Percent with disease or anomalies & $>5$ & $2-5$ & $<2$ \\
\hline
\end{tabular}

a Percentage determined on the basis of sample site surface area and sampling effort (Paller et al. 1996)

${ }^{\mathrm{b}}$ Passes refer to number of electrofishing passes through the sample reach 
WSRC-TR-2003-00149

Rev. 0

March 27, 2003

Table 3. Metrics and scoring criteria used in Hester-Dendy multimetric index (HDMI). Individual metrics are assigned scores of one, three, or five.

\begin{tabular}{|c|c|c|c|}
\hline \multirow[b]{2}{*}{ Metrics } & \multicolumn{3}{|c|}{ Scoring criteria } \\
\hline & 1 & 3 & 5 \\
\hline \multicolumn{4}{|l|}{ Community structure } \\
\hline Number of taxa per sampler & $\leq 2$ & $3-5$ & $\geq 6$ \\
\hline Number of $\mathrm{EPT}^{\mathrm{a}}$ taxa per sampler & $\leq 1$ & $2-3$ & $\geq 4$ \\
\hline \multicolumn{4}{|l|}{ Community balance } \\
\hline Percent Tanytarsini & $<10$ & $10-25$ & $>25$ \\
\hline Percent Trichoptera & 0 or $>10$ & & $>0-10$ \\
\hline Percent Ephemeroptera & $<10$ & $10-25$ & $>25$ \\
\hline Taxonomic similarity & $<0.15$ & $>0.15-0.30$ & $>0.30$ \\
\hline \multicolumn{4}{|l|}{ Community function } \\
\hline Functional group similarity ${ }^{c}$ & $<0.40$ & $0.40-0.60$ & $>0.60$ \\
\hline Standardized density ${ }^{d}$ & $>3.5$ & $>1.5-3.5$ & $\leq 1.5$ \\
\hline
\end{tabular}

a Ephemeroptera, Plecoptera, and Trichoptera.

b Similarity to the average taxonomic composition at the unimpacted stations (calculated with Pinkham and Pearson index)

C Similarity to the average functional group composition at the unimpacted stations (calculated with Pinkham and Pearson index)

d Standardized density $=|(X-M) / S D|$ : where $X=$ density, $M=$ average density for the unimpacted station and $\mathrm{SD}=$ standard deviation of the mean for the unimpacted stations. 
WSRC-TR-2003-00149

Rev. 0

March 27, 2003

taxa and a biotic index that reflects the relative pollution tolerances of individual taxa (Lenat, 1993). Each of these metrics is assigned a score of 1 to 5 for each site (SCDHEC 1998, Table 4), and the two scores are averaged to produce a combined bioclassification score. When the score falls between two bioclassification ratings, it is either rounded up or down based on whether the decimal fraction is larger or smaller than 0.5. If the decimal fraction was 0.5 , standard rounding procedures were used, but a + or - was added to the score to indicate that it bordered on two ratings.

Because the MHSP appeared to produce inaccurate scores in some cases, a modified version was developed by adjusting the EPT metric for stream size and adjusting the overall scoring system by calibrating it against SRS streams known to be of high-quality. Because larger streams typically support greater macroinvertebrate diversity than smaller headwater streams (Vannote et al., 1980), larger streams would be expected to have more EPT taxa than smaller streams. The EPT metric was adjusted by drawing a "maximum species richness line" (Fausch et al. 1984) through the highest points on a plot of number of EPT taxa versus stream size and dividing the area below the line into five areas of equal size corresponding to the five previously described bioclassification categories (Figure 1). In general, these adjustments increased the scores for streams of high and moderate quality, but did not affect the scores of lowquality streams. Both unmodified and modified bioclassification scores are presented and discussed in this report.

The HAl was computed using a method described by Adams et al. (1993) that consisted of assigning each variable (e.g., appearance of the liver) from each fish a numerical score based on evidence of pathology, with higher scores indicating greater pathology. Details concerning identification of pathological conditions and scoring can be found in Adams et al. (1993). The HAl for each fish was computed by summing the scores for the sixteen variables recorded for each fish. The statistical significance of differences between HAI values at potentially disturbed sites and reference sites was assessed with the Kruskal-Wallis test $(P \leq 0.05)$.

The condition factor $(\mathrm{K})$, which expresses the relationship between a fish's weight and its length, was calculated using the following formula:

$\mathrm{K}=\left(\mathrm{W} \times 10^{5}\right) / \mathrm{L}^{3}$,

where $\mathrm{W}$ equals weight in $\mathrm{g}$ and $\mathrm{L}$ equals total length in $\mathrm{mm}$. Like the $\mathrm{HAI}$, condition factors are an indicator of fish health, with low condition factors suggesting poor health. Condition was calculated for each redbreast sunfish that was necropsied for HAI determination and for many of the fish collected for tissue contaminant analysis.

For the purpose of presentation, data concerning contaminants in fish flesh were divided into two categories, radioactive constituents and nonradioactive constituents. Summary tables were constructed for those constituents (radioactive and nonradioactive) for which a majority of the values were above detection limits. This included a relatively small proportion of the measured constituents. These tables included means, maximums, and upper 95\% confidence limits (generally based on $n=3$ ) for each constituent at each site. When calculating means for nonradioactive constituents, analytical results below detection limits were considered to be equal to one half the detection limit. When calculating means for radioactive constituents, analytical 
WSRC-TR-2003-00149

Rev. 0

March 27, 2003

Table 4. Scores for EPT Taxa Richness and BI values for Sandhills/Coastal Plain Streams (from SCDHEC, 1998). SCDHEC's bioclassification rating system is Excellent $=5$, Good $=4$, Good-Fair $=3$, Fair $=2$, Poor $=1$

\begin{tabular}{ccc}
\hline Score & Biotic Index Values & Number of EPT Taxa \\
\hline 5 & $<5.42$ & $>29$ \\
4.6 & $5.42-5.46$ & 28 \\
4.4 & $5.47-5.51$ & 27 \\
4 & $5.52-6.00$ & $22-26$ \\
3.6 & $6.01-6.05$ & 21 \\
3.4 & $6.06-6.10$ & 20 \\
3 & $6.11-6.67$ & $15-19$ \\
2.6 & $6.68-6.72$ & 14 \\
2.4 & $6.73-6.77$ & 13 \\
2 & $6.78-7.68$ & $8-12$ \\
1.6 & $7.69-7.73$ & 7 \\
1.4 & $7.74-7.79$ & 6 \\
1 & $>7.79$ & $0-5$ \\
\hline
\end{tabular}


WSRC-TR-2003-00149

Rev. 0

March 27, 2003

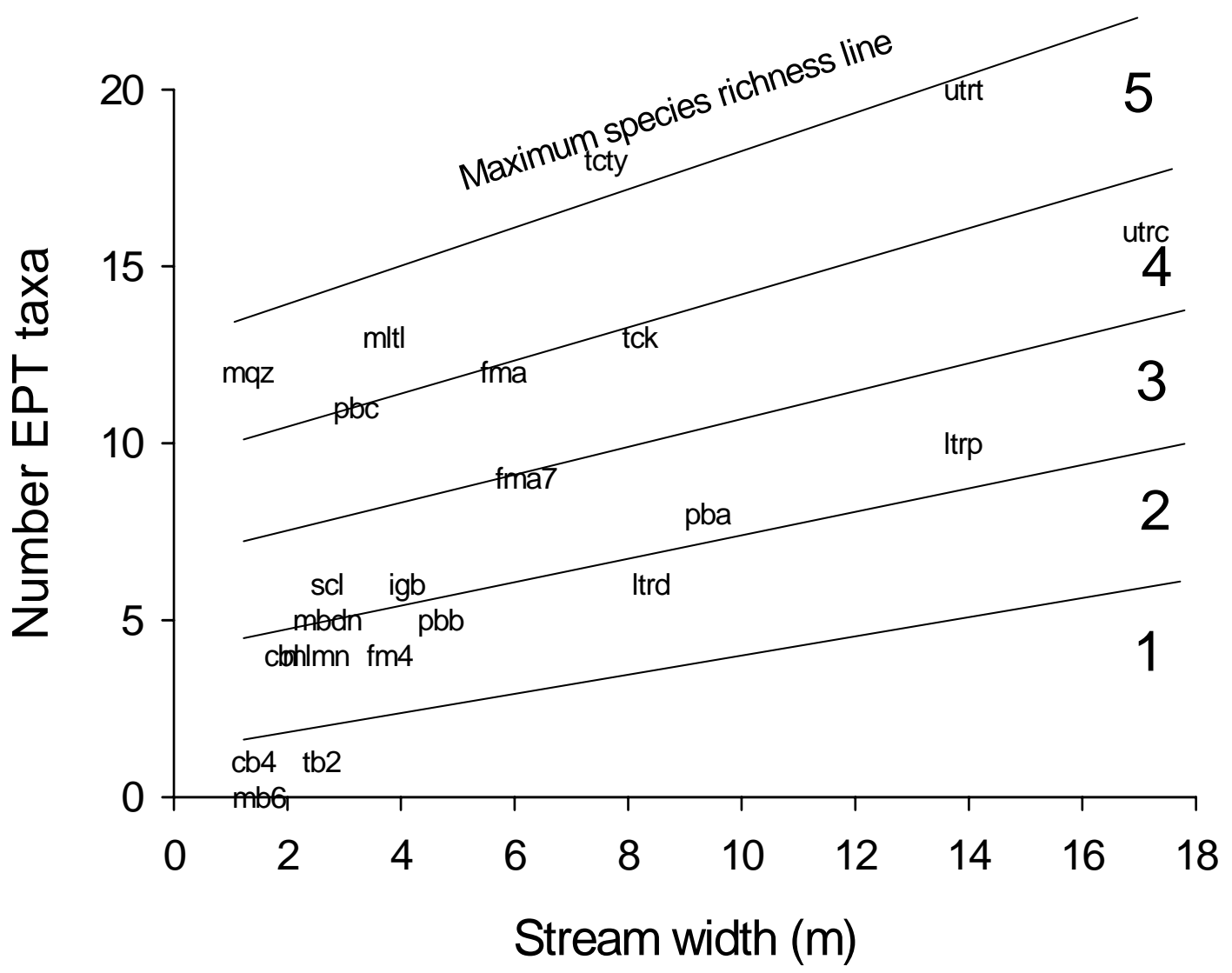

Figure 1. Relationship between number of EPT taxa and stream size. The area beneath the maximum species richness line has been subdivided to produce five bioclassification ratings. 
WSRC-TR-2003-00149

Rev. 0

March 27, 2003

results below detection limits were considered to be equal to the reported result. The formula for calculating the upper 95\% confidence interval ( $\mathrm{UCl})$ was:

$\mathrm{UCI}=\mathrm{M}+1.96(\mathrm{SE})$

where $\mathrm{M}$ is the mean and SE is the standard error. Detailed information concerning all constituents measured in this study can be found in data bases maintained by the Environmental Restoration Department of WSRC. These data are available upon request.

\section{RESULTS AND DISCUSSION}

\section{Upper Three Runs IOU}

$|B|$

Sampling for IBI determination was conducted during 1997/1998, 2000, and 2003 in the Upper Three Runs IOU. In 1997/1998, the IBI was calculated for Upper Three Runs near Tyler Bridge, Upper Three Runs near Road 8-1, Upper Three Runs near Road A.2, Crouch Branch, McQueen Branch, Tim's Branch, and Mill Creek. The IBI at Upper Three Runs near Road A.2, which was located downstream from important waste sites such as those in $\mathrm{F}$ and $\mathrm{H}$ Areas, was 37 . This value was not significantly different from the reference site IBIs (40.3-48.7, Table 5) and was within the range of IBIs for unimpacted sites in the historical data set (Figure 2). In contrast, the IBI at Upper Three Runs near Tyler Bridge (27), located upstream of all SRS NPDES outfalls and industrial areas, was significantly lower than at the four reference sites and below the values for undisturbed streams in the historical data set. This portion of the stream had extensive overhanging brush (an average of $43 \%$ of the stream surface area, Table 6 ) which made electrofishing difficult. The low conductivity of Upper Three Runs water (Halverson et al. 1997) may have also reduced electrofishing success. These factors could result in an apparent, rather than real, reduction in biotic integrity. Whether apparent or real, relatively low biotic integrity near Tyler Bridge was not the result of impacts from SRS waste sites since all SRS waste sites were located downstream from Tyler Bridge.

The IBI for Mill Creek, a reference stream, was 40, slightly below the IBI at the other three reference sites sampled during 1997(Table 4), but well within the upper half of the IBI values in the historical data set of undisturbed streams (Figure 2). IBI values at McQueen Branch and Tims Branch (39 and 39, respectively), both of which are downstream from SRS waste sites, were not significantly different from the IBIs at the reference sites and within the range of IBIs for undisturbed streams in the historical data set. However, the IBI at Crouch Branch (29) was significantly lower than the IBI at the reference sites and lower than any of the IBIs for undisturbed streams in the historical data set.

The Upper Three Runs IOU was sampled a second time during 2000. There were two changes in sampling locations between 1997 and 2000. The upstream sample station in Upper Three Runs was moved from Tyler Bridge Road to Road 8-1 because boat access was no longer possible near Tyler Bridge Road. The McQueen Branch sample station was moved from $Z$ area to Road $F$ because the stream reach near $Z$ area 
WSRC-TR-2003-00149

Rev. 0

March 27, 2003

Table 5. IBI values from stream sites located in the Upper Three Runs (UTR), Fourmile Branch (FMB), Pen Branch (PB), Steel Creek (SC), and Lower Three Runs (LTR) Integrator Operable Units (IOUs). Type refers to reference (R) or possibly impacted (PI). Three 50 $\mathrm{m}$ sections (S1, S2, S3) were electrofished at each site.

\begin{tabular}{|c|c|c|c|c|c|c|c|c|}
\hline IOU & Stream & Location & Type & S1 & S2 & S3 & Avg. & S.E. \\
\hline \multicolumn{9}{|c|}{ 1996-1998 } \\
\hline \multirow[t]{6}{*}{ UTR } & Upper Three Runs (1998) & Tyler Bridge Rd & $\mathrm{R}^{\mathrm{a}}$ & 22 & 30 & 30 & 27.3 & 2.7 \\
\hline & Upper Three Runs (1998) & $\mathrm{Rd} A .2$ & PI & 40 & 42 & 30 & 37.3 & 3.7 \\
\hline & Crouch Branch (1997) & Near UTR & $\mathrm{PI}$ & 28 & 36 & 24 & 29.3 & 3.5 \\
\hline & McQueen Branch (1997) & Z Area & PI & 44 & 42 & 30 & 38.7 & 4.4 \\
\hline & Tims Branch (1997) & $\mathrm{Rd} 2$ & PI & 40 & 38 & 38 & 38.7 & 0.7 \\
\hline & Mill Creek (1997) & Telephone Cable Rd & $\mathrm{R}$ & 44 & 44 & 40 & 42.7 & 1.3 \\
\hline \multirow{4}{*}{ FMB } & Fourmile Branch (1997) & Rd. 4 & PI & 18 & 26 & 22 & 22.0 & 2.3 \\
\hline & Fourmile Branch (1997) & Rd. C & $\mathrm{PI}$ & 36 & 46 & $\mathrm{~b}$ & 41.0 & 5.0 \\
\hline & Fourmile Branch (1997) & $\mathrm{Rd} A .6$ & PI & 42 & 48 & 38 & 42.7 & 2.9 \\
\hline & Fourmile Branch (1997) & $\mathrm{Rd} A$ & $\mathrm{PI}$ & 42 & 40 & 50 & 44.0 & 3.1 \\
\hline \multirow[t]{4}{*}{ PB } & Pen Branch (1997) & $\mathrm{Rd} C$ & $\mathrm{R}$ & 50 & 50 & 46 & 48.7 & 1.3 \\
\hline & Pen Branch (1997) & $\mathrm{Rd} B$ & $\mathrm{R}$ & 46 & 48 & 48 & 47.3 & 0.7 \\
\hline & Pen Branch (1997) & $\operatorname{Rd} A$ & $\mathrm{PI}$ & 44 & 46 & 46 & 45.3 & 0.7 \\
\hline & Indian Grave Branch (1997) & K Cooling Tower & $\mathrm{PI}$ & 44 & 46 & 44 & 44.7 & 0.7 \\
\hline \multirow[t]{8}{*}{ SC } & Steel Creek (1997) & $\mathrm{Rd} C$ & $\mathrm{PI}$ & 38 & 30 & 30 & 32.7 & 2.7 \\
\hline & Meyers Branch (1997) & Old Dunbarton Rd & $\mathrm{R}$ & 44 & 46 & 46 & 45.3 & 0.7 \\
\hline & Steel Creek (1996) & P Area & $\mathrm{PI}$ & 13 & 17 & 17 & 15.7 & 1.3 \\
\hline & Steel Creek (1996) & $\mathrm{Rd} C$ & $\mathrm{PI}$ & 19 & 19 & 27 & 21.7 & 2.7 \\
\hline & Steel Creek (1996) & $\mathrm{Rd} A$ & PI & 29 & 41 & 39 & 36.3 & 3.7 \\
\hline & Steel Creek (1996) & L Lake Dam & PI & 39 & 29 & 23 & 30.3 & 4.7 \\
\hline & Meyers Branch (1996) & Old Dunbarton Rd & $\mathrm{R}$ & 45 & 43 & 43 & 43.7 & 0.7 \\
\hline & Meyers Branch (1996) & $\mathrm{Rd} 9$ & $\mathrm{R}$ & 39 & 45 & 37 & 40.3 & 2.4 \\
\hline LTR & Lower Three Runs (1997) & $\mathrm{Rd} B$ & $\mathrm{PI}$ & 34 & 42 & 40 & 38.7 & 2.4 \\
\hline \multicolumn{9}{|c|}{2000} \\
\hline \multirow[t]{6}{*}{$\begin{array}{l}\text { UTR } \\
\end{array}$} & Upper Three Runs & $\mathrm{Rd} 8-1$ & $\mathrm{R}^{\mathrm{a}}$ & 34 & 38 & 38 & 36.7 & 1.3 \\
\hline & Upper Three Runs & $\mathrm{Rd} A .2$ & $\mathrm{PI}$ & 48 & 40 & 38 & 42.0 & 3.1 \\
\hline & Crouch Branch & Near UTR & $\mathrm{PI}$ & 46 & 42 & 44 & 44.0 & 1.2 \\
\hline & McQueen Branch & $\operatorname{Rd} F$ & $\mathrm{PI}$ & 38 & 38 & 38 & 38.0 & 0.0 \\
\hline & Tims Branch & $\mathrm{Rd} 2$ & $\mathrm{PI}$ & 40 & 30 & 36 & 35.3 & 2.9 \\
\hline & Mill Creek & Telephone Cable Rd & $\mathrm{R}$ & 48 & 46 & 48 & 47.3 & 0.7 \\
\hline \multirow[t]{3}{*}{ FMB } & Fourmile Branch & $\mathrm{Rd} \mathrm{C}$ & $\mathrm{PI}$ & 44 & 36 & 46 & 42.0 & 3.1 \\
\hline & Fourmile Branch & $\mathrm{Rd} A .6$ & $\mathrm{PI}$ & 46 & 44 & 48 & 46.0 & 1.2 \\
\hline & Fourmile Branch & $\mathrm{Rd} A$ & PI & 50 & 34 & $\mathrm{~b}$ & 42.0 & 6.5 \\
\hline \multirow[t]{4}{*}{ PB } & Pen Branch & $\mathrm{Rd} C$ & $\mathrm{R}$ & 48 & 46 & 50 & 48.0 & 1.2 \\
\hline & Pen Branch & $\mathrm{Rd} B$ & $\mathrm{R}$ & 46 & 44 & 48 & 46.0 & 1.2 \\
\hline & Pen Branch & $\mathrm{Rd} A$ & $\mathrm{PI}$ & 50 & 46 & 50 & 48.7 & 1.3 \\
\hline & Indian Grave Branch & K Cooling Tower & $\mathrm{PI}$ & 48 & 48 & 46 & 47.3 & 0.7 \\
\hline \multirow[t]{3}{*}{ SC } & Steel Creek & $\mathrm{Rd} C$ & PI & 24 & 18 & 28 & 23.3 & 2.9 \\
\hline & Steel Creek & $\mathrm{Rd} A$ & $\mathrm{PI}$ & 40 & 40 & 50 & 43.3 & 3.3 \\
\hline & Meyers Branch & Old Dunbarton Rd & $\mathrm{R}$ & 50 & 46 & 44 & 46.7 & 1.8 \\
\hline
\end{tabular}


WSRC-TR-2003-00149

Rev. 0

March 27, 2003

Table 5. continued

\begin{tabular}{lllllllll}
\hline IOU & Stream & Location & Type & S1 & S2 & S3 & Avg. & S.E. \\
\hline \multirow{2}{*}{ UTR } & Upper Three Runs & Rd 8-1 & & & & & & \\
& Upper Three Runs & Rd A.2 & $\mathrm{R}^{\mathrm{a}}$ & 30 & 34 & 30 & 31.3 & 2.3 \\
& Crouch Branch & Near UTR & $\mathrm{PI}$ & 42 & 48 & 44 & 44.7 & 1.8 \\
& McQueen Branch & Rd F & $\mathrm{PI}$ & 46 & 40 & 46 & 44.0 & 2.0 \\
& Tims Branch & Rd 2 & $\mathrm{PI}$ & 42 & 42 & 40 & 41.3 & 0.7 \\
& Mill Creek & Telephone Cable Rd & $\mathrm{PI}$ & 36 & 36 & 34 & 35.3 & 0.7 \\
& Tinker Creek & Kennedy Pond Rd & 48 & 48 & 50 & 48.7 & 0.7 \\
FMB & Fourmile Branch & $\mathrm{R}$ & 50 & 48 & 46 & 48.0 & 1.2 \\
& Fourmile Branch & Rd C & $\mathrm{PI}$ & 50 & 42 & 46 & 46.0 & 2.3 \\
& Fourmile Branch & Rd A.6 & $\mathrm{PI}$ & 50 & 50 & 40 & 46.7 & 3.3 \\
PB & Pen Branch & Rd C & $\mathrm{PI}$ & 38 & 34 & 28 & 33.3 & 2.9 \\
& Pen Branch & Rd B & $\mathrm{R}$ & 44 & 38 & 46 & 42.7 & 2.4 \\
& Pen Branch & Rd A13.2 & $\mathrm{R}$ & 42 & 46 & 50 & 46.0 & 2.3 \\
& Indian Grave Branch & K Cooling Tower & $\mathrm{PI}$ & 50 & 40 & 44 & 44.7 & 2.9 \\
SC & Steel Creek & Rd C & 38 & 48 & 46 & 44.0 & 3.1 \\
& Steel Creek & Rd A & $\mathrm{PI}$ & 24 & 18 & 32 & 24.7 & 4.1 \\
& Meyers Branch & Old Dunbarton Rd & $\mathrm{P}$ & 50 & 50 & 50 & 50.0 & 0.0 \\
LTR & Lower Three Runs & Donora Station & $\mathrm{PI}$ & 40 & 34 & 34 & 36.0 & 2.0 \\
& Lower Three Runs & Patterson Mill & $\mathrm{PI}$ & 38 & 34 & 40 & 37.3 & 1.8 \\
\hline
\end{tabular}

${ }^{a}$ Not affected by SRS discharges but not used as an IBI reference site because of poor electrofishing efficiency due to habitat and low water conductivity

b Insufficient space for three replicates 
WSRC-TR-2003-00149

Rev. 0

March 27, 2003

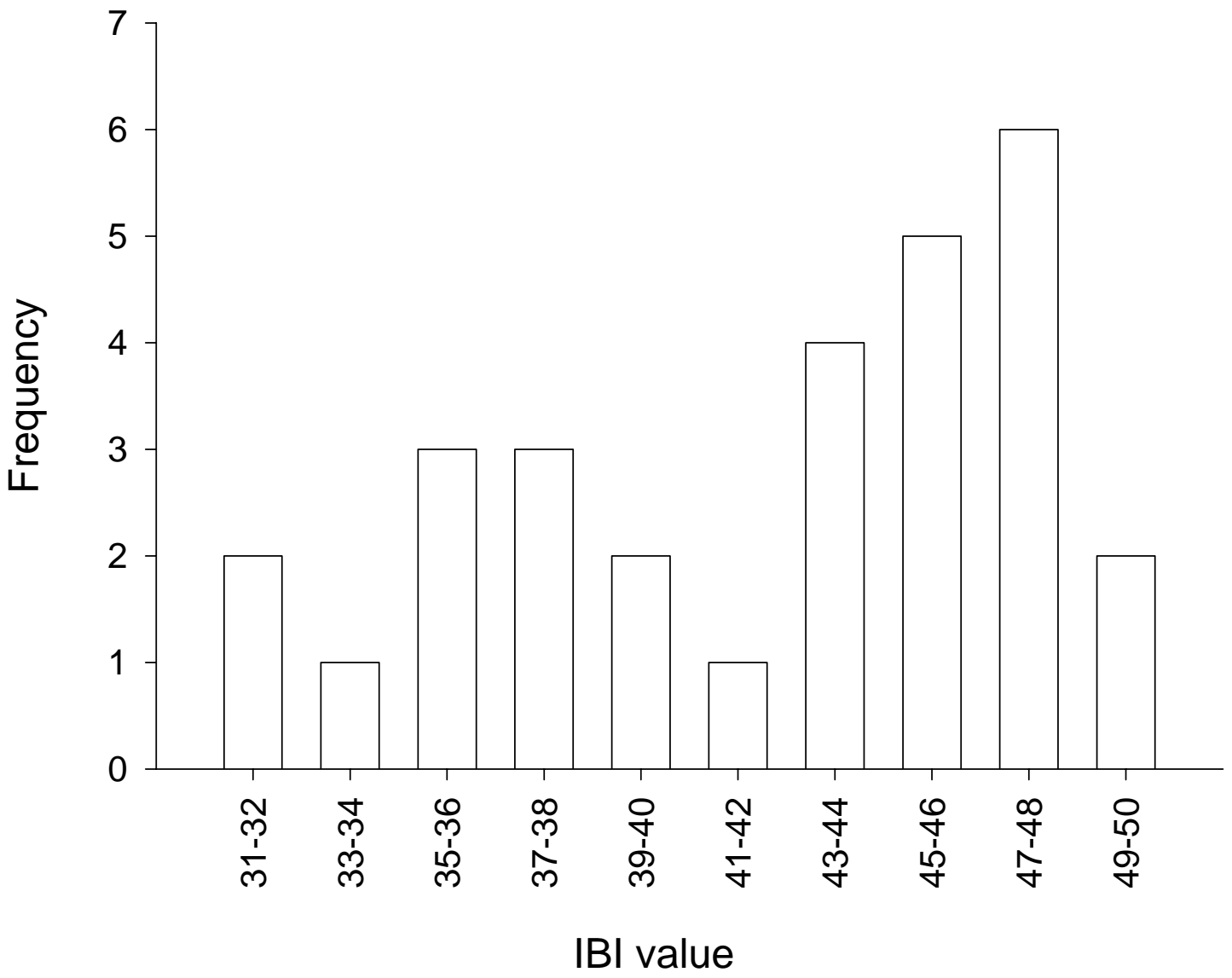

Figure 2. Frequency distribution of IBI values from 29 relatively undisturbed streams sampled during 1990-1995. 
WSRC-TR-2003-00149

Rev. 0

March 27, 2003

was impounded by beavers. The IBI was designed for use in free flowing stream reaches and would not be expected to produce accurate results in standing water habitats.

Average IBIs in Upper Three Runs during 2000 were 42.0 near Road A.2 and 36.7 near Road 8-1. (Table 5). Neither value was significantly different from the IBIs at the four control sites (46-48), and both were within the range of IBIs for unimpacted sites in the historical data set (Figure 2). However, like the IBI at Tyler Bridge Road, the IBI at Road 8-1 was substantially lower than the IBIs at the control sites in 2000 (46-48) despite the fact that it was upstream of all discharges and waste sites. Sampling was difficult near Road 8-1 because of relatively deep water, strong currents, extensive overhanging brush (Table 6), and possibly because of low conductivity suggesting that reduced sampling efficiency may have depressed the IBI at this site.

The average IBI at Mill Creek, a control stream without NPDES outfalls, was the second highest (47.3) recorded at any site in 2000 (Table 5). The average IBI in Crouch Branch (near Upper Three Runs), which receives NPDES discharges was also relatively high, averaging 44.0. In contrast, the average IBIs at McQueen Branch and Tims Branch, both of which receive NPDES discharges, were lower, averaging 38.0 and 35.3, respectively, although neither IBI significantly differed from the control sites. These moderately depressed IBIs indicate that Tims Branch and McQueen Branch did not possess the environmental quality of the reference streams. Large amounts of iron floc on the stream bed of Tims Branch suggested that habitat quality may have been diminished by the release of anoxic water from beaver ponds located upstream of the sample site. The situation in McQueen Branch was less clear. The narrow and shallow reach sampled in this stream (Tables 6 and 7) offered comparatively poor habitat compared with the reference sites and probably accounted for the low IBI at this site.

The same sites in the Upper Three Runs IOU that were electrofished in 2000 were also electrofished in 2003 (Table 1), and IBI values at these sites differed relatively little between years (Table 5). The average IBI near Tyler Bridge Road (31.3), a site located above any SRS waste sites or discharges, was significantly lower than at the reference sites (averages of 42.7-50.0). The IBI at this site was also relatively low during 2000 (36.7) as a likely consequence of poor sampling efficiency due to low conductivity of the stream water and much overhanging brush (as previously discussed). In contrast, the IBI for Upper Three Runs near Road A.2, which was downstream from SRS waste sites and potentially subject to SRS impacts, was much higher (44.7) indicating the presence of a healthy fish community. Similarly, the Crouch Branch IBI was comparatively high (average of 44.0) as was the McQueen Branch IBI (41.3)m, which showed a moderate increase from 2000 levels (38.0). The IBI for Tims Branch at Road 2 was 35.3, the same as in 2000. Although not significantly lower than the reference sites (42.7-50.0), this comparatively low value indicates that biotic integrity remained depressed in Tims Branch. The IBI for Mill Creek, a reference site located in the Upper Three Runs IOU, was very high (48.7) reflecting high biotic integrity in this largely undisturbed stream. 
WSRC-TR-2003-00149

Rev. 0

March 27, 2003

Table 6. Means for habitat variables measured in streams in the Upper Three Runs (UTR), Four Mile Branch (FMB), Pen Branch (PB), Steel Creek (SC), and Lower Three Runs (LTR) Integrator Operable Units (IOUs) during 1996-2000. Variables were measured at nine transects at each sample station except at Four Mile Creek Rd. C and Upper Three Runs Road A. 2 where variables were measured at six transects.

\begin{tabular}{|c|c|c|c|c|c|c|c|c|c|c|c|c|c|c|c|}
\hline 100 & Sample site & Location & Type $^{1}$ & $\begin{array}{l}\frac{\varepsilon}{5} \\
\frac{5}{\frac{7}{3}}\end{array}$ & $\begin{array}{l}\text { हृ } \\
\text { 竞 } \\
\text { है }\end{array}$ & 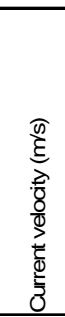 & 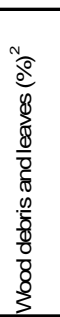 & 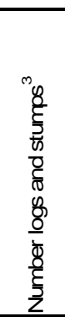 & $\begin{array}{l}\frac{0}{0} \\
\frac{0}{0} \\
\frac{0}{0} \\
\frac{0}{0} \\
\frac{0}{0} \\
\frac{0}{2}\end{array}$ & 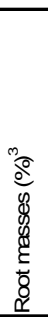 & $\begin{array}{l}\frac{m}{0} \\
\frac{0}{0} \\
\frac{8}{2} \\
\frac{0}{0} \\
\frac{0}{8} \\
\sum\end{array}$ & 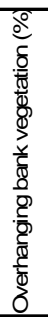 & 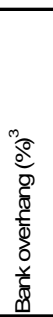 & 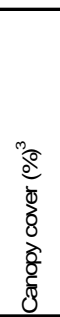 & 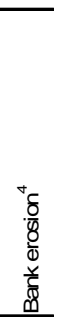 \\
\hline & Upper Three Runs (1998) & Tyler Bridge Rd & $\mathrm{R}$ & $\frac{1}{13.9}$ & $\frac{6-1998}{44.1}$ & 0.21 & 12 & 1.2 & 23 & 5 & 19 & 43 & 0 & 20 & $\overline{0.0}$ \\
\hline \multirow{5}{*}{ UTR } & Upper Three Runs (1998) & $\begin{array}{l}\text { Tyler Bridge Rd } \\
\text { Rd A.2 }\end{array}$ & $\begin{array}{l}\mathrm{R} \\
\mathrm{PI}\end{array}$ & $\begin{array}{l}13.9 \\
16.5\end{array}$ & $\begin{array}{r}44.1 \\
111.3\end{array}$ & $\begin{array}{l}0.21 \\
0.38\end{array}$ & $\begin{array}{l}12 \\
10\end{array}$ & $\begin{array}{l}1.2 \\
3.7\end{array}$ & $\begin{array}{l}23 \\
14\end{array}$ & $\begin{array}{l}5 \\
1\end{array}$ & $\begin{array}{r}19 \\
0\end{array}$ & $\begin{array}{r}43 \\
3\end{array}$ & $\begin{array}{l}0 \\
0\end{array}$ & $\begin{array}{l}20 \\
72\end{array}$ & $\begin{array}{l}0.0 \\
0.0\end{array}$ \\
\hline & Crouch Branch (1997) & $\operatorname{Rd} 4$ & $\mathrm{PI}$ & 1.4 & $\begin{array}{r}1+3 \\
6.7\end{array}$ & 0.24 & 3 & $\begin{array}{l}.1 \\
1.8\end{array}$ & $\begin{array}{r}14 \\
6\end{array}$ & 4 & 0 & 3 & 2 & 87 & 3.0 \\
\hline & McQueens Branch (1997) & Z Area & $\mathrm{PI}$ & 2.4 & 13.7 & 0.27 & 4 & 1.4 & 9 & 7 & 3 & 32 & 8 & 82 & 0.3 \\
\hline & Tims Branch (1997) & $\mathrm{Rd} 2$ & $\mathrm{PI}$ & 2.7 & 16.0 & 0.18 & 8 & 2.3 & 22 & 12 & 1 & 8 & 7 & 85 & 0.8 \\
\hline & Mill Creek (1997) & Telephone Cable Rd & $\mathrm{R}$ & 3.4 & 21.4 & 0.19 & 14 & 3.4 & 17 & 7 & 2 & 12 & 6 & 89 & 0.0 \\
\hline \multirow[t]{4}{*}{ FMB } & Four Mile Branch (1997) & $\mathrm{Rd} 4$ & $\mathrm{PI}$ & 3.8 & 35.1 & 0.08 & 4 & 3.0 & 14 & 4 & 12 & 14 & 1 & 73 & 0.1 \\
\hline & Four Mile Branch (1997) & $\mathrm{Rd} C$ & $\mathrm{PI}$ & 8.0 & 33.7 & 0.22 & 13 & 6.5 & 13 & 7 & 17 & 28 & 0 & 76 & 0.0 \\
\hline & Four Mile Branch (1997) & Rd A.7 & $\mathrm{PI}$ & 5.3 & 35.6 & 0.18 & 9 & 2.6 & 13 & 9 & 10 & 26 & 6 & 82 & 0.6 \\
\hline & Four Mile Branch (1997) & $\mathrm{Rd} A$ & $\mathrm{PI}$ & 5.1 & 64.1 & 0.12 & 17 & 4.0 & 12 & 4 & 3 & 22 & 2 & 31 & 0.0 \\
\hline \multirow[t]{4}{*}{ PB } & Pen Branch (1997) & $\mathrm{RdC}$ & $\mathrm{R}$ & $\begin{array}{l}1.1 \\
1.7\end{array}$ & 10.8 & 0.03 & 27 & 1.2 & 16 & 8 & 0 & 5 & 11 & 100 & 0.2 \\
\hline & Pen Branch (1997) & $\mathrm{Rd} \mathrm{B}$ & $\mathrm{R}$ & 4.3 & 9.5 & 0.16 & 5 & 2.2 & 9 & 6 & 0 & 11 & 3 & 85 & 0.1 \\
\hline & Pen Branch (1997) & $\mathrm{Rd} \mathrm{A}$ & $\mathrm{PI}$ & 9.4 & 37.4 & 0.11 & 3 & 2.8 & 6 & 2 & 59 & 22 & 1 & 38 & 0.0 \\
\hline & Indian Grave Branch (1997) & K Cooling Tower & $\mathrm{PI}$ & 5.2 & 35.3 & 0.12 & 3 & 2.9 & 8 & 3 & 9 & 19 & 2 & 51 & 0.8 \\
\hline \multirow[t]{8}{*}{ sc } & $\begin{array}{l}\text { Steel Creek (1997) } \\
\text { (1997) }\end{array}$ & Rd B & $\mathrm{PI}$ & $\begin{array}{l}3.2 \\
3.1\end{array}$ & $\begin{array}{l}35.3 \\
12.8\end{array}$ & 0.14 & 13 & 1.2 & 12 & 6 & 4 & 10 & 4 & 72 & 2.0 \\
\hline & Meyers Branch (1997) & Old Dunbarton Rd & $\mathrm{R}$ & 2.9 & 12.4 & 0.36 & 13 & 1.6 & 22 & 10 & 0 & 5 & 4 & 93 & 0.4 \\
\hline & $\begin{array}{l}\text { Steel Creek (1996) } \\
\text { (1996) }\end{array}$ & $\begin{array}{l}\text { P Area } \\
\text {. }\end{array}$ & $\mathrm{PI}$ & 4.7 & $\begin{array}{l}26.4 \\
26.4\end{array}$ & 0.33 & 5 & $\begin{array}{l}1.0 \\
1.3\end{array}$ & 5 & 5 & 4 & 13 & 5 & 56 & $\begin{array}{l}2.4 \\
2.2\end{array}$ \\
\hline & Steel Creek (1996) & $\mathrm{Rd} C$ & $\mathrm{PI}$ & 4.4 & 23.7 & 0.37 & 8 & 0.8 & 8 & 2 & 0 & 4 & 2 & 53 & 2.1 \\
\hline & Steel Creek (1996) & $\mathrm{Rd} A$ & $\mathrm{PI}$ & 11.1 & 54.3 & 0.27 & 13 & 1.3 & 6 & 2 & 20 & 12 & 2 & 25 & 0.3 \\
\hline & Steel Creek (1996) & L Lake Dam & $\mathrm{PI}$ & 11.0 & 44.6 & 0.36 & $\begin{array}{r}13 \\
9\end{array}$ & 12.9 & 17 & 1 & 3 & 9 & 3 & 8 & 0.1 \\
\hline & Meyers Branch (1996) & Old Dunbarton Rd & $\mathrm{R}$ & 3.8 & 19.0 & 0.17 & 16 & 1.4 & 16 & 4 & 0 & 13 & 3 & 81 & 0.9 \\
\hline & Meyers Branch (1996) & Rd 9 & $\mathrm{R}$ & 4.9 & 24.1 & 0.22 & 13 & 4.8 & 15 & 2 & 0 & 21 & 2 & 81 & 1.2 \\
\hline LTR & Lower Three Runs (1997) & $\mathrm{Rd} \mathrm{B}$ & $\mathrm{PI}$ & 7.7 & 61.8 & 0.35 & 15 & 4.3 & 23 & 3 & 1 & 16 & 1 & 62 & 0.0 \\
\hline & & & & & 2000 & & & & & & & & & & \\
\hline \multirow[t]{6}{*}{ UTR } & Upper Three Runs & $\mathrm{Rd} 8-1$ & $\mathrm{R}$ & 11.9 & 46.1 & 0.37 & 10 & 1.5 & 15 & 3 & 24 & 27 & 0.3 & 49 & $\overline{0}$ \\
\hline & Upper Three Runs & Rd A.2 & $\mathrm{PI}$ & 14.6 & 102.3 & 0.45 & 13 & 4.1 & 18 & 0.8 & 0 & 2 & 0 & 75 & 0 \\
\hline & Crouph Branch & Rd 4 & $\mathrm{PI}$ & 20 & 14 & 065 & 4 & 21 & 4 & 5 & 0 & 3 & 3 & 92 & 13 \\
\hline & McQueens Branch & $\mathrm{Rd} \mathrm{F}$ & $\mathrm{PI}$ & 1.6 & 10.9 & 0.17 & 4 & 1.8 & 7 & 8 & 0 & 1 & 12 & 95 & 1.9 \\
\hline & $\begin{array}{l}\text { Tims Branch } \\
\text { Timen }\end{array}$ & $\operatorname{Rd} 2$ & $\mathrm{PI}$ & $\begin{array}{l}1.6 \\
1.4\end{array}$ & $\begin{array}{l}10.9 \\
11.0\end{array}$ & 0.33 & 7 & $\begin{array}{l}1.8 \\
0.9\end{array}$ & 6 & 17 & 1 & 3 & $\begin{array}{r}12 \\
2\end{array}$ & 91 & $\begin{array}{l}0.7 \\
0.7-1\end{array}$ \\
\hline & Mill Creek & Telephone Cable Rd & $\mathrm{R}$ & 4.0 & 21.9 & 0.50 & 16 & 3.0 & 4 & 6 & 0 & 4 & 2 & 84 & 0.6 \\
\hline \multirow[t]{3}{*}{ FMB } & Four Mile Branch & Rd C & $\mathrm{PI}$ & 7.3 & 19.1 & 0.35 & 11 & 7.4 & 11 & 6 & 3 & 6 & 1 & 88 & 0.8 \\
\hline & Four Mile Branch & Rd A-6 & $\mathrm{PI}$ & 5.2 & $\begin{array}{l}19.1 \\
44.4\end{array}$ & $\begin{array}{l}0.35 \\
0.38\end{array}$ & $\begin{array}{l}11 \\
16\end{array}$ & $\begin{array}{l}. .4 \\
2.4\end{array}$ & $\begin{array}{r}11 \\
6\end{array}$ & $\begin{array}{l}6 \\
8\end{array}$ & 19 & 13 & 4 & 54 & 1.1 \\
\hline & Four Mile Branch & $\mathrm{Rd} \mathrm{A}$ & $\mathrm{PI}$ & 5.8 & 47.8 & 0.48 & 5 & 2.1 & 8 & 2 & 13 & 13 & 1 & 42 & 0.0 \\
\hline \multirow{4}{*}{ PB } & Pen Branch & $\mathrm{Rd} C$ & $\mathrm{R}$ & 1.6 & 14.3 & 0.03 & 51 & 2.3 & 9 & 8 & 0 & 2 & 10 & 95 & 0.1 \\
\hline & Pen Branch & Rd B & $\mathrm{R}$ & $\begin{array}{l}1.6 \\
3.6\end{array}$ & $\begin{array}{l}14.3 \\
11.7\end{array}$ & $\begin{array}{l}0.03 \\
0.10\end{array}$ & $\begin{array}{r}51 \\
4\end{array}$ & $\begin{array}{l}2.3 \\
1.7\end{array}$ & $\begin{array}{l}9 \\
8\end{array}$ & 4 & 0 & 7 & 2 & 87 & $\begin{array}{l}0.1 \\
0.3\end{array}$ \\
\hline & Pen Branch & Rd A13.2 & $\mathrm{PI}$ & 6.0 & 37.6 & 0.36 & 4 & 1.0 & 7 & 1 & 10 & 20 & 0 & 28 & 0.0 \\
\hline & Indian Grave Branch & K Cooling Tower & $\mathrm{PI}$ & 4.9 & 30.7 & 0.16 & 6 & 3.1 & 9 & 2 & 10 & 17 & 2.2 & 58 & 0.6 \\
\hline \multirow[t]{3}{*}{ sc } & Steel Creek & Rd C & $\mathrm{PI}$ & 2.3 & 12.1 & 0.31 & 3 & 1.2 & 7 & 11 & 0 & 6 & 5 & 91 & 1.9 \\
\hline & Steel Creek & $\mathrm{Rd} \mathrm{A}$ & $\mathrm{PI}$ & 7.9 & 40.4 & 0.36 & 4 & 1.0 & 6 & 3 & 29 & 6 & 0 & 42 & 0.1 \\
\hline & Meyers Branch & Old Dunbarton Rd & $\mathrm{R}$ & 2.9 & 15.6 & 0.25 & 10 & 2.3 & 14 & 4 & 0 & 3 & 3 & 97 & 0.3 \\
\hline
\end{tabular}

${ }^{1}$ Reference (R) and potentially impacted (PI)

${ }^{2}$ Percent variables refer to percent of stream bottom area covered by or overhung by the indicated variable

${ }^{3}$ Number of logs and stumps within a $3 \mathrm{~m}$ band on either side of the transect (6 $\mathrm{m}$ in total).

${ }^{4}$ Estimated on a scale of 0-3 with 3 most severe 
WSRC-TR-2003-00149

Rev. 0

March 27, 2003

Table 7. Means for habitat variables measured in streams in the Upper Three Runs (UTR), Four Mile Branch (FMB), Pen Branch (PB), Steel Creek (SC), and Lower Three Runs (LTR) Integrator Operable Units (IOUs) during 2003. Variables were measured at nine transects at each sample station except at Four Mile Creek Rd. C and Upper Three Runs Road A.2 where variables were measured at six transects.

\begin{tabular}{|c|c|c|c|c|c|c|c|c|c|c|c|c|c|}
\hline 100 & Sample site & Location & Type $^{1}$ & $\begin{array}{l}\widehat{\Xi} \\
\text { 言 } \\
\text { 妾 }\end{array}$ & 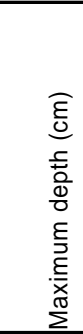 & 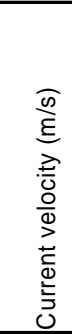 & 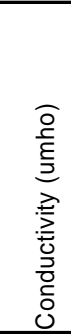 & $\frac{I}{2}$ & 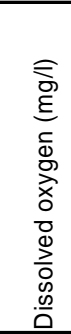 & 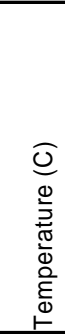 & 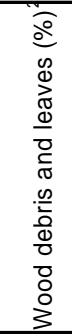 & 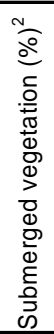 & 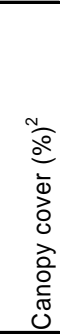 \\
\hline & & & & & 2003 & & & & & & & & \\
\hline \multirow[t]{6}{*}{ UTR } & Upper Three Runs & $\mathrm{Rd} \mathrm{A.2}$ & $\mathrm{PI}$ & 17.1 & 132.0 & 0.45 & 14.7 & 6.8 & 95.9 & 7.9 & 54.2 & 2.5 & 7.5 \\
\hline & Crouch Branch & Near Rd 4 & $\mathrm{PI}$ & 1.9 & 12.5 & 0.54 & 37.8 & 6.7 & 89.7 & 17.5 & 4.2 & 0.0 & 87.5 \\
\hline & McQueens Branch & $\mathrm{Rd} \mathrm{F}$ & $\mathrm{PI}$ & 1.3 & 28.4 & 0.42 & 43.0 & 5.5 & 80.1 & 20.8 & 5.8 & 0.0 & 87.5 \\
\hline & Tims Branch & $\mathrm{Rd} 2$ & $\mathrm{PI}$ & 2.7 & & 0.27 & 49.1 & 6.3 & 59.1 & 18.7 & 12.5 & 2.5 & 87.5 \\
\hline & Mill Creek & Telephone Cable Rd & $\mathrm{R}$ & 3.7 & 57.3 & 0.29 & 57.1 & 7.0 & 75.4 & 20.6 & 10.0 & 0.0 & 87.5 \\
\hline & Tinker Creek & Kennedy Pond Rd & $\mathrm{R}$ & 8.2 & 54.0 & 0.26 & 23.8 & 6.3 & 79.9 & 14.8 & 62.5 & 0.6 & 54.2 \\
\hline \multirow[t]{3}{*}{ FMB } & Four Mile Branch & $\mathrm{Rd} C$ & $\mathrm{PI}$ & & & 0.24 & 42.6 & 6.7 & 68.3 & 13.8 & 10.8 & 1.7 & 87.5 \\
\hline & Four Mile Branch & $\mathrm{Rd} A-6$ & $\mathrm{PI}$ & 6.2 & 85.8 & 0.30 & 63.9 & 6.8 & 68.6 & 20.3 & 17.5 & 2.5 & 87.5 \\
\hline & Four Mile Branch & $\mathrm{Rd} A$ & $\mathrm{PI}$ & 5.8 & 50.5 & 0.40 & 50.0 & 6.7 & 78.9 & 16.3 & 62.5 & 9.2 & 17.5 \\
\hline \multirow[t]{4}{*}{ PB } & Pen Branch & $\mathrm{Rd} C$ & $\mathrm{R}$ & 3.2 & 43.7 & 0.31 & 31.2 & 6.4 & 74.7 & 21.4 & 62.5 & 2.5 & 87.5 \\
\hline & Pen Branch & $\mathrm{Rd} \mathrm{B}$ & $\mathrm{R}$ & 4.7 & 42.0 & 0.37 & 40.9 & 6.1 & 79.9 & 20.0 & 2.5 & 0.0 & 87.5 \\
\hline & Pen Branch & $\mathrm{Rd} A 13.2$ & $\mathrm{PI}$ & 8.1 & 42.0 & 0.43 & 53.0 & 7.1 & 88.5 & 14.9 & 5.8 & 2.5 & 20.8 \\
\hline & Indian Grave Branch & K Cooling Tower & $\mathrm{PI}$ & 4.1 & 57.0 & 0.39 & 76.0 & 7.1 & 89.7 & 18.4 & 17.5 & 7.6 & 4.2 \\
\hline \multirow[t]{3}{*}{ SC } & Steel Creek & $\mathrm{Rd} \mathrm{C}$ & $\mathrm{PI}$ & 2.7 & 41.2 & 0.26 & 28.2 & 6.8 & 80.2 & 14.8 & 4.2 & 0.8 & 87.5 \\
\hline & Steel Creek & $\mathrm{Rd} \mathrm{A}$ & PI & 7.6 & 44.3 & 0.28 & 51.2 & 7.0 & 82.1 & 18.1 & 17.5 & 1.1 & 25.8 \\
\hline & Meyers Branch & Old Dunbarton Rd & $\mathrm{R}$ & 2.7 & 32.5 & 0.28 & 38.1 & 6.3 & 76.9 & 15.3 & 62.5 & 2.5 & 87.5 \\
\hline \multirow[t]{2}{*}{ LTR } & Lower Three Runs & Donora Station & $\mathrm{PI}$ & 8.4 & 55.1 & 0.29 & 46.8 & 6.4 & 73.1 & 19.7 & 12.5 & 1.9 & 87.5 \\
\hline & Lower Three Runs & Patterson Mill & $\mathrm{PI}$ & 13.9 & 129.7 & 0.19 & 56.6 & 7.1 & 83.4 & 9.9 & 17.5 & 2.5 & 30.8 \\
\hline
\end{tabular}

${ }^{1}$ Reference (R) and potentially impacted (PI)

${ }^{2}$ Percent variables refer to percent of stream bottom area covered by or overhung by the indicated variable 
WSRC-TR-2003-00149

Rev. 0

March 27, 2003

\section{$H A I$ and $K$}

The average HAl for the 10 redbreast sunfish collected during 1997 from Mill Creek, an undisturbed tributary of Tinker Creek, was 23 (Table 8). This value was considerably lower than the average HAI (72) from Meyers Branch, the other undisturbed reference site (low HAls indicate good health). This difference between reference cites indicates substantial variability in the frequency of pathologies among fish from undisturbed streams. The average value for lower Upper Three Runs (near Road A.2) was 67. The HAl values for fish from lower Upper Three Runs were not significantly different from the HAI values for fish from the reference sites $(P<0.05)$ indicating no increase in pathology in fish from the portion of Upper Three Runs potentially subject to waste site discharge.

An analysis of condition factors $(\mathrm{K})$ also failed to show any indication of poor health among redbreast sunfish from Upper Three Runs (Table 8). The average $\mathrm{K}$ for redbreast sunfish from Upper Three Runs near Road A.2 was 1.90, which compares favorable with the average condition factors in the reference streams, Meyers Branch (1.50) and Mill Creek (1.62) (high condition factors suggest good health) (Table 8). The Kruskal- Wallis test indicated no significant difference between condition factors for fish from Upper Three Runs near Road A.2 and fish from the reference streams.

\section{Tissue contaminants}

Fish were collected for tissue analysis from four locations in the Upper Three Runs IOU (Tinker Creek, Upper Three Runs near Tyler Bridge, Upper Three Runs near Road C, and Upper Three Runs near Road A.2) during 1998. Species collected for analysis included spotted sucker, redbreast sunfish, and chain pickerel near Tyler Bridge; bluegill, chain pickerel, striped bass, spotted sucker, redbreast sunfish, and largemouth bass near Road C; and spotted sucker, redbreast sunfish, and bowfin near Road A.2 (Tables 9 and 10). Most of the constituents measured in fish from Upper Three Runs, as well as the other locations included in this study, were below detection limits. Exceptions among the radioactive constituents included cesium-137, nonvolatile beta, plutonium-238, potassium-40, strontium-90, tritium, uranium-233/234, and uranium-238 (Table 9). The only radioactive constituent in the Upper Three Runs IOU that was elevated above reference site levels was tritium was near Road A.2. However, concentrations were much lower than in fish from Fourmile Branch and Pen Branch near Road A (Table 9).

Nonradioactive constituents commonly above detection limits in at least some IOUs included acetone, total barium, copper, dichloromethane, total managanese, total mercury, selenium, toluene, and zinc (Table 10). However, only acetone, dichloromethane, and toluene were high in fish from Upper Three Runs compared with fish from the other streams (Table 10). The greatest elevation was exhibited by dichloromethane. This constituent was elevated upstream from the SRS waste sites (Tyler Bridge Road) as well as downstream from them (Road C and Road A.2). Examination of laboratory quality assurance and control records indicated that dichloromethane was present in the methods blanks as well as the fish samples (EPD 1998). Therefore, its presence in Upper Three Runs fish probably represents laboratory contamination. The same applies to acetone, which was also found in the methods blanks. Although not reported from the methods blanks, toluene is a common laboratory material and its presence in fish from Upper Three Runs near Road C may also represent laboratory contamination. 
WSRC-TR-2003-00149

Rev. 0

March 27, 2003

Table 8. Health assessment index ( $\mathrm{HAl})$ and condition factors $(\mathrm{K})$ for redbreast sunfish collected from stream sites in the Integrator Operable Units (IOUs). Station types include reference (R) and possibly impacted (PI).

\begin{tabular}{|c|c|c|c|c|c|c|c|c|c|}
\hline Stream & Location & Type & $\mathrm{n}$ & Mean & Median & Max & Min & Stdev. & $95 \% \mathrm{Cl}$ \\
\hline \multicolumn{10}{|c|}{ Health Assessment Index (HAI) } \\
\hline Meyers Branch & Old Dunbarton Rd. & $\mathrm{R}$ & 6 & 71.7 & 70 & 90 & 60 & 13.3 & $61.0-82.3$ \\
\hline Upper Three Runs & Tyler Bridge Rd. & $\mathrm{R}$ & 10 & 23.0 & 15 & 70 & 0 & 22.1 & $9.3-36.7$ \\
\hline Upper Three Runs & Rd. A.2 & $\mathrm{PI}$ & 10 & 67.0 & 60 & 110 & 10 & 32.0 & $47.2-86.8$ \\
\hline Pen Branch & Rd. A & $\mathrm{PI}$ & 13 & 36.2 & 30 & 60 & 20 & 11.9 & $29.7-42.6$ \\
\hline Steel Creek & Rd. C & $\mathrm{PI}$ & 13 & 48.5 & 50 & 70 & 30 & 11.4 & $42.3-54.7$ \\
\hline Steel Creek & L Lake Dam & $\mathrm{PI}$ & 10 & 42.0 & 35 & 100 & 10 & 28.2 & $24.5-59.5$ \\
\hline Lower Three Runs & Rd. B & $\mathrm{PI}$ & 12 & 16.7 & 10 & 50 & 0 & 14.4 & $8.5-24.8$ \\
\hline Fourmile Branch & Rd. A & $\mathrm{PI}$ & 9 & 30.0 & 30 & 50 & 10 & 11.2 & $22.7-37.3$ \\
\hline Savannah R. Swamp & Steel Creek Area & $\mathrm{Pl}$ & 10 & 41.0 & 45 & 80 & 10 & 21.3 & $27.8-54.2$ \\
\hline \multicolumn{10}{|c|}{ Condition Factor (K) } \\
\hline Meyers Branch & Old Dunbarton Rd. & $\mathrm{R}$ & 6 & 1.50 & 1.49 & 1.68 & 1.36 & 0.11 & $1.41-1.58$ \\
\hline Upper Three Runs & Tyler Bridge Rd. & $\mathrm{R}$ & 10 & 1.62 & 1.60 & 1.79 & 1.53 & 0.07 & $1.57-1.66$ \\
\hline Upper Three Runs & $\mathrm{Rd} A .2$ & $\mathrm{PI}$ & 10 & 1.90 & 1.94 & 2.21 & 1.52 & 0.22 & $1.77-2.04$ \\
\hline Pen Branch & Rd. A & $\mathrm{PI}$ & 13 & 1.45 & 1.45 & 1.66 & 1.21 & 0.11 & $1.39-1.51$ \\
\hline Steel Creek & $\mathrm{Rd} C$ & $\mathrm{PI}$ & 13 & 1.42 & 1.44 & 1.62 & 1.25 & 0.11 & $1.36-1.48$ \\
\hline Steel Creek & L Lake Dam & $\mathrm{PI}$ & 10 & 1.54 & 1.52 & 1.69 & 1.33 & 0.13 & $1.46-1.61$ \\
\hline Lower Three Runs & Rd. B & $\mathrm{PI}$ & 12 & 1.53 & 1.46 & 2.03 & 1.33 & 0.20 & $1.41-1.64$ \\
\hline Fourmile Branch & Rd. A & $\mathrm{PI}$ & 9 & 1.44 & 1.45 & 1.47 & 1.40 & 0.02 & $1.43-1.46$ \\
\hline Savannah R. Swamp & Steel Creek Area & $\mathrm{Pl}$ & 10 & 1.89 & 1.86 & 2.09 & 1.74 & 0.13 & 1.81-1.97 \\
\hline
\end{tabular}


WSRC-TR-2003-00149

Rev. 0

March 27, 2003

Table 9. Radioactive constituents (pc/g) commonly above detection limits in fish from the Savannah River Site Integrator Operable Units. Station types include potentially influenced by SRS operations (PI) and reference (R)

\begin{tabular}{|c|c|c|c|c|c|c|c|c|c|c|c|c|c|c|}
\hline $\mathrm{IOU}$ & Stream & Location & Year & 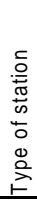 & 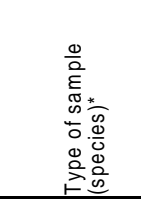 & $\begin{array}{l}\hat{m} \\
\stackrel{1}{1} \\
\underline{\Xi} \\
\vec{n} \\
0 \\
0\end{array}$ & $\begin{array}{l}\frac{\pi}{0} \\
0 \\
0 \\
0 \\
0 \\
\frac{0}{0} \\
0 \\
2 \\
0 \\
2 \\
z\end{array}$ & 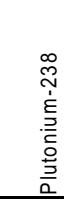 & 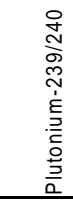 & 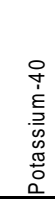 & 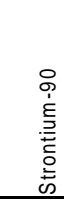 & 壱 & 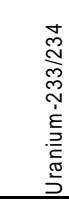 & 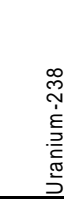 \\
\hline \multirow[t]{12}{*}{$\overline{F M C}$} & Four Mile Branch & Rd. A & 1997 & $\mathrm{PI}$ & whole fish & & & & & & & & & \\
\hline & Mean & & & & (ss, rbsf, cp) & 1.60 & 13.21 & 0.009 & -0.001 & 3.41 & 6.11 & 201.75 & 0.005 & 0.006 \\
\hline & $\operatorname{Max}$ & & & & & 1.95 & 22.70 & 0.035 & 0.003 & 3.83 & 9.92 & 208.00 & 0.007 & 0.018 \\
\hline & Upper 95\% CL & & & & & 1.93 & 23.43 & 0.027 & 0.002 & 3.69 & 10.69 & 210.89 & 0.007 & 0.016 \\
\hline & Four Mile Branch & Rd. A & 2001 & $\mathrm{PI}$ & fillet & & & & & & & & & \\
\hline & Mean & & & & (rbsf, bhc, fbh) & 1.73 & 13.66 & 0.003 & 0.002 & 3.08 & 5.14 & 17.93 & 0.028 & 0.009 \\
\hline & $\operatorname{Max}$ & & & & & 2.10 & 14.46 & 0.006 & 0.009 & 3.26 & 6.60 & 18.27 & 0.056 & 0.019 \\
\hline & Upper 95\% CL & & & & & 2.30 & 14.46 & 0.006 & 0.009 & 3.26 & 6.57 & 18.31 & 0.059 & 0.019 \\
\hline & Four Mile Branch & Rd. A13.2 & 2001 & $\mathrm{PI}$ & whole fish & & & & & & & & & \\
\hline & Mean & & & & (ccs, rbsf, ybh) & 1.87 & 12.43 & 0.001 & -0.001 & 3.51 & 5.02 & 18.37 & 0.007 & 0.007 \\
\hline & $\operatorname{Max}$ & & & & & 2.60 & 13.60 & 0.004 & 0.000 & 4.20 & 5.56 & 19.00 & 0.013 & 0.010 \\
\hline & Upper 95\% CL & & & & & 2.72 & 13.99 & 0.004 & 0.000 & 4.22 & 5.69 & 19.03 & 0.013 & 0.012 \\
\hline \multirow[t]{12}{*}{ LTR } & Lower Three Runs & Rd. B & 1997 & $\mathrm{PI}$ & whole fish & & & & & & & & & \\
\hline & Mean & & & & (rbsf, Ing, fbh) & 3.49 & 3.93 & 0.023 & 0.002 & 3.29 & 0.14 & 0.50 & 0.014 & 0.001 \\
\hline & Max & & & & & 8.07 & 6.19 & 0.030 & 0.004 & 3.71 & 0.62 & 0.61 & 0.042 & 0.009 \\
\hline & Upper 95\% CL & & & & & 6.51 & 6.43 & 0.033 & 0.004 & 3.67 & 0.47 & 0.64 & 0.041 & 0.009 \\
\hline & Lower Three Runs & Stinson Bridge & 2001 & $\mathrm{PI}$ & whole fish & & & & & & & & & \\
\hline & Mean & & & & (Imb, rbsf, ss) & 2.39 & 3.51 & 0.001 & 0.001 & 2.97 & 0.07 & 0.66 & 0.010 & 0.001 \\
\hline & Max & & & & & 2.77 & 4.31 & 0.002 & 0.002 & 3.11 & 0.14 & 0.69 & 0.026 & 0.004 \\
\hline & Upper 95\% CL & & & & & 3.07 & 4.34 & 0.002 & 0.002 & 3.21 & 0.17 & 0.70 & 0.026 & 0.006 \\
\hline & Lower Three Runs & HW 125 & 2001 & $\mathrm{PI}$ & fillet & & & & & & & & & \\
\hline & Mean & & & & (Imb, resf, ss) & 0.84 & 3.28 & 0.001 & 0.001 & 2.78 & 0.00 & 0.36 & 0.016 & -0.001 \\
\hline & Max & & & & & 1.33 & 4.70 & 0.002 & 0.002 & 3.24 & 0.10 & 0.39 & 0.052 & 0.007 \\
\hline & Upper 95\% CL & & & & & 1.43 & 4.35 & 0.002 & 0.002 & 3.10 & 0.07 & 0.39 & 0.039 & 0.006 \\
\hline \multirow[t]{12}{*}{ PB } & Pen Branch & Rd. B & 1997 & $\mathrm{R}$ & whole fish & & & & & & & & & \\
\hline & Mean & & & & (bhc, ss, rbsf) & 0.07 & 3.90 & 0.004 & 0.001 & 2.97 & -0.02 & 0.69 & 0.001 & 0.005 \\
\hline & Max & & & & & 0.11 & 4.75 & 0.017 & 0.003 & 3.38 & 0.03 & 0.80 & 0.007 & 0.013 \\
\hline & Upper 95\% CL & & & & & 0.11 & 4.87 & 0.013 & 0.003 & 3.37 & 0.03 & 0.76 & 0.006 & 0.012 \\
\hline & Pen Branch & Rd. A & 1997 & PI & whole fish & & & & & & & & & \\
\hline & Mean & & & & (ss, rbsf, Ing) & 0.08 & 9.54 & 0.013 & -0.005 & 2.70 & 2.68 & 96.48 & 0.006 & 0.011 \\
\hline & Max & & & & & 0.16 & 29.10 & 0.026 & 0.000 & 3.12 & 9.08 & 113.00 & 0.017 & 0.026 \\
\hline & Upper 95\% CL & & & & & 0.13 & 22.52 & 0.023 & 0.001 & 3.09 & 6.87 & 107.73 & 0.012 & 0.019 \\
\hline & Pen Branch & $\mathrm{Rd} A 13.2$ & 2001 & PI & whole fish & & & & & & & & & \\
\hline & Mean & & & & (ss, rbsf, Ing) & 0.09 & 2.81 & 0.010 & 0.001 & 2.52 & 0.40 & 31.97 & 0.010 & 0.002 \\
\hline & Max & & & & & 0.15 & 3.37 & 0.041 & 0.004 & 3.71 & 0.71 & 33.15 & 0.024 & 0.007 \\
\hline & Upper 95\% CL & & & & & 0.14 & 3.38 & 0.030 & 0.003 & 3.67 & 0.69 & 32.77 & 0.021 & 0.006 \\
\hline \multirow[t]{16}{*}{ SC } & Meyers Branch & Rd. 9 & 1996 & $\mathrm{R}$ & whole fish & & & & & & & & & \\
\hline & Mean & & & & (rbsf, bhc, ssf) & 0.20 & 3.54 & 0.070 & 0.013 & 3.26 & 0.13 & 0.03 & 0.037 & 0.007 \\
\hline & Max & & & & & 0.28 & 5.46 & 0.080 & 0.030 & 3.80 & 0.20 & 0.04 & 0.050 & 0.010 \\
\hline & Upper 95\% CL & & & & & 0.30 & 5.42 & 0.090 & 0.031 & 3.89 & 0.21 & 0.04 & 0.063 & 0.013 \\
\hline & Steel Creek & $\mathrm{Rd}$. B & 1996 & PI & whole fish & & & & & & & & & \\
\hline & Mean & & & & (rbsf, fbh, gs) & 2.46 & 5.66 & 0.023 & -0.020 & 3.15 & 0.26 & 1.97 & 0.038 & 0.020 \\
\hline & $\operatorname{Max}$ & & & & & 2.87 & 8.43 & 0.050 & 0.010 & 4.25 & 0.47 & 4.93 & 0.080 & 0.030 \\
\hline & Upper $95 \% \mathrm{CL}$ & & & & & 2.89 & 8.59 & 0.495 & 0.014 & 4.25 & 0.53 & 3.43 & 0.060 & 0.027 \\
\hline & Steel Creek & $\mathrm{Rd}$. A & 1996 & PI & whole fish & & & & & & & & & \\
\hline & Mean & & & & (Imb, rbsf, ss) & 1.44 & 4.40 & 0.043 & -0.003 & 3.67 & 0.49 & 0.76 & 0.030 & 0.017 \\
\hline & $\operatorname{Max}$ & & & & & 2.29 & 5.35 & 0.090 & 0.000 & 4.22 & 1.14 & 0.84 & 0.060 & 0.030 \\
\hline & Upper $95 \% \mathrm{CL}$ & & & & & 2.30 & 5.58 & 0.089 & 0.003 & 4.23 & 1.13 & 0.84 & 0.060 & 0.030 \\
\hline & Steel Creek & Floodplain swamp & 1997 & $\mathrm{PI}$ & whole fish & & & & & & & & & \\
\hline & Mean & & & & (ybh, resf, bf, & 0.98 & 3.38 & 0.022 & 0.001 & 2.95 & 0.23 & 13.75 & 0.004 & 0.006 \\
\hline & $\operatorname{Max}$ & & & & ss, Imb, rbsf, & 2.44 & 5.29 & 0.086 & 0.009 & 3.49 & 0.35 & 19.30 & 0.015 & 0.036 \\
\hline & Upper $95 \% \mathrm{CL}$ & & & & ssf) & 1.54 & 4.17 & 0.040 & 0.004 & 3.21 & 0.29 & 15.48 & 0.009 & 0.012 \\
\hline \multirow[t]{4}{*}{ UTR } & Tinker Creek & Kennedys Pond & 1998 & $\mathrm{R}$ & whole fish & & & & & & & & & \\
\hline & Mean & & & & (rbsf, rfp, hs) & 0.12 & 3.51 & 0.001 & -0.001 & 3.40 & 0.00 & 0.67 & -0.006 & 0.000 \\
\hline & Max & & & & & 0.20 & 6.42 & 0.005 & 0.000 & 3.69 & 0.30 & 1.01 & -0.001 & 0.007 \\
\hline & Upper 95\% CL & & & & & 0.20 & 5.58 & 0.005 & 0.000 & 3.71 & 0.30 & 0.95 & -0.001 & 0.008 \\
\hline
\end{tabular}


WSRC-TR-2003-00149

Rev. 0

March 27, 2003

\begin{tabular}{|c|c|c|c|c|c|c|c|c|c|c|c|c|c|c|}
\hline IOU & Stream & Location & Year & 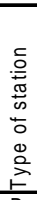 & 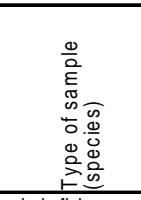 & 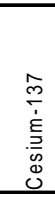 & 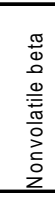 & 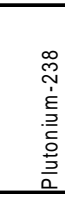 & 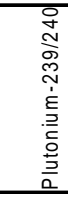 & 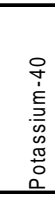 & 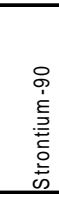 & 竞 & 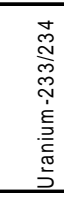 & 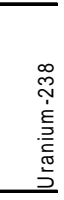 \\
\hline & $\begin{array}{l}\text { Upper Three Runs } \\
\text { Mean }\end{array}$ & Tyler Bridge & 1998 & $\mathrm{R}$ & whole fish & & 20 & 7000 & 0010 & & 016 & (277 & 0003 & 0.010 \\
\hline & $\operatorname{Max}$ & & & & (rbsf, cp, ss) & $\begin{array}{l}0.06 \\
0.08\end{array}$ & $\begin{array}{l}3.36 \\
3.83\end{array}$ & $\begin{array}{l}0.007 \\
0.010\end{array}$ & $\begin{array}{l}0.010 \\
0.010\end{array}$ & $\begin{array}{l}2.56 \\
3.59\end{array}$ & $\begin{array}{l}0.16 \\
0.20\end{array}$ & $\begin{array}{l}0.77 \\
1.29\end{array}$ & $\begin{array}{l}0.003 \\
0.010\end{array}$ & $\begin{array}{l}0.010 \\
0.020\end{array}$ \\
\hline & Upper 95\% CL & & & & & 0.08 & 3.67 & 0.013 & 0.010 & 3.51 & 0.20 & 1.34 & 0.010 & 0.021 \\
\hline & Upper Three Runs & Rd. C & 1998 & $\mathrm{PI}$ & whole fish & & & & & & & & & \\
\hline & Mean & & & & (bg, cp, Imb, & 0.14 & 2.92 & 0.004 & 0.023 & 2.96 & 0.15 & 1.10 & 0.010 & 0.010 \\
\hline & $\operatorname{Max}$ & & & & rbsf, sb, ss) & 0.31 & 3.53 & 0.040 & 0.010 & 3.84 & 0.25 & 1.83 & 0.020 & 0.020 \\
\hline & Upper 95\% CL & & & & & 0.22 & 3.29 & 0.018 & 0.049 & 3.40 & 0.21 & 1.43 & 0.014 & 0.014 \\
\hline & Upper Three Runs & Rd. A & 1998 & PI & whole fish & & & & & & & & & \\
\hline & Mean & & & & (bf, rbsf, ss) & 0.08 & 2.28 & 0.007 & 0.010 & 2.97 & 0.07 & 9.31 & 0.007 & 0.003 \\
\hline & $\operatorname{Max}$ & & & & & 0.11 & 2.58 & 0.020 & 0.020 & 3.05 & 0.09 & 11.30 & 0.010 & 0.010 \\
\hline & Upper 95\% CL & & & & & 0.12 & 2.58 & 0.020 & 0.021 & 3.10 & 0.11 & 11.78 & 0.013 & 0.010 \\
\hline \multirow[t]{44}{*}{ SR } & Savannah River & N. Augusta Rapids & 1999 & $R$ & whole fish & & & & & & & & & \\
\hline & Mean & & & & (bf, bg, rbsf, & 0.04 & 7.30 & 0.000 & 0.001 & 3.63 & 0.48 & 0.02 & 0.006 & 0.007 \\
\hline & $\operatorname{Max}$ & & & & resf, ss) & 0.11 & 8.22 & 0.006 & 0.017 & 4.41 & 0.73 & 0.08 & 0.023 & 0.024 \\
\hline & Upper $95 \% \mathrm{CL}$ & & & & & 0.09 & 8.20 & 0.004 & 0.006 & 4.05 & 0.66 & 0.06 & 0.016 & 0.015 \\
\hline & Savannah River & N. Augusta Rapids & 2001 & $R$ & fillet & & & & & & & & & \\
\hline & Mean & & & & (Imb, resf, ss) & 0.01 & 2.17 & 0.000 & 0.001 & 2.47 & 0.18 & 0.01 & 0.011 & 0.003 \\
\hline & $\operatorname{Max}$ & & & & & 0.01 & 2.77 & 0.002 & 0.002 & 3.00 & 0.28 & 0.02 & 0.015 & 0.008 \\
\hline & Upper $95 \%$ CL & & & & & 0.01 & 3.09 & 0.002 & 0.002 & 3.16 & 0.30 & 0.02 & 0.015 & 0.008 \\
\hline & Savannah River & N. Augusta Rapids & 2001 & $R$ & whole fish & & & & & & & & & \\
\hline & Mean & & & & (Imb, resf, ss) & 0.01 & 2.33 & 0.002 & 0.001 & 2.24 & 0.13 & -0.01 & 0.004 & 0.004 \\
\hline & $\operatorname{Max}$ & & & & & 0.02 & 3.16 & 0.004 & 0.002 & 2.39 & 0.15 & 0.00 & 0.007 & 0.007 \\
\hline & Upper $95 \%$ CL & & & & & 0.02 & 3.22 & 0.004 & 0.002 & 2.49 & 0.16 & 0.00 & 0.006 & 0.006 \\
\hline & Savannah River & below Lock \& Dam & 1999 & PI & whole fish & & & & & & & & & \\
\hline & Mean & & & & (resf, ss, bf) & 0.35 & 7.01 & -0.002 & -0.001 & 3.47 & 0.21 & -0.02 & 0.003 & 0.011 \\
\hline & $\operatorname{Max}$ & & & & & 0.75 & 8.12 & 0.004 & 0.002 & 4.23 & 0.49 & -0.02 & 0.007 & 0.025 \\
\hline & Upper $95 \% \mathrm{CL}$ & & & & & 0.73 & 8.09 & 0.006 & 0.001 & 4.15 & 0.41 & -0.02 & 0.007 & 0.021 \\
\hline & Savannah River & mouth of Upper Three & 1999 & PI & whole fish & & & & & & & & & \\
\hline & Mean & Runs & & & (bf, bg, rbsf, ss) & 0.04 & 7.10 & -0.001 & -0.003 & 3.29 & 0.37 & 0.01 & 0.009 & 0.009 \\
\hline & $\operatorname{Max}$ & & & & & 0.06 & 7.88 & 0.000 & -0.001 & 3.89 & 0.68 & 0.03 & 0.019 & 0.013 \\
\hline & Upper 95\% CL & & & & & 0.06 & 7.82 & 0.001 & 0.001 & 3.97 & 0.58 & 0.03 & 0.018 & 0.015 \\
\hline & Savannah River & near TNX & 2001 & $\mathrm{PI}$ & whole fish & & & & & & & & & \\
\hline & Mean & & & & (resf, ss, Imb) & 0.02 & 1.95 & 0.001 & 0.002 & 2.55 & 0.09 & 0.02 & 0.010 & 0.001 \\
\hline & $\operatorname{Max}$ & & & & & 0.04 & 2.37 & 0.003 & 0.004 & 2.69 & 0.17 & 0.03 & 0.019 & 0.003 \\
\hline & Upper $95 \% \mathrm{CL}$ & & & & & 0.04 & 2.45 & 0.003 & 0.005 & 2.70 & 0.19 & 0.04 & 0.021 & 0.004 \\
\hline & Savannah River & mouth of Four Mile & 1999 & $\mathrm{Pl}$ & whole fish & & & & & & & & & \\
\hline & Mean & Creek & & & (bf, rbsf, ss) & 0.07 & 8.05 & 0.000 & -0.001 & 3.09 & 1.10 & 1.40 & 0.008 & 0.002 \\
\hline & $\operatorname{Max}$ & & & & & 0.09 & 9.76 & 0.000 & 0.000 & 4.01 & 1.81 & 4.07 & 0.015 & 0.006 \\
\hline & Upper 95\% CL & & & & & 0.09 & 9.84 & 0.000 & 0.000 & 4.09 & 1.81 & 4.02 & 0.015 & 0.006 \\
\hline & Savannah River & mouth of Steel Creek & 1999 & $\mathrm{PI}$ & whole fish & & & & & & & & & \\
\hline & Mean & & & & (bf, resf, ss) & 0.39 & 5.94 & -0.001 & 0.001 & 3.33 & 0.46 & 1.58 & 0.009 & 0.008 \\
\hline & $\operatorname{Max}$ & & & & & 0.83 & 6.39 & -0.001 & 0.005 & 3.56 & 0.56 & 3.32 & 0.016 & 0.013 \\
\hline & Upper 95\% CL & & & & & 0.83 & 6.46 & -0.001 & 0.005 & 3.57 & 0.57 & 3.42 & 0.018 & 0.013 \\
\hline & Savannah River & mouth of Lower & 1999 & $\mathrm{PI}$ & whole fish & & & & & & & & & \\
\hline & Mean & Three Runs & & & (ss, bf, rbsf) & 0.37 & 7.54 & 0.000 & -0.001 & 2.82 & 0.38 & 0.53 & 0.007 & 0.003 \\
\hline & $\operatorname{Max}$ & & & & & 1.25 & 8.49 & 0.000 & 0.000 & 2.95 & 0.55 & 1.28 & 0.019 & 0.009 \\
\hline & Upper 95\% CL & & & & & 0.94 & 8.26 & 0.000 & 0.000 & 3.06 & 0.59 & 1.03 & 0.016 & 0.008 \\
\hline & Savannah River & Coleman Pond & 2001 & $\mathrm{PI}$ & whole fish & & & & & & & & & \\
\hline & Mean & (oxbow) & & & (bg, resf) & 0.04 & 2.32 & 0.00 & 0.00 & 2.49 & -0.01 & 0.00 & 0.01 & 0.00 \\
\hline & $\operatorname{Max}$ & & & & & 0.04 & 2.32 & 0.00 & 0.00 & 2.49 & -0.01 & 0.00 & 0.01 & 0.00 \\
\hline & Upper 95\% CL & & & & & & & & & & & & & \\
\hline & Savannah River & Highway 301 bridge & 1999 & $\mathrm{PI}$ & whole fish & & & & & & & & & \\
\hline & Mean & & & & (ss, bf, resf) & 0.06 & 6.09 & 0.001 & 0.000 & 2.80 & 0.34 & 0.11 & 0.003 & 0.001 \\
\hline & $\operatorname{Max}$ & & & & & 0.09 & 7.32 & 0.005 & 0.002 & 2.86 & 0.37 & 0.23 & 0.010 & 0.002 \\
\hline & Upper 95\% CL & & & & & 0.08 & 7.01 & 0.004 & 0.001 & 2.84 & 0.37 & 0.20 & 0.008 & 0.002 \\
\hline
\end{tabular}

* ss=spotted sucker, rbsf=redbreast sunfish, $c p=c h a i n$ pickerel, bhc=bluehead chub, fbh=flat bullhead, ccs=creek chubsucker, ybh=yellow bullhead, Ing=longnose gar, Imb=largemouth bass, resf=redear sunfish, gs=golden shiner, ssf=spotted sunfish, hs=hogsucker, rfp=redfin pickerel, sb=striped bass, bf=bowfin, $b g=b l u e g i l l$ 
WSRC-TR-2003-00149

Rev. 0

March 27, 2003

Table 10. Nonradioactive constituents (ug/kg) commonly above detection limits in fish from the Savannah River Site Integrator Operable Units. Station types include potentially influenced by SRS operations (PI) and reference (R)

\begin{tabular}{|c|c|c|c|c|c|c|c|c|c|c|c|c|c|c|c|c|c|c|}
\hline IOU & Stream & Location & 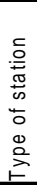 & Year & 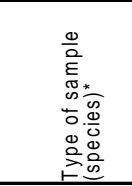 & 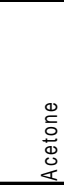 & 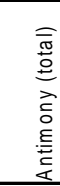 & 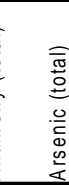 & 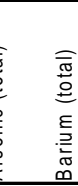 & 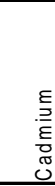 & 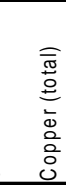 & 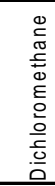 & 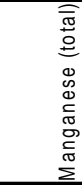 & 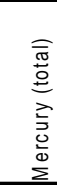 & 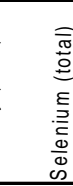 & 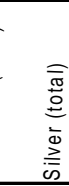 & $\begin{array}{l}\stackrel{0}{\Xi} \\
\stackrel{\Xi}{\Xi} \\
\stackrel{\circ}{\circ}\end{array}$ & 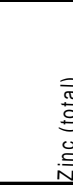 \\
\hline \multirow[t]{12}{*}{ FMC } & Four Mile Branch & Rd. A & $\mathrm{PI}$ & 1997 & whole fish & & & & & & & & & & & & & \\
\hline & Mean & & & & (ss, rbsf, cp) & 415 & 238 & 119 & 2368 & 214 & 679 & 70 & 14706 & 176 & 498 & 216 & 49 & 20140 \\
\hline & $\operatorname{Max}$ & & & & & 752 & 242 & 121 & 4640 & 594 & 1190 & 109 & 28600 & 415 & 553 & 604 & 85 & 35200 \\
\hline & Upper $95 \% \mathrm{CL}$ & & & & & 692 & 243 & 122 & 3704 & 422 & 1061 & 103 & 23898 & 333 & 563 & 429 & 74 & 28425 \\
\hline & Four Mile Branch & Rd. A & PI & 2001 & fillet & & & & & & & & & & & & & \\
\hline & Mean & & & & (rbsf, bhc, fbh) & 1115 & 228 & 132 & 6177 & 12 & 280 & 25 & 32886 & 56 & 544 & 215 & 2 & 40629 \\
\hline & $\operatorname{Max}$ & & & & & 1422 & 258 & 149 & 7595 & 14 & 418 & 32 & 33930 & 66 & 689 & 324 & 3 & 50373 \\
\hline & Upper 95\% CL & & & & & 1697 & 258 & 148 & 7631 & 14 & 432 & 31 & 34449 & 68 & 772 & 326 & 3 & 50716 \\
\hline & Four Mile Branch & Rd. A13.2 & PI & 2001 & whole fish & & & & & & & & & & & & & \\
\hline & Mean & & & & (ccs, rbsf, ybh) & 295 & 233 & 135 & 3202 & 29 & 255 & 24 & 11693 & 96 & 542 & 57 & 1 & 11214 \\
\hline & $\operatorname{Max}$ & & & & & 420 & 254 & 147 & 3628 & 37 & 488 & 32 & 14198 & 171 & 608 & 62 & 1 & 12580 \\
\hline & Upper $95 \% \mathrm{CL}$ & & & & & 494 & 258 & 150 & 3889 & 43 & 517 & 32 & 15142 & 170 & 621 & 63 & 1 & 12736 \\
\hline \multirow[t]{12}{*}{ LTR } & Lower Three Runs & Rd. B & $\mathrm{Pl}$ & 1997 & whole fish & & & & & & & & & & & & & \\
\hline & Mean & & & & (rbsf, Ing, fbh) & 271 & 243 & 231 & 3940 & 121 & 590 & 21 & 20550 & 450 & 426 & 121 & 21 & 20633 \\
\hline & $\operatorname{Max}$ & & & & & 608 & 250 & 297 & 4860 & 125 & 852 & 35 & 42100 & 859 & 543 & 125 & 30 & 24700 \\
\hline & Upper 95\% CL & & & & & 602 & 251 & 343 & 5283 & 125 & 857 & 38 & 41669 & 810 & 544 & 125 & 37 & 24633 \\
\hline & Lower Three Runs & Stinson Bridge & PI & 2001 & whole fish & & & & & & & & & & & & & \\
\hline & Mean & & & & (Imb, rbsf, ss) & 557 & 678 & 345 & 1648 & 308 & 272 & 46 & 7178 & 186 & 653 & 321 & 3 & 11997 \\
\hline & $\operatorname{Max}$ & & & & & 1482 & 916 & 459 & 3080 & 459 & 465 & 57 & 14590 & 324 & 963 & 459 & 3 & 20149 \\
\hline & Upper $95 \% \mathrm{CL}$ & & & & & 1470 & 1137 & 564 & 3158 & 599 & 528 & 57 & 14447 & 332 & 1033 & 587 & 3 & 20276 \\
\hline & Lower Three Runs & HW 125 & $\mathrm{Pl}$ & 2001 & fillet & & & & & & & & & & & & & \\
\hline & Mean & & & & (Imb, resf, ss) & 546 & 211 & 225 & 3117 & 12 & 58 & 33 & 100086 & 201 & 732 & 194 & 2 & 9344 \\
\hline & $\operatorname{Max}$ & & & & & 786 & 218 & 352 & 10675 & 12 & 145 & 39 & 388890 & 363 & 1047 & 222 & 3 & 12110 \\
\hline & Upper $95 \% \mathrm{CL}$ & & & & & 790 & 216 & 343 & 8060 & 12 & 116 & 43 & 288785 & 308 & 970 & 217 & 2 & 11530 \\
\hline \multirow[t]{12}{*}{ PB } & Pen Branch & Rd. B & $\mathrm{R}$ & 1997 & whole fish & & & & & & & & & & & & & \\
\hline & Mean & & & & & 516 & 238 & 119 & 5327 & 119 & 811 & 29 & 8440 & 315 & 513 & 119 & 17 & 17467 \\
\hline & $\operatorname{Max}$ & & & & & 608 & 246 & 123 & 7510 & 123 & 2080 & 38 & 14100 & 401 & 583 & 123 & 24 & 20200 \\
\hline & Upper 95\% CL & & & & & 609 & 249 & 124 & 8388 & 124 & 2056 & 38 & 14278 & 422 & 588 & 124 & 28 & 20579 \\
\hline & Pen Branch & Rd. A & $\mathrm{PI}$ & 1997 & whole fish & & & & & & & & & & & & & \\
\hline & Mean & & & & (ss, rbsf, lng) & 456 & 328 & 157 & 1466 & 119 & 264 & 46 & 7844 & 473 & 474 & 119 & 17 & 13682 \\
\hline & $\operatorname{Max}$ & & & & & 895 & 676 & 303 & 3460 & 125 & 450 & 72 & 16900 & 789 & 667 & 125 & 51 & 29200 \\
\hline & Upper 95\% CL & & & & & 792 & 519 & 237 & 2697 & 123 & 406 & 67 & 14121 & 802 & 584 & 123 & 39 & 22377 \\
\hline & Pen Branch & Rd A13.2 & $\mathrm{PI}$ & 2001 & whole fish & & & & & & & & & & & & & \\
\hline & Mean & & & & (ss, rbsf, Ing) & 102 & 193 & 112 & 1513 & 19 & 444 & 22 & 15373 & 181 & 731 & 47 & 1 & 11817 \\
\hline & $\operatorname{Max}$ & & & & & 402 & 241 & 140 & 4228 & 31 & 629 & 32 & 51417 & 269 & 833 & 59 & 1 & 19001 \\
\hline & Upper 95\% CL & & & & & 298 & 236 & 136 & 3434 & 27 & 673 & 32 & 39236 & 277 & 847 & 57 & 1 & 18800 \\
\hline \multirow[t]{16}{*}{ SC } & Meyers Branch & Rd. 9 & $\mathrm{R}$ & 1996 & whole fish & & & & & & & & & & & & & \\
\hline & Mean & & & & (rbsf, bhc, ssf) & 336 & $\star \star \star *$ & $7317^{\star \star}$ & $6750^{\star \star}$ & 122 & $\star \star \star$ & 21 & 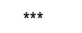 & 266 & $7317^{\star *}$ & $608^{* *}$ & 20 & 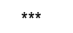 \\
\hline & $\operatorname{Max}$ & & & & & 461 & $\star \star \star$ & $7450^{\star \star}$ & $9120^{\star \star}$ & 124 & $\star \star *$ & 26 & $\star \star \star ~$ & 324 & $7450^{\star \star}$ & $620^{\star *}$ & 30 & $\star \star * *$ \\
\hline & Upper $95 \% \mathrm{CL}$ & & & & & 467 & $* * *$ & $7459^{\star *}$ & $9321^{\star *}$ & 124 & $* * *$ & 26 & *** & 371 & $7459^{\star \star}$ & $620^{* *}$ & 37 & $\star \star *$ \\
\hline & Steel Creek & Rd. B & PI & 1996 & whole fish & & & & & & & & & & & & & \\
\hline & Mean & & & & (rbsf, fbh, gs) & 374 & $* * *$ & $7117^{\star *}$ & $13270^{\star *}$ & 119 & $* * *$ & 13 & $* * *$ & 109 & $7117^{\star \star}$ & $593^{* *}$ & 23 & $\star \star *$ \\
\hline & $\operatorname{Max}$ & & & & & 412 & $\star \star *$ & $7200^{\star *}$ & $17500^{\star *}$ & 120 & $\star * *$ & 14 & $* * *$ & 156 & $7200^{\star *}$ & $600^{* *}$ & 39 & $\star * *$ \\
\hline & Upper 95\% CL & & & & & 428 & $\star \star \star$ & $7234^{\star *}$ & $21076^{\text {** }}$ & 120 & $\star \star \star ~$ & 14 & $* \star *$ & 167 & $7234^{\star *}$ & $602^{\star \star}$ & 39 & $* \star *$ \\
\hline & Steel Creek & Rd. A & PI & 1996 & whole fish & & & & & & & & & & & & & \\
\hline & Mean & & & & (Imb, rbsf, ss) & 197 & $* \star *$ & 7250 ** & $2697^{\star *}$ & 121 & $* * *$ & 11 & $* \star *$ & 358 & $7250^{\star *}$ & $603^{* *}$ & 29 & $* \star *$ \\
\hline & $\operatorname{Max}$ & & & & & 307 & $* * *$ & $7350^{* *}$ & $4020^{* *}$ & 123 & $* * *$ & 12 & $* * *$ & 693 & $7350^{* *}$ & $615^{\star \star}$ & 56 & $* * *$ \\
\hline & Upper 95\% CL & & & & & 309 & 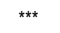 & $7400^{\star *}$ & $4185^{\star \star}$ & 123 & 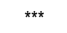 & 12 & $\star \star \star ~$ & 687 & $7400^{* *}$ & $618^{\star \star}$ & 57 & $\star * \star$ \\
\hline & Steel Creek & Floodplain swamp & $\mathrm{Pl}$ & 1997 & whole fish & & & & & & & & & & & & & \\
\hline & Mean & & & & (ybh, resf, bf, & 526 & 240 & 120 & 5023 & 120 & 391 & 47 & 8494 & 314 & 548 & 120 & 28 & 15973 \\
\hline & $\operatorname{Max}$ & & & & ss, Imb, rbsf, & 791 & 250 & 125 & 16900 & 125 & 711 & 86 & 23400 & 765 & 798 & 125 & 57 & 33300 \\
\hline & Upper 95\% CL & & & & ssf) & 747 & 248 & 124 & 11505 & 124 & 639 & 72 & 18132 & 588 & 664 & 124 & 46 & 28504 \\
\hline \multirow[t]{4}{*}{ UTR } & Tinker Creek & Kennedys Pond & $\mathrm{R}$ & 1998 & whole fish & & & & & & & & & & & & & \\
\hline & Mean & & & & (rbsf, rfp, hs) & 371 & 232 & 116 & 2846 & 116 & 579 & 48 & 11845 & 102 & 479 & 116 & 38 & 30583 \\
\hline & $\operatorname{Max}$ & & & & & 573 & 235 & 118 & 4250 & 118 & 743 & 55 & 29200 & 273 & 514 & 118 & 66 & 52400 \\
\hline & Upper $95 \% \mathrm{CL}$ & & & & & 571 & 235 & 118 & 5520 & 118 & 752 & 62 & 29174 & 251 & 527 & 118 & 65 & 55224 \\
\hline
\end{tabular}


Rev. 0

March 27, 2003

\begin{tabular}{|c|c|c|c|c|c|c|c|c|c|c|c|c|c|c|c|c|c|c|}
\hline IOU & Stream & Location & 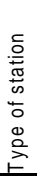 & Year & 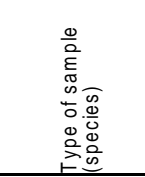 & 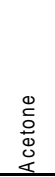 & 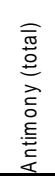 & 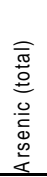 & 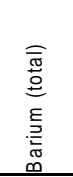 & 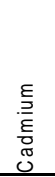 & $\begin{array}{l}\text { ত̃ } \\
\stackrel{0}{0} \\
\frac{0}{0} \\
\frac{0}{0} \\
0 \\
0\end{array}$ & 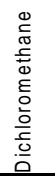 & 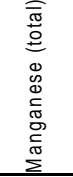 & 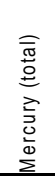 & 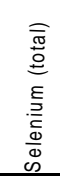 & 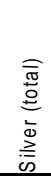 & $\begin{array}{l}\stackrel{0}{\Xi} \\
\text { อ } \\
\stackrel{0}{\circ} \\
\end{array}$ & 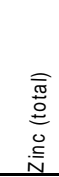 \\
\hline & Upper Three Runs & Tyler Bridge & $\mathrm{R}$ & 1998 & whole fish & & & & & & & & & & & & & \\
\hline & Mean & & & & (rbsf, cp, ss) & 381 & 686 & 217 & 10433 & 217 & 679 & 221 & 4600 & 163 & 844 & 217 & 25 & 26200 \\
\hline & $\operatorname{Max}$ & & & & & 472 & 1200 & 221 & 19900 & 221 & 945 & 307 & 6020 & 240 & 1000 & 221 & 25 & 44100 \\
\hline & Upper 95\% CL & & & & & 472 & 1190 & 222 & 19910 & 222 & 965 & 307 & 7180 & 245 & 1023 & 222 & 25 & 45566 \\
\hline & Upper Three Runs & Rd. C & PI & 1998 & whole fish & & & & & & & & & & & & & \\
\hline & Mean & & & & (bg, cp, Imb, & 1281 & 591 & 284 & 2823 & 236 & 534 & 335 & 5678 & 92 & 589 & 236 & 62 & 23050 \\
\hline & $\operatorname{Max}$ & & & & rbsf, sb, ss) & 5300 & 1210 & 538 & 5610 & 250 & 882 & 563 & 10400 & 133 & 984 & 250 & 248 & 50800 \\
\hline & Upper 95\% CL & & & & & 2887 & 834 & 384 & 4089 & 246 & 752 & 463 & 8389 & 122 & 817 & 246 & 135 & 34885 \\
\hline & Upper Three Runs & Rd. A & $\mathrm{PI}$ & 1998 & whole fish & & & & & & & & & & & & & \\
\hline & Mean & & & & (bf, rbsf, ss) & 550 & 452 & 226 & 2010 & 226 & 1354 & 444 & 5867 & 83 & 771 & 226 & 25 & 11340 \\
\hline & $\operatorname{Max}$ & & & & & 895 & 495 & 248 & 2710 & 248 & 2300 & 674 & 8970 & 112 & 811 & 248 & 25 & 13800 \\
\hline & Upper 95\% CL & & & & & 890 & 495 & 248 & 2858 & 248 & 2406 & 670 & 9675 & 113 & 817 & 248 & 25 & 15871 \\
\hline \multirow[t]{44}{*}{ SR } & Savannah River & N. Augusta Rapids & $\mathrm{R}$ & 1999 & whole fish & & & & & & & & & & & & & \\
\hline & Mean & & & & (bf, bg, rbsf, & 914 & 367 & 528 & 3652 & 70 & 688 & 85 & 33820 & 56 & 957 & 146 & 22 & 14732 \\
\hline & $\operatorname{Max}$ & & & & resf, ss) & 2490 & 459 & 841 & 3930 & 227 & 1280 & 209 & 66600 & 99 & 1020 & 229 & 80 & 19500 \\
\hline & Upper 95\% CL & & & & & 1724 & 476 & 723 & 3973 & 147 & 1018 & 150 & 51105 & 82 & 1001 & 216 & 50 & 18976 \\
\hline & Savannah River & N. Augusta Rapids & $\mathrm{R}$ & 2001 & fillet & & & & & & & & & & & & & \\
\hline & Mean & & & & (Imb, resf, ss) & 487 & 880 & 545 & 1168 & 440 & 313 & 22 & 11009 & 64 & 438 & 440 & 3 & 9379 \\
\hline & $\operatorname{Max}$ & & & & & 645 & 997 & 686 & 1691 & 499 & 653 & 28 & 27405 & 130 & 493 & 499 & 5 & 13703 \\
\hline & Upper 95\% CL & & & & & 642 & 1027 & 686 & 1857 & 513 & 647 & 28 & 27359 & 131 & 544 & 513 & 6 & 14569 \\
\hline & Savannah River & N. Augusta Rapids & $\mathrm{R}$ & 2001 & whole fish & & & & & & & & & & & & & \\
\hline & Mean & & & & (Imb, resf, ss) & 442 & 199 & 229 & 1967 & 11 & 542 & 16 & 11706 & 40 & 424 & 77 & 2 & 12097 \\
\hline & $\operatorname{Max}$ & & & & & 799 & 223 & 345 & 5507 & 12 & 1185 & 26 & 20932 & 67 & 509 & 105 & 3 & 14955 \\
\hline & Upper 95\% CL & & & & & 677 & 217 & 351 & 4286 & 12 & 962 & 23 & 18608 & 65 & 509 & 106 & 3 & 14530 \\
\hline & Savannah River & below Lock \& Dam & $\mathrm{PI}$ & 1999 & whole fish & & & & & & & & & & & & & \\
\hline & Mean & & & & (resf, ss, bf) & 134 & 480 & 571 & 4823 & 141 & 2456 & 45 & 17100 & 297 & 1512 & 321 & 5 & 19075 \\
\hline & $\operatorname{Max}$ & & & & & 180 & 500 & 666 & 6500 & 250 & 7300 & 63 & 38000 & 618 & 2850 & 712 & 5 & 23600 \\
\hline & Upper 95\% CL & & & & & 183 & 494 & 634 & 6483 & 256 & 5661 & 57 & 31077 & 552 & 2402 & 584 & 5 & 23758 \\
\hline & Savannah River & mouth of Upper Threr & $\mathrm{PI}$ & 1999 & whole fish & & & & & & & & & & & & & \\
\hline & Mean & Runs & & & (bf, bg, rbsf, ss) & 180 & 411 & 591 & 5158 & 81 & 1132 & 46 & 41990 & 166 & 992 & 201 & 6 & 22175 \\
\hline & $\operatorname{Max}$ & & & & & 347 & 495 & 713 & 7830 & 245 & 2550 & 112 & 76200 & 268 & 1130 & 248 & 10 & 36200 \\
\hline & Upper 95\% CL & & & & & 294 & 552 & 696 & 7782 & 188 & 2122 & 89 & 73697 & 278 & 1108 & 288 & 9 & 32444 \\
\hline & Savannah River & near TNX & PI & 2001 & whole fish & & & & & & & & & & & & & \\
\hline & Mean & & & & (resf, ss, Imb) & 467 & 197 & 210 & 2911 & 11 & 221 & 30 & 33259 & 62 & 667 & 198 & 2 & 13694 \\
\hline & $\operatorname{Max}$ & & & & & 976 & 213 & 397 & 6603 & 12 & 363 & 44 & 86391 & 131 & 804 & 235 & 3 & 23855 \\
\hline & Upper 95\% CL & & & & & 966 & 212 & 393 & 6606 & 12 & 423 & 43 & 85799 & 130 & 812 & 235 & 3 & 23993 \\
\hline & Savannah River & mouth of Four Mile & $\mathrm{PI}$ & 1999 & whole fish & & & & & & & & & & & & & \\
\hline & Mean & Creek & & & (bf, rbsf, ss) & 115 & 392 & 553 & 3166 & 109 & 437 & 54 & 29853 & 146 & 975 & 239 & 5 & 15027 \\
\hline & $\operatorname{Max}$ & & & & & 129 & 495 & 586 & 5820 & 248 & 746 & 103 & 56900 & 222 & 1150 & 248 & 6 & 22200 \\
\hline & Upper 95\% CL & & & & & 136 & 560 & 587 & 6218 & 247 & 741 & 102 & 61129 & 235 & 1196 & 250 & 6 & 24386 \\
\hline & Savannah River & mouth of Steel Creek & PI & 1999 & whole fish & & & & & & & & & & & & & \\
\hline & Mean & & & & (bf, resf, ss) & 135 & 476 & 555 & 3640 & 204 & 516 & 53 & 16353 & 516 & 1000 & 238 & 5 & 16767 \\
\hline & $\operatorname{Max}$ & & & & & 223 & 485 & 758 & 5500 & 238 & 778 & 78 & 34400 & 1250 & 1080 & 243 & 5 & 24000 \\
\hline & Upper 95\% CL & & & & & 223 & 486 & 760 & 5947 & 267 & 814 & 80 & 34315 & 1236 & 1120 & 243 & 5 & 24420 \\
\hline & Savannah River & mouth of Lower & PI & 1999 & whole fish & & & & & & & & & & & & & \\
\hline & Mean & Three Runs & & & (ss, bf, rbsf) & 131 & 332 & 653 & 3870 & 33 & 1286 & 102 & 33623 & 290 & 1071 & 190 & 11 & 18850 \\
\hline & $\operatorname{Max}$ & & & & & 156 & 495 & 873 & 6580 & 47 & 2910 & 282 & 93400 & 474 & 1340 & 248 & 18 & 28000 \\
\hline & Upper 95\% CL & & & & & 148 & 499 & 811 & 5782 & 44 & 2393 & 220 & 74003 & 489 & 1252 & 286 & 19 & 25530 \\
\hline & Savannah River & Coleman Pond & $\mathrm{PI}$ & 2001 & whole fish & & & & & & & & & & & & & \\
\hline & Mean & (oxbow) & & & (bg, resf) & 499 & 223 & 129 & 5768 & 12 & 220 & 27 & 98397 & 5 & 806 & 300 & 1 & 29754 \\
\hline & $\operatorname{Max}$ & & & & & 499 & 223 & 129 & 5768 & 12 & 220 & 27 & 98397 & 5 & 806 & 300 & 1 & 29754 \\
\hline & Upper 95\% CL & & & & & $\star \star \star \star *$ & 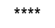 & $\star \star \star \star *$ & 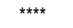 & $\star \star \star \star *$ & $\star \star \star \star *$ & $* * * *$ & 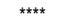 & 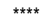 & $* \star \star *$ & $\star \star \star \star *$ & $* \star \star *$ & $\star * \star \star *$ \\
\hline & Savannah River & Highway 301 bridge & $\mathrm{PI}$ & 1999 & whole fish & & & & & & & & & & & & & \\
\hline & Mean & & & & (ss, bf, resf) & 227 & 224 & 372 & 2390 & 163 & 664 & 80 & 11887 & 314 & 930 & 102 & 5 & 20167 \\
\hline & $\operatorname{Max}$ & & & & & 423 & 263 & 426 & 2690 & 240 & 1200 & 103 & 18600 & 543 & 1070 & 135 & 5 & 24600 \\
\hline & Upper 95\% CL & & & & & 419 & 274 & 426 & 2968 & 303 & 1190 & 104 & 18701 & 538 & 1068 & 135 & 5 & 25578 \\
\hline
\end{tabular}


WSRC-TR-2003-00149

Rev. 0

March 27, 2003

Mercury is an important nonradioactive constituent in fish tissues since it sometimes reaches concentrations high enough to result in fish consumption advisories. Mercury concentrations in fish from Upper Three Runs and Tinker creek were generally lower than in fish from other streams on the SRS (Table 10).

\section{HDMI and MHSP}

In 1997/1998, the HDMI was calculated for Upper Three Runs at locations near Tyler Bridge Road and Road C. It was also calculated at locations in four Upper Three Runs tributaries including Crouch Branch (Road 4), McQueen Branch (Z Area), Tims Branch (Road 2), and Mill Creek (Telephone Cable Road). The sample sites in Upper Three Runs near Tyler Bridge Road and in Mill Creek were reference sites; the other sites were potentially impacted. The average HDMI was 28.4 at Upper Three Runs near Road C and 23.2 at McQueen Branch. Neither value differed significantly from the average HDMI at the control sites (31.4, Table 11), although the HDMI at McQueen Branch was marginal. Average HDMIs at Crouch Branch (12.8) and Tims Branch (19.2) were significantly lower than at the control sites.

The HDMI was again calculated for the Upper Three Runs IOU during 2000. Sample locations included UpperThree Runs near Road 8-1, Upper Three Runs near Road C, Crouch Branch near Road 4, McQueen Branch near Road F, Tims Branch near Road 2, and Mill Creek near the Telephone Cable Road (Table 11). The average HDMI values for Upper Three Runs near Road 8-1 and Mill Creek, both of which were reference sites, were 34.8 and 38.0 , respectively. These values were comparable to the HDMI values at the other reference sites sampled during 2000 (Table 11). The average HDMI at Upper Three Runs near Road C, which was located in a potentially disturbed area, was 32.8. This value was also relatively high and did not differ significantly from the control site values. However, HDMI values at Crouch Branch (averaging 18.0), Tims Branch (averaging 22.5), and McQueen Branch (averaging 15.2), were significantly lower than control site HDMIs.

Although significantly depressed during both 1997/1998 and 2000, the HDMI in Crouch Branch improved from 12.8 to 18.0 (Table 11). This improvement was paralleled by an improvement in the IBI, which reached normal levels by 2000.

Biological degradation in Crouch Branch was probably related to elevated copper concentrations in discharge from the H-02 outfall located upstream from Road 4. Reductions in copper concentrations in the H-02 discharge (Specht 1999) contributed to improvements in Crouch Branch, although the relatively low HDMI observed in 2000 indicated that recovery was not complete.

Unlike Crouch Branch, the HDMI in Tims Branch exhibited relatively little change between 1997/1998 (19.2) and 2000 (22.5) (Table 11). It is likely that the periodic release of anoxic water from upstream beaver ponds was responsible for the depressed HDMI in Tims Branch. These beaver ponds were in the old bed of Steeds Pond, which was located just upstream of the sample area. At the time of sampling, the water flowing out of the old pond bed appeared to contain an iron hydroxide floc, which suggests that the beaver ponds were probably producing anoxic conditions that resulted in the release of ferrous iron from the pond sediments. A water sample collected just downstream from the old Steeds Pond dam indicated that total iron and aluminum were high (3620 and $1620 \mu \mathrm{g} / \mathrm{l}$, respectively), but that none of the other metals that were measured, including 
WSRC-TR-2003-00149

Rev. 0

March 27, 2003

Table 11. HDMI values from sites located in Upper Three Runs (UTR), Fourmile Branch (FMB), Pen Branch (PB), and Steel Creek (SC). There were five replicates at each site. Type refers to reference (R) or possibly impacted (PI). The highest possible HDMI scores were 35 in 1997/1998 and 40 in 2000 (see Methods and Materials). The column titled "Avg. as \% of max." represents the average HDMI as a percentage of the maximum possible HDMI for each time period.

\begin{tabular}{|c|c|c|c|c|c|c|c|c|}
\hline IOU & Stream & Location & Type & Avg. & $\begin{array}{l}\text { Avg. as } \\
\% \text { max. }\end{array}$ & $\begin{array}{l}\text { St. } \\
\text { err. }\end{array}$ & Max. & Min. \\
\hline & \multicolumn{8}{|c|}{1997 and 1998} \\
\hline \multirow[t]{6}{*}{$\begin{array}{l}\text { UTR } \\
\end{array}$} & Upper Three Runs & Tyler Bridge Rd & $\mathrm{R}$ & 28.4 & 81 & 3.1 & 36 & 18 \\
\hline & Upper Three Runs & $\underline{\mathrm{Rd} C}$ & $\mathrm{PI}$ & 28.4 & 81 & 2.3 & 36 & 22 \\
\hline & Crouch Branch & $\underline{\mathrm{Rd} 4}$ & $\mathrm{PI}$ & 12.8 & 37 & 0.8 & 16 & 12 \\
\hline & McQueen Branch & Z Area & $\mathrm{PI}$ & 23.2 & 66 & 3.6 & 30 & 10 \\
\hline & Tims Branch & $\mathrm{Rd} 2$ & $\mathrm{PI}$ & 19.2 & 55 & 0.5 & 20 & 18 \\
\hline & Mill Creek & Telephone cable Rd & $\mathrm{R}$ & 33.6 & 96 & 1.0 & 36 & 32 \\
\hline \multirow[t]{4}{*}{ FMB } & Fourmile Branch & $\mathrm{Rd} F$ & $\mathrm{R}$ & 13.6 & 39 & 1.6 & 20 & 12 \\
\hline & Fourmile Branch & $\mathrm{Rd} C$ & $\mathrm{PI}$ & 18.4 & 53 & 1.7 & 22 & 12 \\
\hline & Fourmile Branch & $\mathrm{Rd} A-7$ & $\mathrm{PI}$ & 20.4 & 58 & 2.1 & 28 & 16 \\
\hline & Fourmile Branch & $\mathrm{Rd} A$ & $\mathrm{PI}$ & 31.2 & 89 & 1.7 & 36 & 26 \\
\hline \multirow[t]{4}{*}{ PB } & Pen Branch & $\mathrm{Rd} C$ & $\mathrm{PI}$ & 32.0 & 91 & 1.9 & 36 & 26 \\
\hline & Pen Branch & $\mathrm{Rd} B$ & $\mathrm{PI}$ & 32.4 & 93 & 1.8 & 36 & 28 \\
\hline & Pen Branch & $\mathrm{Rd} A$ & $\mathrm{R}$ & 24.8 & 71 & 3.0 & 32 & 14 \\
\hline & Indian Grave & $\underline{\mathrm{K} \text { Cooling Tower }}$ & $\mathrm{PI}$ & 28.0 & 80 & 2.8 & 32 & 18 \\
\hline \multirow[t]{3}{*}{ SC } & Steel Creek & $\mathrm{Rd} \mathrm{C}$ & $\mathrm{PI}$ & 22.4 & 64 & 3.3 & 32 & 12 \\
\hline & Meyers Branch & Old Dunbarton Rd & $\mathrm{R}$ & 30.8 & 88 & 1.7 & 36 & 26 \\
\hline & \multicolumn{8}{|c|}{2000} \\
\hline \multirow[t]{6}{*}{ UTR } & Upper Three Runs & $\mathrm{Rd} 8-1$ & $\mathrm{R}$ & 34.8 & 87 & 2.1 & 40 & 26 \\
\hline & Upper Three Runs & $\underline{\mathrm{Rd} C}$ & $\mathrm{PI}$ & 32.8 & 82 & 1.9 & 38 & 28 \\
\hline & Crouch Branch & $\underline{\mathrm{Rd} 4}$ & $\mathrm{PI}$ & 18.0 & 45 & 2.0 & 24 & 12 \\
\hline & McQueen Branch & $\mathrm{Rd} F$ & $\mathrm{PI}$ & 15.2 & 38 & 1.7 & 22 & 12 \\
\hline & Tims Branch & $\mathrm{Rd} 2$ & $\mathrm{PI}$ & 22.5 & 56 & 3.4 & 28 & 14 \\
\hline & Mill Creek & Telephone cable Rd & $\mathrm{R}$ & 38.0 & 95 & 1.1 & 40 & 34 \\
\hline \multirow[t]{4}{*}{ FMB } & Fourmile Branch & $\mathrm{Rd} F$ & $\mathrm{R}$ & 17.2 & 43 & 1.6 & 22 & 14 \\
\hline & Fourmile Branch & $\mathrm{Rd} C$ & PI & 30.0 & 75 & 3.3 & 38 & 20 \\
\hline & Fourmile Branch & $\mathrm{Rd} A-6$ & $\mathrm{PI}$ & 30.0 & 75 & 1.8 & 36 & 26 \\
\hline & Fourmile Branch & $\mathrm{Rd} A$ & PI & 32.0 & 80 & 1.7 & 36 & 28 \\
\hline \multirow[t]{4}{*}{ PB } & Pen Branch & $\mathrm{Rd} C$ & $\mathrm{PI}$ & 35.2 & 88 & 2.1 & 40 & 28 \\
\hline & Pen Branch & $\mathrm{Rd} B$ & PI & 38.8 & 97 & 0.5 & 40 & 38 \\
\hline & Pen Branch & $\mathrm{Rd} A$ & $\mathrm{R}$ & 34.8 & 87 & 1.0 & 38 & 32 \\
\hline & Indian Grave & $\underline{\text { K Cooling Tower }}$ & $\mathrm{PI}$ & 33.2 & 83 & 1.9 & 38 & 28 \\
\hline \multirow[t]{2}{*}{ SC } & Steel Creek & $\mathrm{Rd} C$ & $\mathrm{PI}$ & 31.6 & 79 & 1.5 & 36 & 28 \\
\hline & Meyers Branch & Old Dunbarton Rd & $\mathrm{R}$ & 33.2 & 83 & 1.4 & 38 & 30 \\
\hline \multirow[t]{2}{*}{ LTR } & Lower Three Runs & Donora Station & $\mathrm{PI}$ & 28.0 & 70 & 1.3 & 32 & 26 \\
\hline & Lower Three Runs & Stinson Bridge & $\mathrm{PI}$ & 30.4 & 76 & 1.5 & 36 & 28 \\
\hline
\end{tabular}


WSRC-TR-2003-00149

Rev. 0

March 27, 2003

dissolved iron, exceeded EPA water quality criteria (discussed more fully in Paller and Specht 2001).

The HBMI from McQueen Branch exhibited a decrease from 1997/1998 (19.2) to 2000 (15.2) (Table 11). This change was probably related to the relocation of the sampling site from Z Area to Road F in 2000 because of flooding by beaver dams near Z Area. The Road $F$ sampling location was scoured by runoff during construction of the Defense Waste Processing Facility (DWPF) in the 1980's, was deeply channelized, and had poorer habitat than the sampling location near Z Area. It is also possible that discharges from NPDES outfalls upstream from the sampling area contributed to the low HDMI in McQueen Branch near Road F.

In 2003 the MHSP was used to collect macroinvertbrates from streams on the SRS. This represented a departure from earlier macroinvertebrate sampling programs that utilized Hester-Dendy artificial substrates to collect macroinvertebrates. The bioclassification scores generated from the MHSP data and the HDMI scores generated from the Hester-Dendy data are not directly comparable because of differences in sampling methods, metrics, and scoring scales; however, both are indicators of stream ecological health. MHSP sampling locations in the Upper Three Runs watershed included Upper Three Runs at Tyler Bridge Road, Upper Three Runs at Road C, Tims Branch at Road 2, Crouch Branch at Road 4, Crouch Branch mouth, Tinker Creek at Kennedy's Pond, Tinker Creek at Tyler Bridge Road, Mill Creek at Monroe Owens Road, Mill Creek at telephone cable right-of-way, and McQueen Branch near Z Area. Tims Branch near Road 2 and Crouch Branch near Road 4 received MHSP bioclassification scores of Poor (Table 12). The Tims Branch location appeared to be channelized, and the stream bottom contained large amounts of iron floc (iron hydroxide). Crouch Branch at Road 4 is just downstream from the H-02 NPDES outfall, which discharges noncontact cooling water with elevated copper levels. Steps are being taken to reduce copper concentrations at the outfall, but the stream is clearly impacted as indicated by its low MHSP bioclassification score. Both Tims Branch and Crouch Branch at Road 4 received low Habitat Scores (81-95) reflecting relatively poor habitat for macroinvertebrates at both sites (Table 12).

With the exception of Tims Branch and Crouch Branch at Road 4, all of the sampling sites in the Upper Three Runs drainage were rated fair or higher using the MHSP scoring system. However, none, including the undisturbed sites at Tyler Bridge Road, Tinker Creek, and Mill Creek, received more than a Good- score using the MHSP scoring system (Table 12). Based on studies conducted by Dr. John Morse at Clemson University and others, Upper Three Runs is an outstanding resource. Ratings of Fair to Good- for this stream and other undisturbed streams in the Upper Three Runs watershed suggest that the SCDHEC bioclassification rating system may underestimate benthic community quality in some cases. Deep water in Upper Three Runs and Tinker Creek at Tyler Bridge Road may have reduced sampling efficiency, thus lowering the scores for these streams, although scores were also relatively low for other undisturbed sites that were easier to sample. 
Table 12. MHSP water quality rating scores and habitat scores for streams in the Upper Three Runs (UTR), Fourmile Branch (FMB), Pen Branch (PB), Steel Creek (SC) and Lower Three Runs (LTR) Integrator Operable Units (IOUs).

\begin{tabular}{|c|c|c|c|c|c|c|c|}
\hline IOU & Stream & Location & Score & Rating & $\begin{array}{l}\text { Adjusted } \\
\text { Score }\end{array}$ & $\begin{array}{c}\text { Adjusted } \\
\text { Rating }\end{array}$ & $\begin{array}{l}\text { Habitat } \\
\text { Score }\end{array}$ \\
\hline \multirow[t]{10}{*}{ UTR } & Upper Three Runs & Tyler Bridge Rd & 3.2 & Good-Fair & 4.0 & Good & 168 \\
\hline & Upper Three Runs & $\mathrm{Rd} C$ & 4.0 & Good & 4.5 & Good+ & 136 \\
\hline & Tims Branch & $\mathrm{Rd} 2$ & 1.0 & Poor & 1 & Poor & 95 \\
\hline & Crouch Branch & $\mathrm{Rd} 4$ & 1.2 & Poor & 1.2 & Poor & 81 \\
\hline & Crouch Branch & Near UTR & 2.0 & Fair & 2.5 & Fair+ & 108 \\
\hline & Tinker Creek & Kennedy Pond Rd & 2.7 & Good-Fair & 3.5 & Good-Fair+ & 150 \\
\hline & Tinker Creek & Tyler Bridge Rd & 3.5 & Good - & 4.5 & Good+ & 146 \\
\hline & Mill Creek & Monroe Owens Rd & 2.5 & Fair + & 3.0 & Good-Fair & 171 \\
\hline & Mill Creek & Telephone Cable Rd & 3.2 & Good-Fair & 4.5 & Good+ & 168 \\
\hline & McQueen Branch & Z Area & 3.5 & Good - & 5.0 & Excellent & 149 \\
\hline \multirow[t]{3}{*}{ FMB } & Fourmile Branch & $\mathrm{Rd} 4$ & 1.5 & Fair - & 2.0 & Fair & 126 \\
\hline & Fourmile Branch & $\mathrm{Rd} A-7$ & 2.5 & Fair + & 3.3 & Good-Fair & 152 \\
\hline & Fourmile Branch & $\mathrm{Rd} A$ & 2.5 & Fair + & 3.8 & Good & 167 \\
\hline \multirow[t]{4}{*}{ PB } & Indian Grave Branch & K Cooling Tower & 2.2 & Fair & 3.0 & Good-Fair & 144 \\
\hline & Pen Branch & $\mathrm{Rd} \mathrm{C}$ & 3.5 & Good - & 4.8 & Excellent & 155 \\
\hline & Pen Branch & $\mathrm{Rd} B$ & 2.5 & Fair + & 3.0 & Good-Fair & 160 \\
\hline & Pen Branch & $\operatorname{Rd} A$ & 2.5 & Fair + & 3.0 & Good-Fair & 158 \\
\hline \multirow[t]{3}{*}{ SC } & Steel Creek & $\mathrm{Rd} \mathrm{C}$ & 2.5 & Fair + & 3.3 & Good-Fair & 168 \\
\hline & Meyers Branch & Old Dunbarton Rd & 1.7 & Fair & 2.1 & Fair & 140 \\
\hline & Meyers Branch & Rd B-6.2 & 1.0 & Poor & 1.0 & Poor & 76 \\
\hline \multirow[t]{2}{*}{ LTR } & Lower Three Runs & Donora Station & 2.2 & Fair & 2.5 & Fair+ & 165 \\
\hline & Lower Three Runs & Patterson Mill & 2.2 & Fair & 2.7 & Good-Fair & 142 \\
\hline
\end{tabular}


WSRC-TR-2003-00149

Rev. 0

March 27, 2003

For this study, an effort was made to adjust the MHSP bioclassification scores for stream size to obtain ratings in better agreement with previously collected data and the history of the streams under study (see Methods and Materials for details concerning theadjustment). This adjustment increased the bioclassification score for most streams, except those that were rated Poor (Table 12). McQueen Branch received an Excellent rating, and most other locations received ratings of Good/Fair or Good. These ratings were in good agreement with the habitat scores, which (excluding Tims Branch and Crouch Branch) generally ranged from about 150 to 170 (out of a possible 200) indicating good habitat for low gradient streams. In contrast, Tims Branch and Crouch Branch received habitat scores of 81-108. Tims Branch had poor substrate quality, heavy sediment deposition, channelization, and reduced vegetation protection. Crouch Branch had poor substrate quality, lack of pool habitat, heavy sediment deposition, eroded unstable banks, and reduced vegetation protection. Both Tims Branch and Crouch Branch at Road 4 continued to receive bioclassification ratings of Poor based on benthic macroinvertebrate community quality, even after adjustment for stream size.

\section{Summary for Upper Three Runs IOU}

Although there was evidence of contamination in Upper Three Runs (moderately elevated levels of tritium in fish tissues), the combined results from IBI, HAI, HDMI, and MHSP analyses indicated little ecological damage in this stream and in its tributary, Mill Creek. However, ecological degradation was evident in Crouch Branch and Tims Branch, two small tributaries of Upper Three Runs. This was most evident in the macroinvertebrate based assessment protocols (HDMI values in 1997/1998 and 2000 and the MHSP bioclassification score in 2003. Degradation in both streams was at least partly habitat related as indicated by low habitat scores (Table 12). In the case of Crouch Branch, high copper levels in an NPDES discharge were likely a contributing factor as well. The upper reaches of McQueen Branch (near Rd F) also exhibited evidence of degradation in the form of depressed HDMI scores in 2000. However, IBI values suggested better levels of ecological health, especially in 2003 . It is possible that NPDES discharges are contributing to biological degradation in the upper reaches of McQueen Branch, although this factor cannot be separated from the effects of physical habitat degradation.

It is noteworthy that the macroinvertebrate based methods indicated significant degradation in Crouch Branch and Tims Branch, while the fish based IBI indicated only moderate degradation at worst. Fish and macroinvertebrates may respond differently to disturbance as a result of differing ecological or physiological sensitivities (Mount et al. 1984, Yoder and Rankin 1995), with disparities being particularly likely when the level of disturbance is only moderate or slight (Paller 1999). A conservative and prudent approach when IBI and HDMI results disagree is to assume that depressed biotic integrity is likely, although not as severe as when both indices are depressed.

\section{Fourmile Branch IOU}

$|B|$

Sampling for IBI determination in the Fourmile Branch IOU was conducted during 1997, 2000, and 2003. Sites near Road C, Road A-6, and Road A were sampled during all three years (Table 1). Only two (instead of the usual three) $50 \mathrm{~m}$ segments were sampled at Road C during 1997 because of access difficulties. A site near Road 4 was sampled only during 1997 . This area was impounded by beavers in 2000 , converting it from a free flowing stream into a comparatively large, deep pond. The IBI is designed to 
WSRC-TR-2003-00149

Rev. 0

March 27, 2003

analyze fish assemblage structure in streams and would not be expected to produce accurate results in a beaver pond. All IBI sample sites in Fourmile Branch were potentially influenced by SRS waste sites and industrial operations. The reference sites used for statistical analysis of the Fourmile Branch sampling stations were the four in Pen Branch, Meyers Branch, and Mill Creek. The site at Tinker Creek near Kennedy Pond was added in 2003, making a total of five reference sites for analysis of the 2003 data.

Average IBI values at the Fourmile Branch sampling sites during 1997 were 44.0 at Road A, 42.7 at Road A-6, 41.0 at Road C, and 22.0 at Road 4 (Table 5). Only the IBI from Fourmile Branch near Road 4 was significantly lower than the IBIs at the reference sites (reference site mean $=46.0$ ). Comparison of the average IBI from Fourmile Branch near Road 4 with the IBIs calculated from the historical data indicated that it was substantially below any IBI recorded in an undisturbed stream (Figure 2). There were no obvious physical habitat features likely to account for the low IBI near Road 4 (Tables 6 and 7). As previously mentioned, the Road 4 site was subsequently inundated by a beaver dam and could not be sampled during later years. Mean IBI values in Fourmile Branch during 2000 were 42.0 at Road A, 46.0 at Road A-6, and 42.0 at Road C (Table 5 ). These values indicated good biotic integrity and were not significantly different from the IBI values at the control sites. Mean IBI values for the Road A-6 and Road C sites during 2003 (46.7 and 46.0, respectively) were comparable to or higher than during 2000 , but the mean IBI value for Road A declined from 42.0 to 33.3. This was significantly $(P \leq 0.05)$ below the 2003 control site average (47.1). Habitat did not exhibit obvious changes between 2000 and 2003 (Tables 6 and 7) and the habitat analysis performed in conjunction with the 2003 MHSP indicated good habitat quality for this site (Table 12) suggesting that habitat degradation was not responsible for the decline. Similarly, fish tissue analysis generally indicated no increases in contamination between years, suggesting that the decline was not caused by releases from SRS waste sites. At this point, there is no obvious explanation for the IBI decline near Road A. Further sampling may reveal possible causes for this change and whether it is temporary or permanent.

\section{$H A l$ and $K$}

The average $\mathrm{HAl}$ in redbreast sunfish from Fourmile Branch (represented by fish collected near Road A) was 30 (Table 8). This value was lower than in most of the other streams indicating relatively few pathologies (low HAls indicate good health). HAI values for redbreast sunfish from Fourmile Branch were not significantly different than HAI values for redbreast sunfish from the reference sites. Similarly, K (condition) factors for redbreast sunfish from Fourmile Branch (mean of 1.44) were not significantly different than $\mathrm{K}$ factors for redbreast sunfish from the reference sites (Table 8).

$\mathrm{K}$ factors were also calculated for several species of fish (bluehead chub, redbreast sunfish, redfin pickerel, spotted sunfish, flat bullhead, and spotted sucker) collected for tissue contaminant analyses from Fourmile Branch (Table 13). These condition factors were generally within the ranges observed for the same species in other streams. None were unusually low, as might be observed in fish that were in poor health.

\section{Tissue contaminants}

Fish were collected from Fourmile Branch for tissue analysis during 1997 and 2001 (Table 1). During 1997, whole fish composite samples of redbreast sunfish, chain 
WSRC-TR-2003-00149

Rev. 0

March 27, 2003

pickerel, and spotted sunfish were collected near Road A. During 2001, whole fish composite samples of creek chubsucker, redbreast sunfish, and yellow bullhead were collected near Road A13.2 (i.e., near entrance of Fourmile Branch into the Savannah River floodplain swamp), and fish fillet composite samples of redbreast sunfish, bluehead chub, and flat bullhead were collected near Road A.

A number of radioactive constituents were elevated in fish from Fourmile Branch compared with fish from the reference sites (Table 9). Nonvolatile beta, strontium-90, and tritium levels were as high or higher in fish from Fourmile Branch than in fish from any other stream. While not as high as in fish from Lower Three Runs, cesium-137 levels were substantially elevated in comparison with reference stream reaches. There was little difference in the radioactive constituents between the Road A and Road A13.2 sample sites. As with several other SRS streams, radionuclide releases from reactors during the 1960s and 1970s were likely responsible for most of the radioactive constituents found in Fourmile Branch fish (Paller et al. 1999).

Radioactive constituents were measured in fish from the area near Road A during both 1997 and 2000 making it possible to examine changes in radionuclide levels over time. Although this comparison is complicated by the use of different species between years (because of availability) and by the analysis of whole fish during 1997 and fillets during 2000, most constituents differed little between 1997 and 2000. A notable exception was tritium, which declined strongly between 1997 and 2000 (Table 9). Uranium 223/234 exhibited the opposite pattern and was higher in 2001 than in 1997. Reasons for this are uncertain but may be related to the collection of different species between years. Redbreast sunfish, the only species collected during both years, exhibited a decrease in uranium 223/234 over time from $0.007 \mathrm{pc} / \mathrm{g}$ in 1997 to $0.002 \mathrm{pc} / \mathrm{g}$ in 2001.

None of the nonradioactive constituents were elevated in fish from Fourmile Branch compared with fish from the reference sites (Table 10).

\section{HDMI and MHSP}

The HDMI was calculated at four sites on Fourmile Branch during both 1997 and 2000. These included sites near Road F, Road C, Road A, and either Road A-6 or Road A-7 (Table 1). Road A-7 and Road A-6 are only separated by approximately $500 \mathrm{~m}$. In 2003 the MHSP was used to collect macroinvertbrates from streams on the SRS. This represented a departure from earlier macroinvertebrate sampling programs that utilized Hester-Dendy artificial substrates to collect macroinvertebrates. The bioclassification scores generated from the MHSP data and the HDMI scores generated from the HesterDendy data are not directly comparable because of differences in sampling methods, metrics, and scoring scales; however, both are indicators of stream ecological health. MHSP sites on Fourmile Branch included Road 4, Road A-7, and Road A.

During 1997, the HDMI showed a clear trend of increase in a downstream direction, averaging 13.6 at Road F, 18.4 at Road C, 20.4 at Road A-7, and 31.2 at Road $A$ (Table 11). Except for Road A, all values were significantly lower than the control site 
WSRC-TR-2003-00149

Rev. 0

March 27, 2003

Table 13. Condition factors $(K)$ and total lengths $(T L)$ of fish collected for tissue analysis. Species collected in very small numbers are not shown

\begin{tabular}{|c|c|c|c|c|c|c|}
\hline Species & Stream & Station & $\begin{array}{c}\text { Average } \\
\mathrm{K}\end{array}$ & S.E. & $\mathrm{n}$ & $\begin{array}{c}\text { Average } \\
\text { TL }\end{array}$ \\
\hline \multirow[t]{3}{*}{ Bluehead chub } & Pen Branch & Rd. B & 1.19 & 0.047 & 9 & 13.8 \\
\hline & Fourmile Branch & Rd. A & 1.15 & 0.016 & 24 & 10.4 \\
\hline & Pen Branch & Rd. A13.2 & 1.11 & 0.012 & 30 & 8.6 \\
\hline \multirow[t]{12}{*}{ Redbreast sunfish } & Pen Branch & $\mathrm{Rd} . \mathrm{B}$ & 1.58 & 0.043 & 7 & 15.0 \\
\hline & Tinker Creek & Kennedy Pond & 1.63 & 0.035 & 6 & 16.8 \\
\hline & Fourmile Branch & $\mathrm{Rd} . \mathrm{A}$ & 1.67 & 0.040 & 13 & 10.8 \\
\hline & Fourmile Branch & Rd. A & 1.54 & 0.013 & 19 & 10.4 \\
\hline & Fourmile Branch & Rd. A13.2 & 1.78 & 0.030 & 16 & 10.1 \\
\hline & Lower Three Runs & $\mathrm{Rd} . \mathrm{B}$ & 1.73 & 0.073 & 8 & 15.2 \\
\hline & Lower Three Runs & Stinson bridge & 1.94 & 0.046 & 3 & 19.7 \\
\hline & Pen Branch & Rd. A & 1.64 & 0.067 & 10 & 13.1 \\
\hline & Pen Branch & Rd. A13.2 & 1.68 & 0.054 & 10 & 12.3 \\
\hline & Steel Creek & Rd. A & 1.68 & 0.023 & 28 & 11.3 \\
\hline & Steel Creek & Swamp & 1.69 & 0.058 & 6 & 14.4 \\
\hline & Steel Creek & Rd. C & 1.63 & 0.028 & 28 & 10.7 \\
\hline \multirow[t]{2}{*}{ Redfin pickerel } & Tinker Creek & Kennedy Pond & 0.69 & 0.018 & 6 & 19.6 \\
\hline & Fourmile Branch & Rd. A13.2 & 0.66 & 0.048 & 6 & 15.3 \\
\hline \multirow{3}{*}{ Spotted sunfish } & Pen Branch & Rd. B & 1.92 & 0.057 & 18 & 9.9 \\
\hline & Fourmile Branch & Rd. A & 1.98 & 0.058 & 8 & 10.6 \\
\hline & Steel Creek & Swamp & 2.12 & 0.062 & 14 & 11.6 \\
\hline \multirow[t]{3}{*}{ Flat bullhead } & Fourmile Branch & Rd. A & 1.09 & 0.042 & 10 & 14.8 \\
\hline & Lower Three Runs & Rd. B & 1.41 & 0.026 & 4 & 27.7 \\
\hline & Steel Creek & Rd. C & 1.04 & 0.019 & 31 & 12.2 \\
\hline \multirow[t]{3}{*}{ Longnose gar } & Lower Three Runs & Rd. B & 0.26 & 0.002 & 4 & 61.2 \\
\hline & Pen Branch & Rd. A & 0.21 & 0.019 & 4 & 53.4 \\
\hline & Pen Branch & Rd. A13.2 & 0.26 & 0.017 & 3 & 61.0 \\
\hline \multirow[t]{7}{*}{ Spotted sucker } & Fourmile Branch & Rd. A & 0.95 & 0.010 & 5 & 25.8 \\
\hline & Lower Three Runs & HW 125 & 1.01 & 0.089 & 3 & 36.5 \\
\hline & Lower Three Runs & Stinson bridge & 1.01 & 0.030 & 3 & 32.3 \\
\hline & Pen Branch & Rd. A & 0.98 & 0.015 & 11 & 15.1 \\
\hline & Pen Branch & Rd. A13.2 & 1.00 & 0.019 & 5 & 19.2 \\
\hline & Steel Creek & Rd. A & 0.98 & 0.023 & 3 & 37.9 \\
\hline & Steel Creek & Swamp & 1.06 & 0.046 & 4 & 38.9 \\
\hline \multirow[t]{4}{*}{ Largemouth bass } & Lower Three Runs & HW 125 & 1.20 & 0.021 & 2 & 30.9 \\
\hline & Lower Three Runs & Stinson bridge & 1.40 & 0.125 & 10 & 24.3 \\
\hline & Steel Creek & Rd. A & 1.21 & 0.050 & 8 & 31.6 \\
\hline & Steel Creek & Swamp & 1.29 & 0.029 & 9 & 26.4 \\
\hline
\end{tabular}


WSRC-TR-2003-00149

Rev. 0

March 27, 2003

average (31.4). This pattern suggested that the upper reaches of Fourmile Branch were degraded, and that environmental quality improved farther downstream. A somewhat different patterns was observed during 2000 when the only Fourmile Branch site that exhibited an HDMI significantly lower than the control site average (36.0) was Road F. HDMls in Fourmile Branch during 2000 averaged 17.2 at Rd F, 30.0 at Road C, 30.0 at Road A-6, and 32.0 at Road A (Table 11). It is important to recognize that the Road F site, which exhibited the lowest HDMI score during both 1997 and 2000, was upstream of all SRS waste sites. Possible causes of low biotic integrity at this site were low dissolved oxygen levels in water discharged from beaver dams during the summer or naturally occurring high iron levels. These factors may have also acted to depress the HDMI farther downstream.

The MHSP used during 2003 produced ratings of Fair+ for the sites near Road A7 and Road A and Fair- for the site near Road 4 (Table 12). The MHSP indicated that stream quality generally increased in a downstream direction, paralleling previous findings based on the HDMI methodology. While this was not obvious based on the bioclassification scores, it was indicated by trends in the number of EPT taxa (4 upstream, 9 midstream, and 12 downstream) and taxa richness (35 upstream, 29 midstream, and 55 downstream). It is likely that at least some of this increase resulted from improvements in habitat. Habitat scores increased in a downstream direction, from 126 at Road 4 to 152 at Road A-7 and 167 and Road A (Table 12).

As previously described (i.e., Methods and Materials), a procedure was developed to adjust the MHSP bioclassification scores for differences in taxa richness resulting from stream size. With the modified rating system, Road 4 continued to receive a rating of Fair, but the rating for Rd A-7 increased to Good-Fair and rating for Road $A$ increased to Good (Table 12). As shown with data from other streams (e.g., Upper Three Runs), adjustment for stream size increased the accuracy of the MHSP bioclassification scores and, in the case of Fourmile Branch, accentuated the trend of increasing stream quality with progression downstream.

\section{Summary for Fourmile Branch IOU}

Results of the tissue analyses indicated the presence of radioactive contamination in fish from Fourmile Branch. However, HAI, HDMI, and MHSP scores provided no indication that these contaminants affected the ecological integrity of the lower reaches of Fourmile Branch near Road A. IBI values generally supported this conclusion, except in 2003 when the value for the site near Road A was significantly depressed for unidentified reasons. This change does not appear to be attributable to an increase in contamination because most radioactive constituents in fish collected near Road A differed little among years with the exception of tritium which declined over time. In contrast to lower Fourmile Branch, IBI, HDMI, and MHSP values indicated that the upper reaches of Fourmile Branch were degraded near either Road $\mathrm{F}$ or Road 4 during all years of this study. Because Road F was upstream of all SRS waste sites and industrial operations, degradation was probably caused by natural factors such as the release of anoxic water from beaver impoundments, iron leached from wetland soils, or poor physical habitat quality (as indicated by the habitat scores taken with the MHSP samples). However, degradation further downstream near Road 4 cannot be unequivocally attributed to natural factors because previous studies (WSRC 2003) have indicated elevated metal concentrations in this portion of Fourmile Branch as a likely consequence of past industrial operations in $\mathrm{F}$ and $\mathrm{H}$ Areas. In summary, most data 
WSRC-TR-2003-00149

Rev. 0

March 27, 2003

indicate that ecological conditions are near or at normal levels in the lower portion of Fourmile Branch but degraded farther upstream.

\section{Pen Branch IOU}

$|B|$

IBI sample stations in the Pen Branch IOU were located in Pen Branch near Roads C, B, A, and A13.2 and in Indian Grave Branch, a tributary of Pen Branch (Table 1). The sample stations in Indian Grave Branch and in Pen Branch near Roads A and A13.2 were located downstream of SRS waste sites and potentially impacted. The sample stations in Pen Branch near Roads C and B were upstream of all waste sites and considered reference sites along with the sites in Mill Creek and Meyers Branch (1997, 2000, and 2003) and Tinker Creek (2003 only). Pen Branch sites near Roads B and C and the Indian Grave Branch site were sampled during 1997, 2000, and 2003. The Pen Branch site near Road A was sampled in 1997 but was later flooded by a beaver impoundment. As a substitute for the Road A site, a site near Road A13.2 was sampled in 2000 and 2003. Both sites were in the lower reaches of Pen Branch, with the Road A13.2 site being further downstream near the point where Pen Branch enters the Savannah River floodplain swamp.

During 1997, mean IBI values at the potentially impacted Indian Grave Branch and Pen Branch Road A sample sites averaged 44.7 and 45.3, respectively (Table 5). These values were not significantly different from the mean IBI for the four reference sites (i.e., 46.0). In addition, the mean IBI values at these two stations were well within the range of IBI values characteristic of undisturbed streams as indicated by the historical data (Figure 2). The IBI values at the two reference sites within the Pen Branch IOU (Roads B and C) were among the highest recorded during 1997 (48.7 and 47.3, respectively; Table 5).

During 2000, the IBI at the Pen Branch reference sites (Roads C and B) averaged 48.0 and 46.0, reflecting continued high environmental quality at both sites (Table 5). IBI values in Indian Grave Branch and at Pen Branch near Road A13.2 were also quite high, averaging 47.3 and 48.7 , respectively. These values are close to the maximum IBI value of 50 and suggest high environmental quality in both the undisturbed upper reaches of Pen Branch and the downstream reaches that formerly received cooling water discharged from $\mathrm{K}$ Reactor.

IBI values computed from data collected in 2003 generally reflected the same patterns observed during previous years. IBI values remained relatively high at both the undisturbed Road C (42.7) and Road B (46.0) sites and at the potentially impacted Road A13.2 (44.7) and Indian Grave Branch (44.0) sites indicating relatively high biotic integrity throughout the Pen Branch drainage (Table 5). These values were slightly below those measured in 2000 , possibly because of relatively low water levels resulting from drought conditions that prevailed in South Carolina during 2003.

\section{$H A I$ and $K$}

The average HAl for redbreast sunfish from Pen Branch near Road A was 36. The average condition factor (K) was 1.45 (Table 8). Neither HAI nor K values for redbreast sunfish from Pen Branch significantly differed from those for redbreast sunfish from the reference streams indicating that redbreast sunfish from Pen Branch were comparable in health to redbreast sunfish from the reference streams. Similarly, 
WSRC-TR-2003-00149

Rev. 0

March 27, 2003

condition factors for fish collected from Pen Branch for tissue analysis (Table 13) were within the range of condition factors for similar species collected from other streams.

\section{Tissue contaminants}

Fish for tissue analysis were collected from Pen Branch near Roads B and A during 1997 and Road A13.2 during 2001 (Table 1). Road B is an undisturbed site in the upper reaches of Pen Branch, Road $A$ is potentially impacted site in the middle reaches of Pen Branch, and Road A13.2 is a potentially impacted site located near the point where Pen Branch enters the Savannah River swamp. Species collected from each site included bluehead chub, spotted sucker, and redbreast sunfish near Road B; and longnose gar, spotted sucker, and redbreast sunfish near Roads $A$ and A13.2. A piscivorous species was not collected from Pen Branch near Road B because of the scarcity of piscivorous fish at this location.

Several of the radioactive constituents in fish from Pen Branch near Roads $A$ and A13.2 (potentially impacted areas) were high compared with fish from the reference sites; these included strontium-90, tritium, and, at the Road A site only, nonvolatile beta (Table 9). However, most of these constituents were lower than in fish from Fourmile Branch near Road A. Concentrations of all three constituents were substantially lower in fish collected near Road A13.2 than in fish collected near Road A. It is uncertain whether this difference was the result of location (Road A13.2 was farther downstream) or the passage of time (Road A was sampled in 1997 and Road A 13.2 in 2001). Apart from somewhat elevated mercury levels, nonradioactive constituents in fish from Pen Branch at Roads $A$ and $A 13.2$ were no higher than in fish from the reference areas (Table 10).

\section{HDMI and MHSP}

Macroinvertebrate sample sites were located in Pen Branch near Roads C, B, and $A$ and in Indian Grave Branch near the K-Reactor cooling tower. The sites near Roads B and C were reference locations. The sites near Road A and in Indian Grave Branch were potentially impacted. All four sites were sampled during 1997, 2000, and 2003. In 2003 the MHSP was used to collect macroinvertbrates from streams on the SRS. This represented a departure from the 1997 and 2000 macroinvertebrate sampling programs that utilized Hester-Dendy artificial substrates to collect macroinvertebrates. The bioclassification scores generated from the MHSP data and the HDMI scores generated from the Hester-Dendy data are not directly comparable because of differences in sampling methods, metrics, and scoring scales; however, both are indicators of stream ecological health.

HDMI values at the reference sites in Pen Branch (Roads $C$ and $B$ ) were among the highest recorded in this study during both 1997 and 2000. During 1997, HDMI values at the potentially impacted Pen Branch Rd. A and Indian Grave Branch sites (mean of 24.8 and 28.0, respectively) were slightly but not significantly lower than HDMI values at the reference samples sites in Pen Branch and the other streams (30.8-33.6, Table 9). In 2000, HDMI values at the potentially impacted Pen Brach Rd. A and Indian Grave Branch sites (34.8 and 33.2, respectively) were nearly equal to those at the reference sites (33.2-38.0). These HDMI results were in concordance with the IBI results; both indicated that biotic integrity was comparatively high in Pen Branch and Indian Grave Branch. 
WSRC-TR-2003-00149

Rev. 0

March 27, 2003

The MHSP protocol used in 2003 produced bioclassification ratings for Indian Grave Branch and Pen Branch that ranged from Fair to Good (Table 12). The upstreammost sample site in pen Branch (Road C) received the highest rating. When adjusted for stream size (see Methods and Materials), the MHSP bioclassification ratings increased to Good-Fair for all sites except Pen Branch at Road C, which received a rating of excellent. The Habitat scores computed in conjunction with the MHSP protocol were 155 to 160 for the Pen Branch sites and 144 for Indian Grave Branch. These MHSP results are concordant with the HDMI and IBI results, all of which indicate that Pen Branch and Indian Grave Branch are ecologically healthy.

\section{Summary for Pen Branch IOU}

The presence of elevated levels of several radioactive constituents in fish tissues indicated contamination of the portion of Pen Branch downstream from K-Reactor. However, there was no evidence that this contamination has resulted in deleterious ecological effects. Relatively high IBI, HDMI, and MHSP values in Pen Branch near Roads A, A13.2, and in Indian Grave Branch indicated that stream reaches potentially affected by SRS waste sites and discharges compared favorably with biotic integrity in undisturbed streams. Similarly, K and HAl values suggested a lack of deleterious effects upon individual fish in Pen Branch.

\section{Steel Creek IOU}

$|B|$

Fish assemblages in the Steel Creek IOU have been sampled four times (Table 1). In 1996, samples were collected from four locations in Steel Creek (near P Area, near Road C, below the L Lake dam, and near Road A) and from two locations in Meyers Branch (near Old Dunbarton Road and near Road 9). In 1997, fish assemblages were sampled at one sample site in Steel Creek upstream from L Lake (near Road C) and one sample site in Meyers Branch (near Old Dunbarton Road). In 2000 and 2003, fish assemblages were again sampled in Steel Creek near Roads C and $A$ and in Meyers Branch near Old Dunbarton Road. The sample sites in Steel Creek near P Area and near Road C were in the upper reaches of Steel Creek and located downstream from several waste sites and NPDES outfalls. The sample sites below the $L$ Lake dam and near Road A were located farther downstream in the middle reaches of Steel Creek and potentially subject to inputs from SRS waste sites. Meyers Branch sample sites were largely undisturbed.

The IBI at the Steel Creek site near P Area averaged 15.7 in 1996 (Table 5). The IBI slightly downstream near Road C averaged 21.7 in 1996, 32.7 in 1997, 23.3 in 2000 , and 24.7 in 2003. All of these values were significantly lower than the IBIs at the control sites and were below or at the lower end of the range of IBI values calculated for undisturbed streams in the historical data base (Figure 2). The IBI farther downstream at the site located below the L Lake dam averaged 30.3 in 1996. This value was also significantly lower than at the control sites but higher than the average near Road $C$ and $P$ Area. Even farther downstream near Road A, the IBI increased to an average of 36.3 in 1996, 43.3 in 2000, and 36.0 in 2003 . While the 1996 and 2003 values from Road A were relatively low, neither differed significantly from the reference site IBIs, and both were within the range of the IBIs for undisturbed streams in the historical data base.

IBIs for sites in Steel Creek can be compared with IBIs calculated for sites in Meyers Branch (Table 5). The IBI at the site near Old Dunbarton Road averaged 43.7 in 
WSRC-TR-2003-00149

Rev. 0

March 27, 2003

1996, 45.3 in 1997, 46.7 in 2000, and 50.0 in 2003. The IBI at the site near Road 9, sampled in 1996, averaged 40.3. These values were higher than those in Steel Creek (except for Steel Creek near Road A in 2000) and characteristic of undisturbed streams.

In aggregate, the preceding results indicate that biotic integrity was high in Meyers Branch, significantly depressed in upper Steel Creek, and near normal levels in the middle reaches of Steel Creek near Road A. Relatively low biotic integrity in Steel Creek just below the $L$ Lake dam is probably caused by the proximity of $L$ Lake. Hypolimnetic discharge from $L$ Lake during the summer and fall reduces stream temperatures and may have deleterious effects on water quality. The relatively low biotic integrity farther upstream in Steel Creek (near P Area and Road C) may be at least partly habitat related. The banks of upper Steel Creek were eroded and the stream channel was cut more deeply than is typical of most SRS streams. Bank collapse was evident in some areas raising the possibility of intermittent siltation and general habitat instability. Also, the upper portion of Steel Creek was isolated from the rest of Steel Creek by L Lake, which may reduce the number of stream species that can reach upper Steel Creek. The only shiner found in upper Steel Creek in 1996 was the coastal shiner. This species is usually uncommon in small streams but common in L Lake (Paller 1996).

\section{$H A I$ and $K$}

HAls for redbreast sunfish averaged 48 in upper Steel Creek (Road C) and 42 in middle Steel Creek (L Lake dam, Table 8). These values were not significantly different from the HAls measured in the reference streams indicating that pathologies were not unusually numerous among redbreast sunfish collected from Steel Creek. Condition factors $(K)$ for redbreast sunfish from Steel Creek averaged from 1.42 to 1.68 (Table 8). These condition factors were comparable to condition factors in the reference streams (average of 1.57), also suggesting adequate health among redbreast sunfish from Steel Creek.

In addition to the redbreast sunfish collected for HAl analysis, condition factors were calculated for several species collected from Steel Creek for tissue contaminant analysis including redbreast sunfish, spotted sunfish, flat bullhead, spotted sucker, and largemouth bass (Table 13). None of these species exhibited unusually low condition factors in Steel Creek compared with other sites, again suggesting adequate health among Steel creek fish.

\section{Tissue contaminants}

Fish for tissue analysis were collected from three locations in the Steel Creek IOU: Meyers Branch (reference site), Steel Creek near Road B (upstream from L Lake), and Steel Creek near Road A (downstream from L Lake). Species collected included redbreast sunfish, spotted sunfish, and bluehead chub from Meyers Branch; redbreast sunfish, golden shiner, and flat bullhead from Steel Creek near Road C; and redbreast sunfish, largemouth bass, and spotted suckers from Steel Creek near Road A. The radioactive constituents, cesium-137 and, to a lesser degree, strontium-90, were elevated in fish from Steel Creek (both Road A and Road B) compared with fish from the reference sites (Table 9). However, higher cesium-137 levels were observed in fish from Lower Three Runs and higher strontium levels were observed in fish from Fourmile Branch and Pen Branch. None of the nonradioactive constituents were elevated at any of the sample areas in the Steel Creek IOU, although relatively high detection levels for some constituents weakened this conclusion (Table 10). These high detection levels 
WSRC-TR-2003-00149

Rev. 0

March 27, 2003

resulted from the use of different analytical methods than employed with samples collected from the other IOUs (EPD 1997 and 1998).

\section{HDMI and MHSP}

The HDMI was calculated for Steel Creek near Road C and Meyers Branch near Old Dunbarton Road during 1997/1998 and 2000. HDMI values in Meyers Branch, a relatively undisturbed reference site, were high during both sample periods reflecting high environmental quality at this site (Table 11). The mean HDMI for fish from Steel Creek near Road C (upper Steel Creek) in 1997 was 22, which was significantly lower than at the reference sites (which ranged from 31-34). By 2000, the HDMI in Steel Creek near Road $C$ had increased to 31.6 , which no longer significantly differed from the reference sites (33.2-33.8).

In 2003 the MHSP was used to collect macroinvertbrates from SRS streams. This was a departure from earlier macroinvertebrate sampling programs that utilized Hester-Dendy artificial substrates to collect macroinvertebrates. The bioclassification scores generated from the MHSP data and the HDMI scores generated from the HesterDendy data are not directly comparable because of differences in sampling methods, metrics, and scoring scales; however, both are indicators of stream ecological health. MHSP sampling locations in the Steel Creek watershed included Steel Creek near Road C, Meyers Branch near Old Dunbarton Road, and Meyers Branch at Road B-6.2. The latter site was well upstream of Old Dunbarton Road in a first order stream reach. Meyers Branch at Road B-6.2 has not been sampled in the past. It was chosen as a possible reference site because of problems associated with accessing other sampling locations on Meyers Branch (due to security road barricades).

Both Steel Creek and Meyers Branch at Dunbarton Road received MHSP bioclasification ratings of Fair, although the numerical score for Steel Creek (2.5) was considerably higher than the score for Meyers Branch at Dunbarton Road (1.7, Table 12). Meyers Branch at Road B-6.2 received a rating of Poor. This site appeared to be artificially channelized and had a hard clay substrate that provided very poor habitat for benthic invertebrates. The habitat score for this location was only 76, as compared to 140 for Meyers Branch at Dunbarton Road and 168 for Steel Creek. The Poor rating for Meyers Branch at Road B-6.2 is undoubtedly related to the poor habitat and not to SRS operations. When adjusted for the effects of stream size (see Methods and Materials), the rating for Steel Creek near Road $\mathrm{C}$ increased to Good-Fair and the ratings for the other sites remained the same

The comparatively high HDMI and moderate MHSP bioclassification rating for Steel Creek near Road C contrasts with the low IBI from this site. Reasons for this difference between the macroinvertebrate based HDMI and MHSP and fish based IBI are unclear. Fish and macroinvertebrate bioassessments do not always agree because fish and macroinvertebrates respond differently to some environmental disturbances. Mount et al (1984) observed that fish were more sensitive to metal pollution than were macroinvertebrates, but macroinvertebrates were more sensitive to organic pollution than were fish. Yoder and Rankin (1995) observed differences in the rates of recovery of fish and macroinvertebrates from the combined effects of several types of disturbance. Berkman et al. (1986) found that stream fish and invertebrate communities often responded differently to sedimentation and that invertebrates seemed more sensitive to this type of disturbance. The Ohio Department of Natural Resources samples both fish and macroinvertebrates and determines the level of impact based on 
WSRC-TR-2003-00149

Rev. 0

March 27, 2003

the number of taxonomic groups that are degraded (Yoder and Rankin 1999). Based on this logic, a low IBI from Steel Creek indicates environmental degradation, although not as severe as if both fish and macroinvertebrate assemblages were degraded.

\section{Summary for Steel Creek IOU}

Despite improvements in the HDMI and a bioclassification rating of Good-Fair in upper Steel Creek (near Road C), low IBI values suggest some degree of ecological degradation in this area. In contrast, the IBI was higher farther downstream and reached moderate levels in the middle reaches of Steel Creek near Road A. Elevated cesium137 levels in fish from Steel Creek reflect contamination associated with past reactor discharges (Paller et al. 1999). However, it is unlikely that this contamination was responsible for depressed ecological integrity in the upper portion of Steel Creek. More likely explanations include the presence of $L$ Lake and other habitat related factors. HAI and $\mathrm{K}$ data provide further evidence that contamination in Steel Creek was not adversely affecting fish from this stream. Previous calculations of the radiation dose to fish in Steel Creek indicated that radioactive contamination levels were insufficient to produce deleterious effects at the population level (Paller and Dyer 1997).

\section{Lower Three Runs IOU}

\section{$|B|$}

Fish assemblages were sampled near Donora Station in 1997 and 2003 and near Patterson Mill in 2003. IBI values at Donora Station were 38.7 in 1997 and 36.0 in 2003 (Table 5). The IBI at Patterson Mill in 2003 was 37.3. These values were somewhat lower than the averages at the reference sites (42.7-47.3 in 1997 and 42.750.0 in 2003), but the differences were not significant (Table 2). IIBI values for Donora Station and Patterson Mill were also within the range of IBIs for undisturbed streams in the historical data set (Figure 2).

\section{$H A l$ and $K$}

The average HAl for redbreast sunfish from Lower Three Runs near Donora Station was 17 (Table 8). This was the lowest average for any of the sample stations indicating relatively few pathologies among redbreast sunfish from the portion of lower Three Runs represented by the Donora Station sample site. K factors for redbreast sunfish from Donora Station averaged 1.53 and were not significantly different from the $\mathrm{K}$ factors for redbreast sunfish at the reference sites (mean of 1.57) (Table 8).

\section{Tissue contaminants}

Fish collected for tissue analysis from Lower Three Runs included flat bullhead, redbreast sunfish, and longnose gar near Road B in 1997; largemouth bass, redbreast sunfish, and spotted sunfish near Stinson Bridge in 2001; and largemouth bass, redear sunfish, and spotted sunfish near Highway 125 in 2001. The Road B and Stinson Bridge samples were analyzed as whole fish, and the Highway 125 samples were analyzed as fillets.

Average cesium-137 concentrations were higher in fish from the Road B site in Lower Three Runs (average of $3.49 \mathrm{pc} / \mathrm{g}$ ) than in fish from any other site (Table 9). Other radionuclides were present at levels comparable to those in the reference streams. Elevated cesium-137 levels have also been observed in fish from Par Pond (Paller and Wike 1996), the source of most of the discharge near Road B. Cesium-137 contamination of Par Pond and Lower Three Runs was the result of reactor releases that 
WSRC-TR-2003-00149

Rev. 0

March 27, 2003

occurred primarily during the 1960 s and 1970s (Paller et al. 1999). Cesium-137 concentrations were lower in fish collected farther downstream near Stinson Bridge (average of $2.39 \mathrm{pc} / \mathrm{g}$ ) and lowest in fish collected at the downstream-most site near Highway 125 (average of $0.84 \mathrm{pc} / \mathrm{g}$ ). The latter two sites were also sampled four years later than the Road B site raising the possibility that the lower fish tissue cesium-137 levels at these sites may have resulted from the removal of cesium-137 from the ecosystem as a result of physical and ecological processes (Paller et al. 1999). The relatively low cesium-137 levels in fish collected near Highway 125 was not the result of the analysis of fish fillets at this site and whole fish at the other sites since cesium-137 concentrates in muscle tissue rather than bone and most internal organs (Gallegos and Whicker 1971).

Nonradioactive constituents were not elevated in Lower Three Runs fish with the possible exception of mercury, which was moderately elevated in fish collected near Road B (Table 10). Almost all of the Lower Three Runs discharge at Road B is from Par Pond, where elevated mercury levels in fish have been documented previously (Paller and Wike 1996). Ecological conditions in reservoirs may favor the production and mobilization of methylmercury, which is the form of mercury that bioaccumulates most readily (Francis et al. 1998). Mercury contamination resulting from the aerial deposition of mercury is a pervasive problem throughout the Savannah River drainage (EPA 2000).

\section{$H D M I$ and $M H S P$}

Hester-Dendy samples for computation of the HDMI were collected from sites near Donora Station and Stinson Bridge during 2001. HDMI values from these sites averaged 28.0 and 30.4 , respectively (Table 11). These values were somewhat lower than those at the reference sites (averages of 33.2 - 38.0), but the differences were not statistically significant.

In 2003 the MHSP was used to collect macroinvertbrates rather than HesterDendy artificial substrates, which were used during 1997 and 2000. The bioclassification scores generated from the MHSP data and the HDMI scores generated from the Hester-Dendy data are not directly comparable because of differences in sampling methods, metrics, and scoring scales; however, both are indicators of stream ecological health. Both Lower Three Runs sample sites received an MHSP bioclassification rating of Fair (Table 12). When adjusted for stream size (see Methods and Materials), these ratings increased to Fair+ at Donora Station and Good-Fair at Patterson Mill.

\section{Summary for Lower Three Runs IOU}

Elevated cesium-137 levels in fish tissues reflect the presence of contamination in Lower Three Runs. Based on levels in fish tissues, contamination appeared to diminish with increasing distance from Par Pond and may be decreasing over time. Although not significantly different from control site values, both the HDMI and the IBI were slightly depressed in Lower Three Runs. Similarly, the MHSP suggested only a Fair rating for the Lower Three Runs sites. These indications of slight to moderate degradation may be related to the impoundment of Lower Three Runs to form Par Pond, which is approximately $1.5 \mathrm{~km}$ upstream from Donora Station and $6 \mathrm{~km}$ upstream from Pattersons Bridge. Both locations were influenced by discharges from Par Pond and also show evidence of habitat alterations from discharges of large volumes of water related to past operations at SRS. The HAI and $\mathrm{K}$ values indicated no evidence of deleterious effects on the health of individual fish suggesting that the presence of 
WSRC-TR-2003-00149

Rev. 0

March 27, 2003

contaminants is not harming Lower Three Runs fish. In summary, data from lower Three Runs suggests slightly depressed but acceptable biotic integrity in Lower Three Runs and little or no indication of deleterious effects resulting from moderate levels of contamination associated with past reactor releases.

\section{Savannah River and Savannah River Swamp IOUs}

IBI, HDMI, and MHSP

IBI, HDMI, and MHSP protocols have not been developed for the Savannah River nor the Savannah River swamp. Protocols developed for the streams are not suitable for the river and swamp because fish and macroinvertebrate communities in these habitats differ from those in the streams. Therefore, evaluation of the ecological status of the Savannah River IOU was based only on HAI, condition factor (K), and tissue contaminant data.

\section{$H A I$ and $K$}

Redbreast sunfish used for calculation of $\mathrm{HAl}$ and $\mathrm{K}$ values were collected from the portion of the Savannah River swamp located in the Steel Creek area during 1997 (Table 1). This area is more accessible than most portions of the swamp and is likely to be more contaminated than many other areas in the swamp because of the discharge of contaminants from Steel Creek. The average HAI value of 41 was within the range of $\mathrm{HAl}$ values for redbreast sunfish from the reference streams (Table 8) indicating that the number of pathologies and other abnormalities were comparable to those in the reference streams. The average $\mathrm{K}$ value for redbreast sunfish from the Savannah River swamp was 1.89 (Table 8). This value was higher than the average $K$ value from the reference sites (although not significantly higher as indicated by the Kruskal-Wallis test) suggesting good health among the fish collected from the Savannah River swamp.

\section{Tissue contaminants}

Fish for tissue analysis were collected from one location within the Savannah River Swamp, from two locations near the points where SRS streams enter the Savannah River Swamp, and from seven locations in the Savannah River (Table 1). The location within the swamp was within the Steel Creek area as described above (sampled during 1997) and the locations near the swamp were in Fourmile Branch and Pen Branch near the Road A13.2 bridge crossings (both sampled during 2001). Data from the latter two locations have already been discussed in the preceding sections covering Fourmile Branch and Pen Branch; however, they will be discussed again here. Savannah River locations included:

1) the North Augusta Rapids (sampled in 1999 and 2001),

2) just downstream from the Savannah Bluff Lock \& Dam (sampled in 1999),

3) near the mouth of Upper Three Runs (sampled in 1999),

4) near the SRS TNX facility (sampled in 2001),

5) near the mouth of Fourmile Branch (sampled in 1999),

6) near the mouth of Steel Creek (sampled in 1999),

7) near the mouth of Lower Three Runs (sampled in 1999),

8 ) in Coleman Pond (an oxbow or "cut") (sampled in 2001),

9) and near the Highway 301 Bridge (sampled in 1999).

The North Augusta Rapids and Lock \& Dam collection sites were located well upstream from the SRS and did not directly receive contaminants from SRS discharges. However, radio telemetry studies indicate that largemouth bass from SRS streams can 
WSRC-TR-2003-00149

Rev. 0

March 27, 2003

move as far upstream as the Lock and Dam, although such movements are rare (Paller et al. 2001). Movement as far upstream as the North Augusta Rapids is possible (since fish can pass through the Lock and Dam when the lock is open) but probably exceedingly rare. The Highway 301 bridge and Coleman Pond sites are located well downstream of the SRS and likely to be less influenced by SRS contaminants than sites located nearer the SRS. In consideration of these factors, Savannah River collection sites near the SRS have been designated as potentially impacted (PI); Savannah River sites in the North Augusta Rapids have been designated as reference (R); and Savannah River Sites near the Lock and Dam, Coleman Pond, and the Highway 301 bridge have been designated as potentially impacted although the extent of these impacts would be expected to be relatively minimal compared with sites nearer the SRS.

Fish collected from the Savannah River swamp near Steel Creek included two benthic species (yellow bullhead and spotted sucker), two piscivorous species (largemouth bass and bowfin), and three midwater insectivorous species (redear sunfish, redbreast sunfish and spotted sunfish). Several radioactive constituents, particularly cesium-137 and tritium, were moderately elevated in fish collected from the Savannah River swamp compared with fish collected from the reference sites (Table 9). However, these levels were generally comparable to or below those in fish from Lower Three Runs, Fourmile Branch, and Steel Creek (Table 9). Tritium levels in fish from the Savannah River swamp were substantially higher than tritium levels in fish from Steel Creek, probably reflecting the influence of Pen Branch discharge. Discharge from Pen Branch enters Steel Creek through various channels that flow through the Savannah River swamp (Halverson et al. 1997). None of the nonradioactive constituents in fish from the Savannah River swamp near Steel Creek were elevated beyond levels observed in the reference streams (Table 10).

Because of the abundance of fish in the Savannah River swamp near Steel Creek, it was possible to collect and analyze three largemouth bass samples and two redear sunfish samples. Cesium-137 levels in the largemouth bass samples ranged from $0.49-2.44 \mathrm{pci} / \mathrm{g}$, with the lower concentration found in a composite sample of relatively small (under approximately $200 \mathrm{~mm}$ ) fish and the higher concentration found in a composite sample of larger fish. Size related differences in cesium-137 levels in fish are possible because cesium-137 bioaccumulates with age (Rowan and Rasmussen 1994). Cesium-137 samples in the redear sunfish samples ranged between 0.21 and $0.28 \mathrm{pci} / \mathrm{g}$. These data illustrate the range of variation typical of composite samples from the Savannah River swamp.

The samples collected from Fourmile Branch and Pen Branch near Road A13.2 represent fish tissue contaminant levels close to the points where both streams enter the Savannah River swamp. Fish collected from Fourmile Branch included creek chubsuckers, redbreast sunfish, and yellow bullhead. Fish collected from Pen Branch included spotted sucker, redbreast sunfish, and longnose gar. Fish from Fourmile Branch near Road A13.2 exhibited elevated levels of a number of radionuclides including cesium-137, nonvolatile beta, and tritium (Table 9). These levels were generally comparable to those observed farther upstream near Road A. Fish from Pen Branch near Road A13.2 exhibited elevated tritium levels and slightly elevated strontium levels. However, strontium levels were substantially lower than farther upstream in Pen Branch near Road A. It is not known whether this difference was the result of spatial separation between the two sites or the passage of time between the collection of Road A samples in 1997 and Road A13.2 samples in 2001. None of the nonradioactive 
WSRC-TR-2003-00149

Rev. 0

March 27, 2003

constituents were elevated beyond levels observed in fish from the reference streams (Table 10).

Fish collected from the seven sample stations in the Savannah River included one benthic insectivorous species (spotted sucker), two piscivorous species (bowfin and largemouth bass), and three midwater insectivorous species (bluegill, redbreast sunfish, and redear sunfish). Radioactive constituents in fish from the Savannah River were present at lower levels than in fish from the contaminated SRS streams (Table 9). However, cesium-137, strontium, and tritium levels in fish from Savannah River collection sites near Fourmile Branch, Steel Creek, and Lower Three Runs were elevated compared with fish from the reference streams. Nonvolatile beta levels were slightly elevated at several river sites sampled during 1999 but not at sites sampled during 2001. Mercury levels in Savannah River fish were as high or higher than in fish from the SRS streams (Table 10). Other nonradioactive constituents were not elevated in fish from the Savannah River.

\section{Summary for Savannah River IOU}

Fish samples collected at the points where Fourmile Branch and Pen Branch enter the Savannah River swamp indicated the presence of several radiological contaminants. Analysis of fish tissue samples collected from the Savannah River swamp near Steel Creek also indicated the presence of several radioactive contaminants, especially cesium-137 and tritium. However, based on $\mathrm{HAl}$ and $\mathrm{K}$ values, there was no evidence that these constituents were adversely affecting the health of fish from the Savannah River swamp. Several radionuclides were present in Savannah River fish collected near the mouths of contaminated SRS streams; however concentrations were substantially lower than in the fish from the streams themselves. Contaminant concentrations in fish collected from Savannah River sample sites located farther from the SRS were much lower and in many cases were at or near reference site levels.

\section{CONCLUSIONS}

Fish from many SRS streams exhibited evidence of contamination as a result of current or former SRS operations. The most prevalent radiological contaminants were cesium-137 (highest in Lower Three Runs followed by Steel Creek and Fourmile Branch), tritium (highest in Fourmile Branch followed by Pen Branch, and the Savannah River swamp), and strontium (highest in Fourmile Branch followed by Pen Branch). Radiological contaminants were also found in fish collected from the Savannah River near the mouths of contaminated SRS streams; however, contaminant levels were substantially lower than in fish from the streams themselves. Mercury levels were moderately elevated in fish from some streams, particularly Lower Three Runs, and in fish from the Savannah River. Despite the occurrence of contaminants, most SRS streams exhibited comparatively high biotic integrity and minimal levels of pathology among individual fish (e.g., presence of tumors or extreme thinness), indicating that contaminant levels were generally insufficient to cause significant ecological degradation.

A few areas did exhibit ecological degradation, as indicated by low IBI, HDMI, or MHSP scores. All were small tributaries or the smaller upper reaches of larger streams. These areas included Crouch Branch, McQueen Branch, Tims Branch and the upper portions of Fourmile Branch and Steel Creek. Degradation in upper Steel Creek was 
WSRC-TR-2003-00149

Rev. 0

March 27, 2003

probably at least partly the result of habitat (isolation of this portion of the stream by $L$ Lake plus erosion and siltation), and degradation in the upper portion of Tims Branch was probably at least partly related to naturally occurring low oxygen levels and high iron levels (Specht and Paller 1998). Degradation in Crouch Branch, a small tributary of Upper Three Runs, may have been partly habitat related but was also related to the discharge of an NPDES effluent with elevated copper levels (Specht and Paller 1998). Conditions in this stream have improved with improvements in effluent quality. Degradation in the upper portion of McQueen Branch appears to be habitat related, but the possible influence of NPDES discharges cannot be excluded. The cause of degradation in the reach of Fourmile Branch near Road 4 is uncertain but may be related to elevated metal concentrations as a result of past industrial operations.

Repeated sampling of fish and macroinvertebrate assemblages at a number of sites suggested that no streams declined in ecological health and that several (i.e., Fourmile Branch and Crouch Branch) improved over time. Similarly, there was no evidence that fish tissue contaminants increased over time in any stream, and tritium levels in Fourmile Branch fish decreased. Similarly, other studies (Paller et al. 1999) indicate that cesium-137 levels in fish from most SRS waters are decreasing at a rate significantly faster than expected on the basis of physical decay alone.

\section{REFERENCES}

Adams, S.M., A.M. Brown, and R.W. Goede. 1993. A quantitative health assessment index for rapid evaluation of fish condition in the field. Transactions of the American Fisheries Society 122: 63-73.

Angermeier, P.L., and J.R. Karr. 1994. Biological integrity versus biological diversity as policy directives. Bioscience 44:690-697.

Barbour, M.T., J. Gerritsen, B.D. Snyder, J.B. Stribling. 1997. Revision to rapid bioassessment protocols for use in streams and rivers: periphyton, benthic macroinvertebrates, and fish. U.S. Environmental Protection Agency, EPA 841-D-97002. Washington, D.C.

Berra TM, Gunning GE (1972) Seasonal movement and home range of the longear sunfish, Lepomis megalotis (Rafinesque) in Louisiana. Am Midl Nat 88:368-374.

Efron, B. 1982. The jacknife, the bootstrap, and other resampling plans. SIAM, New York.

EPA (United States Environmental Protection Agency). 2000. Total maximum daily load (TMDL) development for total mercury in the middle/lower Savannah River, GA. USEPA Region 4, Atlanta GA.

EPD (Environmental Protection department). 1997. Data summary report for the biological data for Steel Creek. ESH-EMS-960970. Environmental protection Department, Environmental Monitoring Section, Westinghouse Savannah River Company, Aiken, SC.

EPD (Environmental Protection department). 1998. Data summary report for the Upper Three Runs Creek fish sampling and tissue analysis. WSRC-TR-98-00289. 
WSRC-TR-2003-00149

Rev. 0

March 27, 2003

Environmental protection Department, Environmental Monitoring Section, Westinghouse Savannah River Company, Aiken, SC.

Francis DR, Jude DJ, Barres JA. 1998. Mercury distribution in the biota of a Great Lakes estuary: Old Woman Creek, Ohio. J. Great Lakes Res. 24:595-607.

Gatz AJ Jr., Adams SM (1994) Patterns of movement of centrarchids in two warmwater streams in eastern Tennessee. Ecol Freshwat Fish 3:35-48.

Gallegos, A. F.; Whicker, F. W. Radiocesium retention by rainbow trout as affected by temperature and weight. In: Nelson, D. J., ed. Radionuclides in Ecosystems:

Proceedings of the Third National Symposium on Radioecology. Springfield, VA:

National Technical Information Service; U.S. Atomic Energy Commission Symposium

Series; CONF-710501-PI; 1971.

Halverson, N.V. and 20 others. 1997. SRS ecology environmental information document. WSRC-TR-97-0223. Westinghouse Savannah River Company, Aiken, SC.

Jones TA (2001) Seasonal and diel movement of largemouth bass in a South Carolina stream. Unpublished thesis presented to the graduate school of Clemson University, Clemson, SC. 37 pp.

Karr, J.R., K.D. Fausch, P.L. Angermeier, P.R. Yant, I.J. Schlosser. 1986. Assessing biological integrity in running waters: a method and its rationale. Special Publication 5 of the Illinois Natural History Survey.

Klemm, D.J., Q.J. Stober, J.M. Lazorchak. 1993. Fish field and laboratory methods for evaluating the biological integrity of surface waters. U.S. Environmental Protection Agency, EPA/600/R-92/111. Cincinnati, Ohio.

Mount, D.I., N. Thomas, M. Barbour, T. Norberg, T. Roush, R. Brandes. 1984. Effluent and ambient toxicity testing and in-stream community response on the Ottawa River, Lima, Ohio. Permits Division, Washington, D.C., and Office of Research and

Development, Duluth, Minnesota. EPA 600/3-84-080.

Noreen, E. 1989. Computer-intensive methods for testing hypotheses. Wiley.

Paller, M. H. 1992. Stream fisheries characterization study. Westinghouse Savannah River Company, Savannah River Laboratory, Aiken, S.C. WSRC-RP-92-1034.

Paller, M.H. 1994. Relationship between fish assemblage structure and stream order in South Carolina coastal plain streams. Transactions of the American Fisheries Society 123: $150-161$.

Paller, M.H. 1996. L-Lake fish community and water chemistry. WSRC-RP-0163. Savannah River Technology Center. Aiken, SC.

Paller, M.H. 1999. Comparison of fish and macroinvertebrate bioassessments from South Carolina coastal plain streams. . Westinghouse Savannah River Company, Savannah River Laboratory, Aiken, S.C. WSRC-MS-99-00674. 
WSRC-TR-2003-00149

Rev. 0

March 27, 2003

Paller, M.H., R.C. Heidinger, and W.M. Lewis. 1987. Impact of chlorinated secondary and tertiary effluents on warm water fish communities. Water Resources Bulletin 24: 6576.

Paller, M.H., M.J.M. Reichert, J.M. Dean. 1996. Use of fish communities to assess environmental impacts in South Carolina coastal plain streams. Transactions of the American Fisheries Society 125:633-644.

Paller, M.H., and L.D. Wike. 1996. Par Pond fish, water, and sediment chemistry. Westinghouse Savannah River Company, Savannah River Laboratory, Aiken, S.C. WSRC-TR96-0208.

Paller, M.H., and W.L. Specht. 1997. A multimetric index using macroinvertebrate data collected with artificial substrates. Journal of freshwater ecology 12:367-378.

Paller, M.H., and S.A. Dyer. 1999. Biotic integrity of streams in the Savannah River Site integrator operable units. WSRC-TR-00112, Savannah River Technology Center, Aiken, SC.

Paller, M.H., and S.A. Dyer. 2003. Biotic integrity of streams in the Savannah River Site integrator operable units, 1996 to 2001. WSRC-TR-2003-00149, Savannah River National Laboratory, Aiken, SC.

Paller, M.H., J.W. Littrell, and E.L. Peters. 1999. Ecological half-lives of ${ }^{137} \mathrm{Cs}$ in fishes from the Savannah River Site. Health Physics (in press).

Paller, M.H., J.W. Littrell, and S.A. Dyer. 2001. Interim report on the movements of Steel Creek largemouth bass. WSRP-RP-2001-00920. Westinghouse Savannah River Company, Aiken, SC.

Paller, M.H. 2001. Comparison of fish and macroinvertebrate bioassessments from South Carolina coastal plain streams. Aquatic Ecosystem Health \& Management 4:175186.

Plafkin, J.L., M.T. Barbour, K.D. Porter, S.K. Gross, and R.M. Hughes. 1989. Rapid bioassessment protocols for use in streams and rivers: benthic macroinvertebrates and fish. U.S. Environmental Protection Agency, EPA/444/4-89-0001. Washington, D.C.

Rowan, J. R.; Rasmussen, J. B. Bioaccumulation of radiocesium by fish: the influence of physiochemical factors and trophic structure. Canadian Journal of Fisheries and Aquatic Sciences 51:2388-2410; 1994.

SCDHEC (South Carolina Department of Health and Environmental Control). 1998. Standard operating and quality control procedures for macroinvertebrate sampling. Technical Report No. 004-98. Bureau of Water, Division of Water Monitoring, Assessment and Protection, Aquatic Biology Section.

Specht, W.L. 1994. Results of macroinvertebrate sampling conducted at 33 SRS stream locations, July-August 1993. WSRC-TR-0006. . Westinghouse Savannah River Company, Aiken, SC.

Specht, W.L. and M.H. Paller. 1998. Rapid bioassesment methods for assessing stream macroinvertebrate communities of the Savannah River Site. WSRC-TR-95- 
WSRC-TR-2003-00149

Rev. 0

March 27, 2003

0351, Westinghouse Savannah River Company, Savannah River Technology Center, Aiken, SC.

Specht, W.L. and M.H. Paller. 1998. Instream biological assessment of NPDES point source discharges at the Savannah River Site, 1997-1998. WSRC-TR-98-00321, Westinghouse Savannah River Company, Savannah River Technology Center, Aiken, SC.

Specht, W.L. 1999. Qualitative Macroinvertebrate Assessment of Crouch Branch, June 1999. WSRC-TR-99-00410. Westinghouse Savannah River Company, Aiken, SC.

Specht, W.L. and M.H. Paller. 2004. Macroinvertebrate assessments of 22 locations in SRS streams, in support of the Integrator Operable Unit program, July-August 2003. WSRC-TR-2004-00482. Westinghouse Savannah River Company, Aiken, SC.

WSRC (Westinghouse Savannah River Company). 1998a. RCRA facility investigation/remedial investigation work plan for the Upper Three Runs integrator operable unit (U). WSRC-RP-97-447, Rev.0-b. Westinghouse Savannah River Company, Aiken, SC.

WSRC (Westinghouse Savannah River Company). 1998b. Integrator operable unit work plan for the Fourmile Branch (U). WSRC-RP-97-448, Rev.0. Westinghouse Savannah River Company, Aiken, SC.

WSRC (Westinghouse Savannah River Company). 1998c. RCRA facility investigation/remedial investigation work plan for the Steel Creek integrator operable unit (U). WSRC-RP-97-446, Rev.0-b. Westinghouse Savannah River Company, Aiken, SC.

WSRC (Westinghouse Savannah River Company). 1998d. Integrator operable unit work plan for Lower Three Runs (U). WSRC-RP-97-449, Rev.0. Westinghouse Savannah River Company, Aiken, SC.

WSRC (Westinghouse Savannah River Company). 2003. Periodic Report for Fourmile Branch Integrator Operable Unit, WSRC-RP_2002-4139. Rev/ 1. August 2003.

Yoder, C.O. and E.T. Rankin. 1995. Biological response signatures and the area of degradation value: new tools for interpreting multimetric data. Pages 263-286 in W.S. Davis and T.P. Simon (editors). Biological assessment and criteria: tools for water resource planning and decision making. Lewis Publishers, Boca Raton, Florida. 